\title{
RESPOSTA ANTIOXIDATIVA DE PLANTAS DE SOJA AO METAL PESADO CÁDMIO
}

\author{
RENATO RODRIGUES FERREIRA \\ Biólogo
}

Orientador: Prof. Dr. RICARDO ANTUNES DE AZEVEDO

Dissertação apresentada à Escola Superior de Agricultura "Luiz de Queiroz", Universidade de São Paulo, para obtenção do título de Mestre em Agronomia. Área de concentração: Genética e Melhoramento de Plantas.

PIRACICABA

Estado de São Paulo - Brasil

Junho -2000 


\section{ERRATA}

Página 42

Delineamento Experimental

Os experimentos foram inteiramente casualizados com 3 repetições. Os tratamentos também foram realizados em triplicata, sendo que cada parcela foi constituída de um vaso com 15 plantas. As análises enzimáticas da mesma forma, foram realizadas em triplicata para cada repetição. Os resultados foram expressos através das médias e desvio padrão. 
Dados Internacionais de Catalogaçāo na Publicaçāo (CIP)

DIVISÃO DE BIBLIOTECA E DOCUMENTAÇĀO - Campus "Luiz de Queiroz"/USP

Ferreira, Renato Rodrigues

Resposta antioxidativa de plantas de soja ao metal pesado cádmio / Renato

Rodrigues Ferreira. - - Piracicaba, 2000.

$89 \mathrm{p}$.

Dissertação (mestrado) - Escola Superior de Agricultura Luiz de Queiroz, 2000. Bibliografia.

1. Antioxidante 2. Cádmio 3. Estresse vegetal 4. Metal pesado 5. Poluente 6.

Poluição ambiental 7. Soja 8. Toxicidade I. Título

CDD 633.34

"Permitida a copia total ou parcial deste documento, desde que citada a fonte -0 autor" 
"O SER HUMANO VIVENCIA A SI MESMO, SEUS

PENSAMENTOS COMO ALGO SEPARADO DO RESTO DO

UNIVERSO - NUMA ESPÉCIE DE ILUSÃO DE ÓTICA DE SUA

CONSCIÊNCIA. E ESSA ILUSÃo É UMA FORMA dE PRISÃo

QUE NOS RESTRINGE A NOSSOS DESEJOS PESSOAIS, CONCEITIOS E AO AFETO POR PESSOAS MAIS PRÓXIMAS. NOSSA PRINCIPAL TAREFA É AE NOS LIVRARMOS DESSA PRISÃO, AMPLIANDO O NOSSO Ć́rCULO DE COMPAIXÃO, PARA QUE ELE ABRANJA TODOS OS SERES VIVOSS E TODA A

NATUUREZA EM SUA BELEZA. NINGUÉM CONSEGUIRÁ ALCANÇAR COMPLETAMENTE ESSE OBJETIVO, MAS LUTAR PELA SUA REALIZAÇÃo Já É POR SI SÓ PARTE DE NOSSA LIBERAÇÃo E O AIICERCE DE NOSSA SEGURANÇA INTERIOR"。

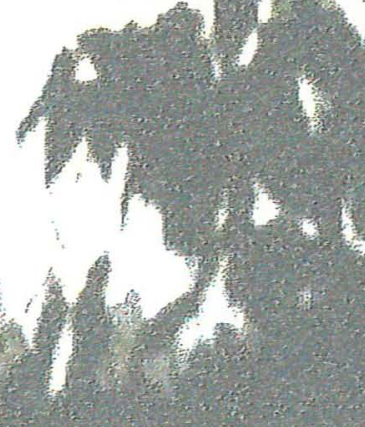


Aos meus pais, José Antonio e Isabel pela dedicação de uma vida inteira direcionada à educação dos filhos, sendo meus exemplos para superat os obstáculos diários e motivos de minha eterna gratidão... A minha esposa Patrícia pelo apoio, força, compreensão $e$ participação em todos os momentos marcantes de minha vida...

\section{OFEREÇO}

Ao meu filho Gabriel, que em sua inocência de criança emana os mais sublimes, puros e verdadeiros sentimentos. Fazendo-me entender o verdadeito sentido da vida $e$ notar, cada vez mais, a presença de Deus em meu lar... 


\section{AGRADECIMENTOS}

À Deus que guiou meus passos e me deu saúde para mais esta caminhada;

Ao Prof. Dr. Ricardo Antunes de Azevedo pela orientação, amizade, confiança, apoio, paciência e humildade, durante a realização deste trabalho. Virtudes encontradas somente nos grandes profissionais, sendo um grande exemplo de conduta profissional no futuro;

À Prof. Dra. Maria Lúcia Carneiro Vieira por acreditar em meu trabalho e me incentivar à ingressar na pós-graduação;

À Prof. Dra. Angela Pierre Vitória pela co-orientação e amizade;

A todos os docentes da ESALQ/USP que colaboraram com minha formação profissional, particionando suas experiências e conhecimentos;

Aos professores, Dr. Natal A. Vello (ESALQ/USP), Dr. Carlos J. Rosseto (IAC) e Dra. Mercedes C. Carrão-Panizzi (EMBRAPA) pelo fornecimento do material vegetal e acesso em suas pesquisas, que muito me auxiliaram;

A todos do Laboratório de Genética Bioquímica de Plantas, especialmente Ricardo F. Fornazier, Guilherme J. G. Pereira, Patricia F. Cardoso, Salete A. Gaziola e Leonardo $O$. Médice, que participaram efetivamente na realização deste trabalho;

À todos os alunos e funcionários da ESALQ/USP que de alguma forma contribuiram para realização deste trabalho, especialmente às bibliotecárias do departamento de Genética da ESALQ/USP e CENA pela paciência, confiança e auxílios prestados; 
À Fundação de Coordenação e Aperfeiçoamento de Pessoal de Nivel Superior (CAPES) pela concessão de bolsa de estudo durante todo o período deste trabalho, sem a qual seria impossivel realizá-lo;

À Fundação de Amparo à Pesquisa do Estado de São Paulo (FAPESP) pelo financiamento desta pesquisa. 


\section{SUMÁRIO}

Página

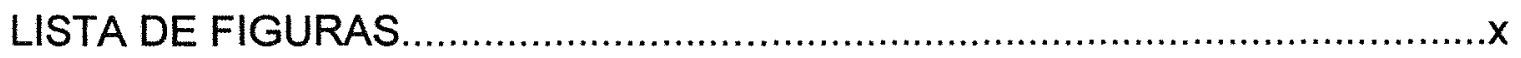

LISTA DE SIGLAS, ABREVIATURAS E SÍMBOLOS.....................................

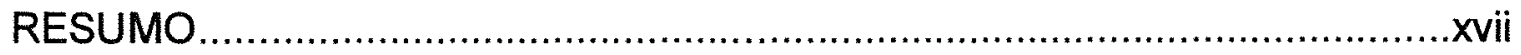

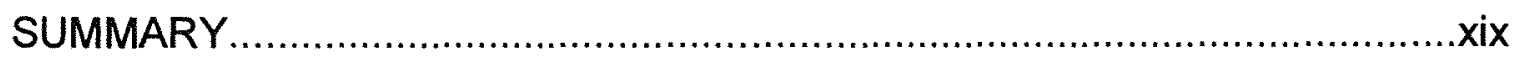

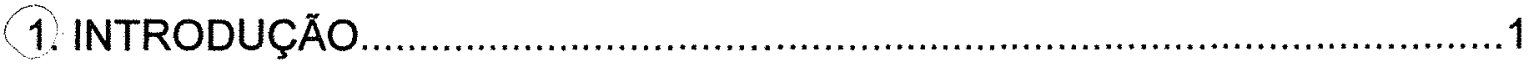

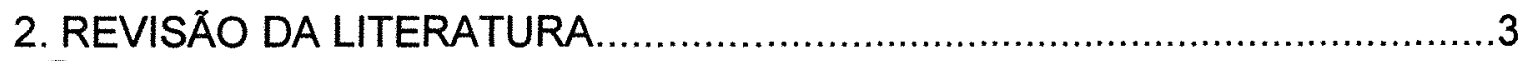

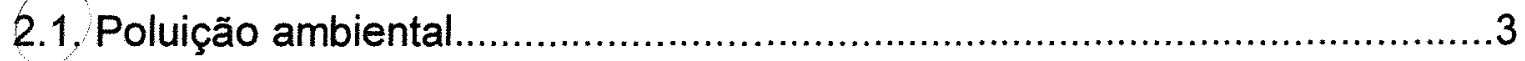

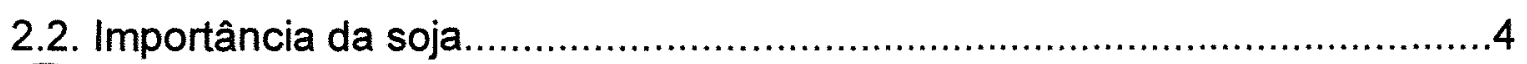

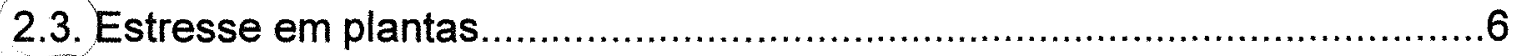

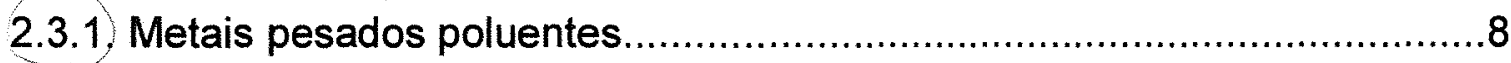

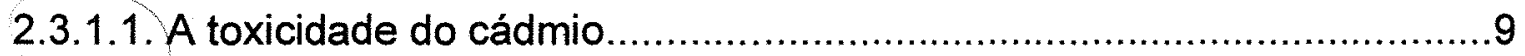

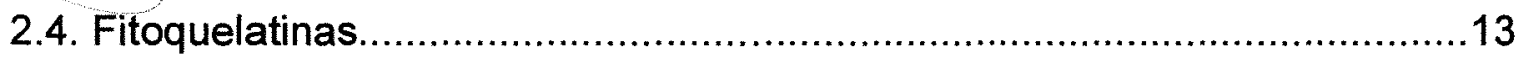

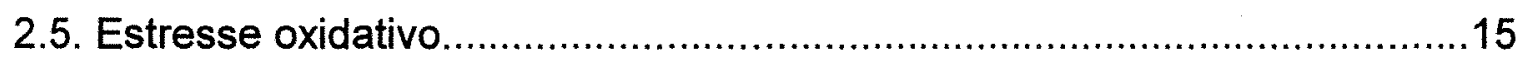

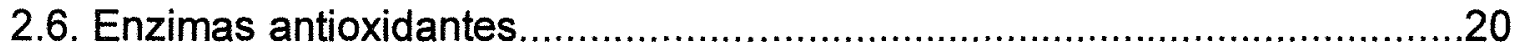

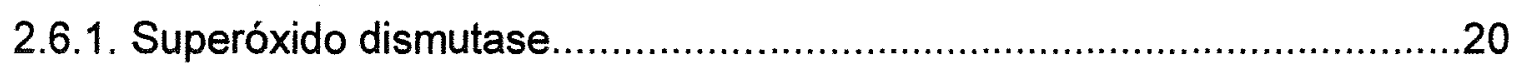

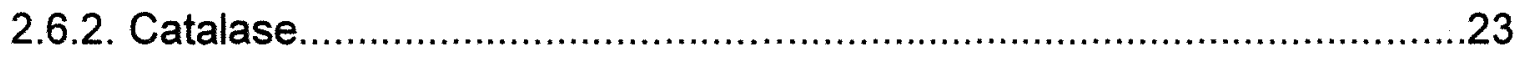

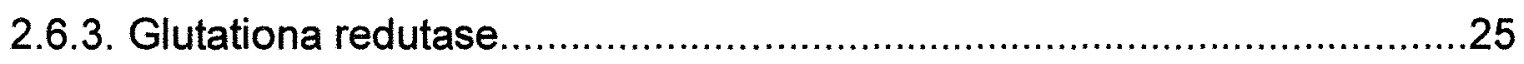

2.7. Atividades de CAT, SOD e GR em plantas.........................................29

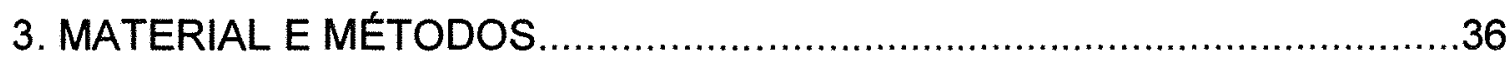

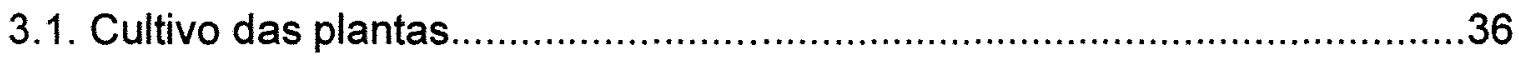

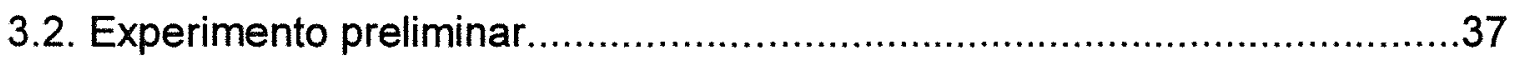

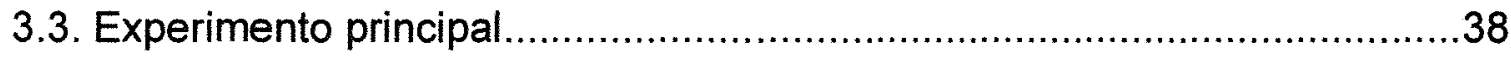

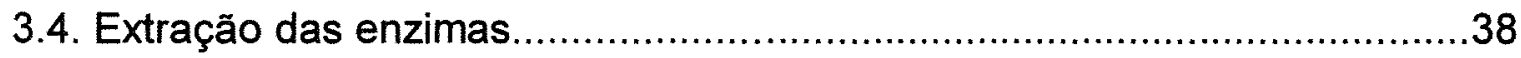




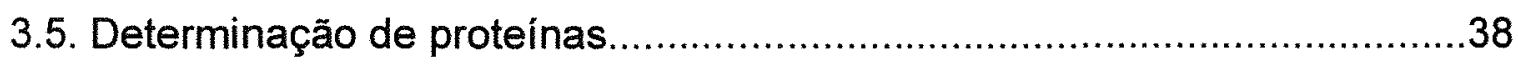

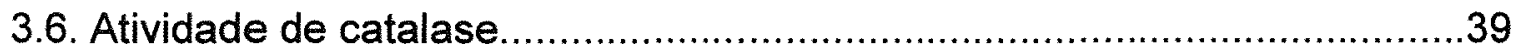

3.6.1. Atividade de CAT em espectrofotômetro..............................................39

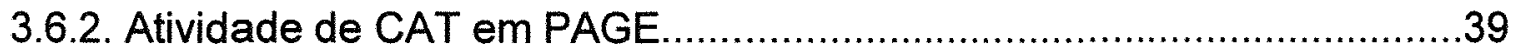

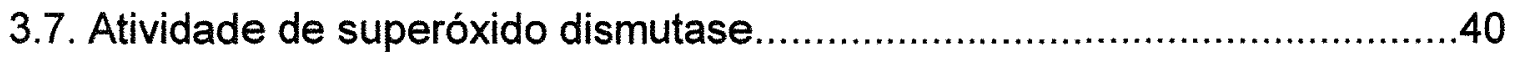

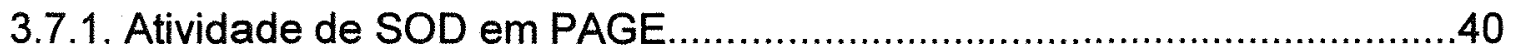

3.7.2. Determinação das isoenzimas de SOD .............................................40

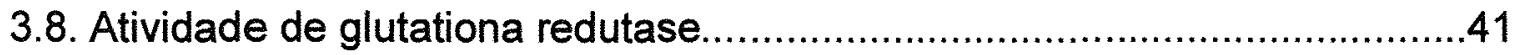

3.8.1. Atividade de GR em espectrofotômetro.............................................41

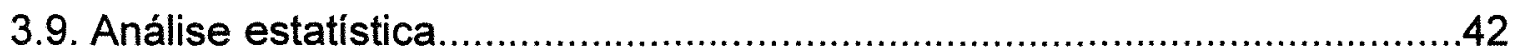

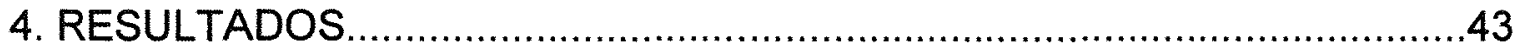

4.1. Determinação da concentração fitotóxica de $\mathrm{Cd}$.......................................43

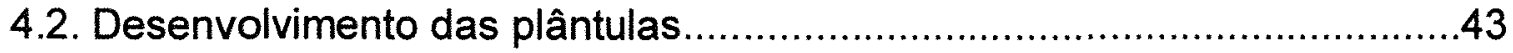

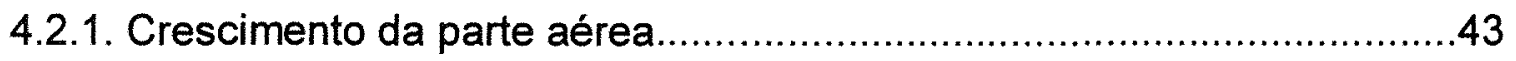

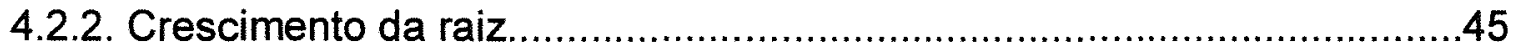

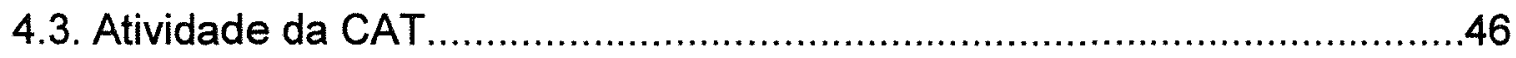

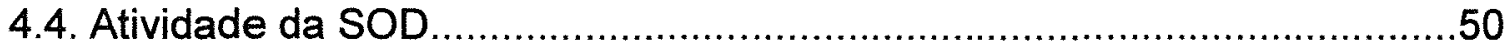

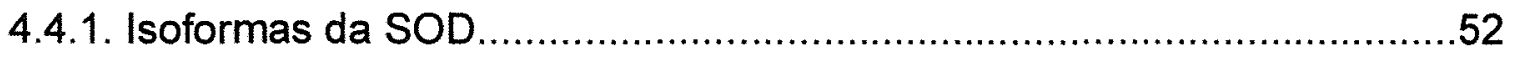

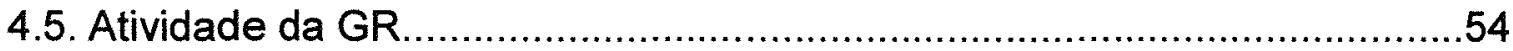

5. DISCUSSÃO

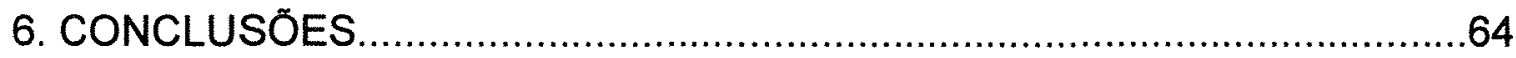

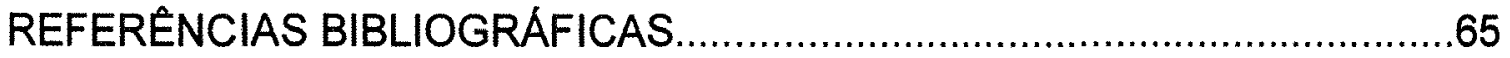




\section{LISTA DE FIGURAS}

Página

1 (A) Adulto de Nezara vinidula e (B) forma verde de Anticarsia gemmatalis (Gazzoni, 1983)

2 Representação das fases da GAS em plantas sob condições de estresse (Lichtenthaler, 1996 e Leshem et al., 1998).

3 Esquema do ciclo água-água nos cloroplastos e a formação de ROS intermediários. No PSI duas moléculas de $\mathrm{O}_{2}$ são reduzidas à $\mathrm{O}_{2}{ }^{-}$-, que é convertido à $\mathrm{H}_{2} \mathrm{O}_{2}$ e $\mathrm{O}_{2}$. $\mathrm{O} \mathrm{H}_{2} \mathrm{O}_{2}$, por sua vez é reduzido à $\mathrm{H}_{2} \mathrm{O}$. Neste processo uma molécula de $\mathrm{O}_{2}$ é reduzida a duas moléculas de $\mathrm{H}_{2} \mathrm{O}$ (Asada, 1999) .18

4 Esquema mostrando iniciadores de ROS e as conseqüências biológicas levando à disfunções biológicas e morte celular (Scandalios, 1993) 19

5 Esquema da atuação da CAT na conversão do $\mathrm{H}_{2} \mathrm{O}_{2}$, produzido pelos processos fotorrespiratórios em plantas $\mathrm{C} 3$ e dismutação dos radicais $\mathrm{O}_{2}{ }^{-}$ pela $\mathrm{Fe}-\mathrm{SOD}$ em $\mathrm{H}_{2} \mathrm{O}$ e $\mathrm{O}_{2}$ 
6 Representação da sintese de $\mathrm{GSH}$, sua redução pela $\mathrm{GR}$ e sua utilização pela GPX para recuperar as $\mathrm{ROOH}$ ou, se $\mathrm{R}=\mathrm{H}$ para remover $\mathrm{H}_{2} \mathrm{O}_{2}$, ou pela GST para desintoxicar xenobióticos ou para a síntese de PCs durante a remoção de íons de metais pesados. As enzimas $\gamma$-EC, GSHS e CGDT também participam neste processo (Lea et al., 1998). .26

7 Mecanismo molecular do sistema fotorredutor do $\mathrm{O}_{2}$ à $\mathrm{H}_{2} \mathrm{O}$ no ciclo água-água e a microcompartimentalização das enzimas participantes, destacando-se o ciclo Halliwell-Asada (Alscher et al., 1998 e Asada, 1999) .28

8 Esquema do cultivo de plântulas de soja em sistema de hidroponia, demonstrando a organização dos vasos no substrato, adequação das plântulas na placa de isopor e sistema de aeração radicular.

9 Efeito do $\mathrm{Cd}$ no crescimento radicular em plântulas de soja submetidas às concentrações de 0 (controle); 0,$5 ; 1 ; 2$ e $5 \mathrm{mM}$ de $\mathrm{CdCl}_{2}$ pelo período de $120 \mathrm{~h}$ de tratamento. 44

10 Efeito do $\mathrm{Cd}$ no desenvolvimento de plântulas de soja que foram crescidas por 5 dias em solução nutritiva e submetidas às concentrações controle $(A)$ e $0,5 \mathrm{mM}$ de $\mathrm{CdCl}_{2}$ (B), por mais $120 \mathrm{~h}$. 44

11 Efeito do $\mathrm{Cd}$ no desenvolvimento da parte aérea de plântulas de soja submetidas à diferentes concentrações de $\mathrm{CdCl}_{2}$. .45

12 Efeito do $\mathrm{Cd}$ no desenvolvimento da raiz de plântulas de soja submetidas à diferentes concentrações de $\mathrm{CdCl}_{2}$. 
13 Atividade específica de CAT ( $\mu \mathrm{mol} / \mathrm{min} / \mathrm{mg}$ prot) em folhas de plântulas de soja submetidas à diferentes concentrações de $\mathrm{CdCl}_{2}$

14 Atividade específica de CAT ( $\mu \mathrm{mol} / \mathrm{min} / \mathrm{mg}$ prot) em raizes de plântulas de soja submetidas à diferentes concentrações de $\mathrm{CdCl}_{2}$.

15 Atividade de CAT em folhas de plântulas de soja submetidas à diferentes concentrações de $\mathrm{CdCl}_{2}$, determinada em PAGE não-desnaturante.

(A) amostra padrão de CAT bovina, (B) $0 \mathrm{~h}-0 \mathrm{mM}$ (controle), (C) $9 \mathrm{~h}$ $0 \mathrm{mM},(\mathrm{D}) 9 \mathrm{~h}-0,5 \mathrm{mM},(\mathrm{E}) 18 \mathrm{~h}-0 \mathrm{mM},(\mathrm{F}) 18 \mathrm{~h}-0,5 \mathrm{mM},(\mathrm{G}) 24 \mathrm{~h}$ $0 \mathrm{mM},(\mathrm{H}) 24 \mathrm{~h}-0,5 \mathrm{mM}$, (I) $48 \mathrm{~h}-0 \mathrm{mM}$ e (J) $48 \mathrm{~h}-0,5 \mathrm{mM}$ 49

16 Atividade de CAT em raízes de plântulas de soja submetidas à diferentes concentrações de $\mathrm{CdCl}_{2}$, determinada em PAGE não-desnaturante.

(A) amostra padrão de CAT bovina, (B) $0 \mathrm{~h}-0 \mathrm{mM}$ (controle), (C) $9 \mathrm{~h}$ $0 \mathrm{mM}$, (D) $9 \mathrm{~h}-0,5 \mathrm{mM}$, (E) $18 \mathrm{~h}-0 \mathrm{mM}$, (F) $18 \mathrm{~h}-0,5 \mathrm{mM},(\mathrm{G}) 24 \mathrm{~h}$ $0 \mathrm{mM},(\mathrm{H}) 24 \mathrm{~h}-0,5 \mathrm{mM}$, (I) $48 \mathrm{~h}-0 \mathrm{mM}$ e (J) $48 \mathrm{~h}-0,5 \mathrm{mM}$.

17 Atividade de SOD em folhas de plântulas de soja submetidas à diferentes concentrações de $\mathrm{CdCl}_{2}$, determinada em PAGE não-desnaturante. (A) amostra padrão de SOD de figado bovino, (B) $0 \mathrm{~h}-0 \mathrm{mM}$ (controle), (C) $9 \mathrm{~h}-0 \mathrm{mM}$, (D) $9 \mathrm{~h}-0,5 \mathrm{mM}$, (E) $18 \mathrm{~h}-0 \mathrm{mM}$, (F) $18 \mathrm{~h}-0,5 \mathrm{mM}$, (G) $24 \mathrm{~h}-0 \mathrm{mM}$, (H) $24 \mathrm{~h}-0,5 \mathrm{mM}$, (I) $48 \mathrm{~h}-0 \mathrm{mM}$ e (J) $48 \mathrm{~h}-0,5 \mathrm{mM} \ldots . . .51$ 
18 Atividade de SOD em raízes de plântulas de soja submetidas à diferentes concentrações de $\mathrm{CdCl}_{2}$, determinada em PAGE nãodesnaturante. (A) amostra padrão de SOD de fígado bovino, (B) $0 \mathrm{~h}-0 \mathrm{mM}$ (controle), (C) $9 \mathrm{~h}-0 \mathrm{mM}$, (D) $9 \mathrm{~h}-0,5 \mathrm{mM}$, (E) $18 \mathrm{~h}$ $0 \mathrm{mM},(\mathrm{F}) 18 \mathrm{~h}-0,5 \mathrm{mM},(\mathrm{G}) 24 \mathrm{~h}-0 \mathrm{mM},(\mathrm{H}) 24 \mathrm{~h}-0,5 \mathrm{mM}$, (I) $48 \mathrm{~h}-0 \mathrm{mM}$ e (J) $48 \mathrm{~h}-0,5 \mathrm{mM}$.

19 Caracterização das isoenzimas de SOD presentes em folhas de soja em PAGE não-desnaturante. $\operatorname{Em}(\mathrm{A})$ controle padrão de atividade, (B) controle $+\mathrm{H}_{2} \mathrm{O}_{2}$ e (C) controle $+\mathrm{KCN}$ .53

20 Caracterização das isoenzimas de SOD presentes em raízes de soja em PAGE não-desnaturante. Em (A) controle padrão de atividade, (B) controle $+\mathrm{H}_{2} \mathrm{O}_{2}$ e (C) controle $+\mathrm{KCN}$. .54

21 Atividade especifica de GR ( $\mu \mathrm{mol} / \mathrm{min} / \mathrm{mg}$ prot) em folhas de plântulas de soja submetidas à diferentes concentrações de $\mathrm{CdCl}_{2}$ .55

22 Atividade especifica de GR ( $\mu \mathrm{mol} / \mathrm{min} / \mathrm{mg}$ prot) em raizes de plântulas de soja submetidas à diferentes concentrações de $\mathrm{CdCl}_{2}$ 


\section{LISTA DE SIGLAS, ABREVIATURAS E SIMBOLOS}

$\gamma$-EC $=\gamma$-glutamil-cisteína sintetase

${ }^{1} \mathrm{O}_{2}=$ oxigênio "singlet"

AFS = espaços livres aparentes

$\mathrm{Al}=$ alumínio

APX $=$ ascorbato peroxidase

As $A=$ ascorbato

$\mathrm{BSA}=$ soro albumina bovina

BSO = butionina sulfoximina

$\mathrm{C}=$ carbono

$\mathrm{CAT}=$ catalase

$\mathrm{Cd}=$ cádmio

$\mathrm{CdCl}_{2}=$ cloreto de cádmio

CGDT $=\gamma$-glutamato-cisteína dipeptidil transferase

Co $=$ cobalto

$\mathrm{CO}_{2}=$ dióxodo de carbono

$\mathrm{Cr}=$ crômio

$\mathrm{Cu}=$ cobre

$\mathrm{Cu} / \mathrm{Zn}-\mathrm{SOD}=$ cobre/zinco superóxido dismutase

$\mathrm{DHA}=$ deidroascorbato

DHAR = deidroascorbato redutase

DTNB = 5,5"- ditiobis (2- ácido nitrobenzóico)

DTPA = ácido dietiltriamina pentacético

DTT = ditiotreitol

EDTA = ácido etileno diamino tetracético 
$F A D=$ flavina adenina dinucleotideo

$\mathrm{Fd}=$ ferredoxina

$\mathrm{Fe}=$ ferro

$\mathrm{FeCl}_{3}=$ cloreto férrico

$\mathrm{Fe}-\mathrm{SOD}=$ ferro superóxido dismutase

$\mathrm{FNR}=$ ferredoxina-NADP ${ }^{+}$oxidorredutase

GAS = síndrome de adaptação geral

GPX = glutationa peroxidase

$\mathrm{GR}$ = glutationa redutase

$\mathrm{GSH}=$ glutationa reduzida

GSHS = glutationa sintetase

GSSG = glutationa oxidada

GST = glutationa-S-transferase

$\mathrm{H}_{2} \mathrm{O}=$ água

$\mathrm{H}_{2} \mathrm{O}_{2}=$ peróxido de hidrogênio

$\mathrm{Hg}=$ mercúrio

$\mathrm{K}_{3} \mathrm{Fe}\left(\mathrm{CN}_{6}\right)=$ ferricianeto de potássio

$\mathrm{KCN}=$ cianeto de potássio

LHC II / PS II = "Light harvesting complex II and Photosystem II"

MBPs = proteínas ligadas à metais

MDA = radical monodeidroascorbato

MDAR = monodeidroascorbato redutase

$\mathrm{Mn}=$ manganês

Mn-SOD = manganês superóxido dismutase

Mo $=$ molibdênio

mRNA $=$ RNA mensageiro

$N=$ nitrogênio

$\mathrm{NADPH}=$ nicotinamida adenina dinucleotídeo fosfato reduzida

NBT = nitro blue tetrazolium

$\mathrm{Ni}=$ niquel 
$\mathrm{O}_{2}=$ oxigênio molecular

$\mathrm{O}_{2}{ }^{\circ}-=$ radical superóxido

$\mathrm{O}_{3}=$ ozônio

$\mathrm{OH}^{*}=$ radical hidroxila

$\mathrm{PA}=$ persulfato de amônia

PAGE = eletroforese em gel de poliacrilamida

$\mathrm{Pb}=$ chumbo

$P C s$ = fitoquelatinas

PGRs = reguladores de crescimento de plantas

$P O X=$ peroxidase

PSII = fotossistema $\|$

$P S I=$ fotossistema I

PVPP = polivinil polipirrolidona

RNA = ácido ribonucléico

$\mathrm{ROOH}=$ hidroperoxidases fosfolipidicas

ROS = espécies reativas de oxigênio

RUBISCO = ribulose-1,5-bisfosfato carboxilase/oxigenase

$S A=$ ácido salicílico

$\mathrm{SF}=$ fator do estroma

$\mathrm{SO}_{2}=$ dióxido de enxofre

$S O D=$ superóxido dismutase

TEMED $=\mathrm{N}, \mathrm{N}, \mathrm{N}^{\prime}, \mathrm{N}^{\prime}$ - tetrametilenodiamina

$\mathrm{V}=$ vanádio

$\mathrm{Zn}=$ zinco 


\title{
RESPOSTA ANTIOXIDATIVA DE PLANTAS DE SOJA AO METAL PESADO CÁDMIO
}

\author{
Autor: RENATO RODRIGUES FERREIRA
}

Orientador: Prof. RICARDO ANTUNES DE AZEVEDO

\section{RESUMO}

Entre os variados tipos de poluentes ambientais, os metais pesados estão presentes e destacam-se por sua toxicidade tanto para plantas como para animais e aos seres humanos. Dentre os metais pesados, o cádmio (Cd) é um dos que tem sua concentração aumentada no ambiente nos últimos anos. Pouca informação está disponivel na literatura com referência a resposta antioxidante de plantas ao efeito deste metal. Neste sentido, o objetivo deste trabalho foi de investigar este aspecto em soja. Para isto, plântulas de soja foram crescidas em sistema de hidropônico contendo solução nutritiva e com diferentes concentrações de Cd $(0 ; 0,01$ e 0,5 mM) por um período de $120 \mathrm{~h}$. Raizes e folhas foram analisadas para atividades de catalase, glutationa redutase e superóxido dismutase. Apesar de um efeito claro do Cd no crescimento, as atividades de catalase e superóxido dismutase não variaram significativamente em raízes e folhas nas concentrações testadas. Glutationa 
redutase também não mostrou variação em atividade em folhas, contudo em raizes um aumento expressivo na atividade foi observado na concentração de $0,5 \mathrm{mM} \mathrm{Cd}$. As isoenzimas de catalase e superóxido dismutase foram caracterizadas em PAGE não-desnaturante. A coloração para atividade de superóxido dismutase revelou a existência de sete bandas em folhas e oito em raízes, correspondendo a Mn-SOD e Cu/Zn-SOD. Nenhuma isoforma do tipo Fe-SOD foi observada. Para catalase, apenas uma banda comum de atividade em folha e raiz foi observada. Apesar de não ter sido observada variações significativas nas folhas, em raízes no tratamento de $0,5 \mathrm{mM} \mathrm{Cd}$ um ligeiro aumento de atividade de catalase foi observado. Estes resultados sugerem que em soja, glutationa redutase responde ao $\mathrm{Cd}$ em raizes, possivelmente para produzir glutationa reduzida via o ciclo Halliwell-Asada para ser utilizada na síntese de fitoquelatinas e/ou como uma resposta à geração de espécies reativas de oxigênio induzidas pelo $\mathrm{Cd}$. 


\title{
ANTIOXIDATIVE RESPONSES OF SOYBEAN PLANTS TO THE HEAVY METAL CADMIUM
}

\author{
Author: RENATO RODRIGUES FERREIRA
}

Supervisor: Prof. RICARDO ANTUNES DE AZEVEDO

\section{SUMMARY}

Soybean (Glycine max L.) seedlings were grown in a hydorponic system containing nutrient solution with varyng concentrations $(0 ; 0,01$ e 0,5 $\mathrm{mM}$ ) of cadmium (Cd) for a $120 \mathrm{~h}$ period. Roots and leaves were analysed for catalase, glutathione reductase and superoxide dismutase activities. Although a clear effect of $\mathrm{Cd}$ on plant growth was observed, the activities of catalase and superoxide dismutase were not altered significantly in roots or leaves at all concentrations tested. Glutathione reductase did not exhibit any variation in activity in leaves, however, in roots an increase in activity was observed at 0,5 $\mathrm{mM} \mathrm{Cd}$. Catalase and superoxide dismutase isoenzymes were further characterized by analysis in non-denaturing PAGE. Activity staining for superoxide dismutase revealed seven isoenzymes in leaves and eight isoenzymes in roots, corresponding to Mn-SOD and Cu/Zn-SOD. No Fe-SOD isoenzymes were observed. For catalase, one band of activity was observed in 
leaves and roots. Although no significant variation was observed in leaf tissue, in roots the $0,5 \mathrm{mM}$ Cd treatment exhibited a slight increase in catalase activity. The results suggest that in soybean, glutathione reductase responds to $\mathrm{Cd}$ in rrots, possibly to produce reduced glutathione via the Halliweell-Asada cycle to be used in the synthesis os phytochelatins and/or as a response to the generation os reactive oxygen species induced by $\mathrm{Cd}$. 


\section{INTRODUÇÃO}

O contínuo aumento populacional, crescente urbanização e industrialização, agravaram de modo sensível a produção de resíduos tóxicos no ambiente, como o caso dos metais pesados, originando à partir disso grandes impactos ambientais e preocupações ecológicas e sanitárias (Melo et al., 1997).

O cádmio (Cd) é um dos metais pesados mais tóxicos para as plantas e animais, sendo aquele que tem apresentado as mais altas taxas de emissão para o ambiente nas últimas décadas, devido a sua utilização na produção de ligas, plásticos, pigmentos, indústria automobilística, baterias, fertilizantes fosfatados, pesticidas, etc (Prasad, M.N.V. 1997).

Em solos não contaminados, o Cd encontra-se em concentrações que variam de 0,01 a $0,7 \mathrm{mg} / \mathrm{kg}$, podendo ser aumentadas pela utilização de insumos agrícolas que contenham 0 elemento ou rejeitos industriais contaminados, o que pode possibilitar a introdução do metal na cadeia alimentar mediante a absorção pelas plantas (Nascimento \& Pereira, 1997).

As plantas, de modo geral, não são capazes de regular a absorção de metais pesados, de tal forma que estando estes disponiveis e em contato com as raízes, serão absorvidos, sendo ou não necessários ao pleno desenvolvimento das mesmas. A absorção, distribuição e efeitos do $\mathrm{Cd}$ em diversos processos metabólicos parecem ser controlados por diversos fatores, tais como espécies elou variedades, água, estado nutricional, estágio de desenvolvimento e tempo de exposição ao metal (Melo et al., 1997). 
Muitas pesquisas têm sido realizadas mostrando que as plantas respondem para os mais diversos fatores estressores pela indução de um sistema antioxidante de defesa, representado por componentes não enzimáticos (glutamina, ascorbato, carotenóides, etc) e enzimáticos (enzimas antioxidantes) (Foyer et al., 1994), que funcionam para prevenir ou limitar os efeitos deletérios às células causados por espécies reativas de oxigênio (ROS), como rompimento das membranas, danos ao DNA e perda de atividades protéicas (Rice-Evans et al., 1991). Dentre as principais enzimas antioxidantes vegetais, podem-se destacar a catalase (CAT) (Willekens et al., 1995), glutationa redutase (GR) (Alscher, 1989) e a superóxido dismutase (SOD) (Scandalios, 1993).

As plantas também respondem aos metais pesados sintetizando uma classe de polipeptídios denominados fitoquelatinas (PCs), que parecem ser ubíquos para as plantas superiores e também estão presentes em algumas espécies de algas e leveduras (Howden et al., 1995).

Em teoria, a análise da indução e acumulação de proteínas antioxidantes e outras proteinas de defesa em plantas, podem fornecer um eficiente meio de monitorar o efeito dos poluentes no meio ambiente.

Os estudos de estresses em plantas estão bastante avançados em relação aos gases poluentes, porém para os metais pesados pouco se sabe à respeito da relação de seus efeitos com as respostas das plantas pelos sistemas antioxidantes. Tendo em vista este fato, procuramos levantar dados relacionando a soja, uma das culturas agricolas de maior expressão na economia brasileira, aos efeitos do $\mathrm{Cd}$ utilizando-se a variedade IAC-100 resistente à pragas no campo (Rosseto et al., 1995). 


\section{REVISÃO DA LITERATURA}

\subsection{Poluição ambiental}

A atividade humana é geradora permanente de residuos. Nos primórdios da humanidade, os resíduos se limitavam às sobras alimentares, aos dejetos humanos e aos restos de uma agricultura insipiente, sendo que a própria natureza cuidava de processar sua reciclagem (Melo et al., 1997).

Com o aumento populacional, as pessoas passaram a se concentrar em grandes centros urbanos e a necessidade de produzir quantidades cada vez maiores de alimentos e o aparecimento de indústrias com os mais diferentes objetivos, agravaram de modo significativo a produção de resíduos altamente tóxicos (produtos orgânicos $e$ inorgânicos) que passaram a se acumular em quantidade proporcional ou superior ao crescimento urbano, originando grandes impactos ambientais e preocupações ecológicas e sanitárias (Melo et al., 1997).

Dentre esses resíduos, os metais pesados têm sido considerados os principais poluentes ambientais e suas bioconcentrações em plantas e ervas daninhas, na agricultura, horticultura e silvicultura e em macrófitas aquáticas, são de especial preocupação e interesse ao bem estar humano (Prasad, M.N.V. 1997).

De todos os metais pesados poluentes, o Cd é um dos mais tóxicos (Chen \& Kao, 1995) para os seres humanos, animais e plantas sendo, entre esses elementos, o que tem apresentado as mais altas taxas de emissão para o ambiente nas últimas décadas (Nascimento \& Pereira, 1997). 
Em plantas, pesquisas têm sido conduzidas quase que exclusivamente para análises do conteúdo total de $\mathrm{Cd}$ dentro das sementes, visto que pode ser um potencial risco para os consumidores. São poucos os trabalhos relatando os efeitos que os poluentes metálicos podem exercer no metabolismo e desenvolvimento das plantas (Malan \& Farrant, 1998).

A soja, devido a seu alto valor nutritivo, tem tido aumentada sua utilização nos países desenvolvidos como uma fonte de alimento (Gupta, 1983). Esta espécie passa a ser importante para se avaliar o impacto de metais poluentes na produção de sementes (Malan \& Farrant, 1998) e desenvolvimento do vegetal, como também as alterações metabólicas e fisiológicas envolvidas no processo.

\subsection{Importância da soja}

A soja é uma planta originária da Ásia oriental (norte da China), diplóide $(2 n)$ com 40 cromossomos, autógama e anual, com taxa de autopolinização acima de $99 \%$, embora abelhas visitem suas flores em busca de néctar (Kiang \& Gorman, 1983). Pertence à família Leguminosae, subfamilia Papilionoideae, tribo Phaseoleae, subtribo Phaseolinae (Glycininae), gênero Glycine L., subgênero soja e à espécie Glycine max (L.) Merrill (Pinheiro, 1993).

Considerando o estado nutricional das populações dos países da América do Sul, como exemplo o Brasil onde $32 \%$ da população vive na mais absoluta miséria (Oliveira et al., 1996), o consumo de soja poderia ser amplamente promovido e incentivado. A soja é uma importante alternativa para o problema da desnutrição, possuindo $40 \%$ de proteínas, $20 \%$ de lipidios (Kiang \& Gorman, 1983), vitaminas e minerais. Além disto, tem potencial na prevenção e tratamento de doenças cardiacas (Carrão-Panizzi et al., 1998) e câncer, reduzindo a incidência de carcinoma de próstata e de mama em pessoas que a utilizam regularmente na dieta, além de causar redução dos 
efeitos problemáticos da menopausa (Carrão-Panizzi \& Kitamura, 1995 e Carrão-Panizzi, 1998).

No Brasil, a produção de soja concentra-se, principalmente, na região Centro-Sul (São Paulo, Paraná, Santa Catarina e Rio Grande do Sul) e região Centro-Oeste (Minas Gerais, Goiás, Mato Grosso do Sul, Mato Grosso e Distrito Federal) (EMBRAPA SOJA, 1999).

Atualmente, o Brasil é o segundo maior país produtor de soja do mundo, sendo superado apenas pelos EUA, produzindo cerca de $20 \%$ da produção mundial (Margarido \& Souza, 1998). Este incremento na produção resultou dos vários incentivos governamentais, como creditícios, pesquisas, apoio técnico e demanda do mercado externo de farelo de soja (EMBRAPA SOJA, 1999).

Além disso, a soja atualmente é o principal produto na pauta das exportações brasileiras, sendo responsável por $10 \%$ do total de exportações e $30 \%$ das exportações de produtos agropecuários. Considerando-se a produção da safra $1997 / 98$, foram exportados $30 \%$ da soja produzida no País, sendo $55 \%$ do farelo e $35 \%$ do óleo produzido naquele ano (Margarido \& Souza, 1998).

Dentre as variedades de soja cultivadas, a IAC-100 é de especial interesse, pois além de apresentar as características relativas à saúde e nutrição já descritas, ela também apresenta resistência às principais pragas que parasitam a cultura, como a Anticarsia gemmatalis e Nezara viridula (Panizzi et al., 1986; Rosseto, 1989; Rosseto et al., 1989 e 1995) (Fig. 1).

O manejo de pragas com cultivares resistentes é ideal, pois além de gratuito, não é poluente, não causa desequilibrio biológico, é de fácil adoção e não interfere com outras práticas agrícolas (Fernandes et al., 1994).

Como no caso das pragas citadas, inúmeros outros fatores podem afetar os organismos vivos, especialmente as plantas, que diferentemente dos animais, são sedentárias e estão mais sujeitas às variações das condições ambientais (Florijn et al., 1993), que as conduzem a uma situação de estresse 
que pode causar danos fisiológicos irrecuperáveis ou até mesmo a morte da planta (Lichtenthaler, 1996).

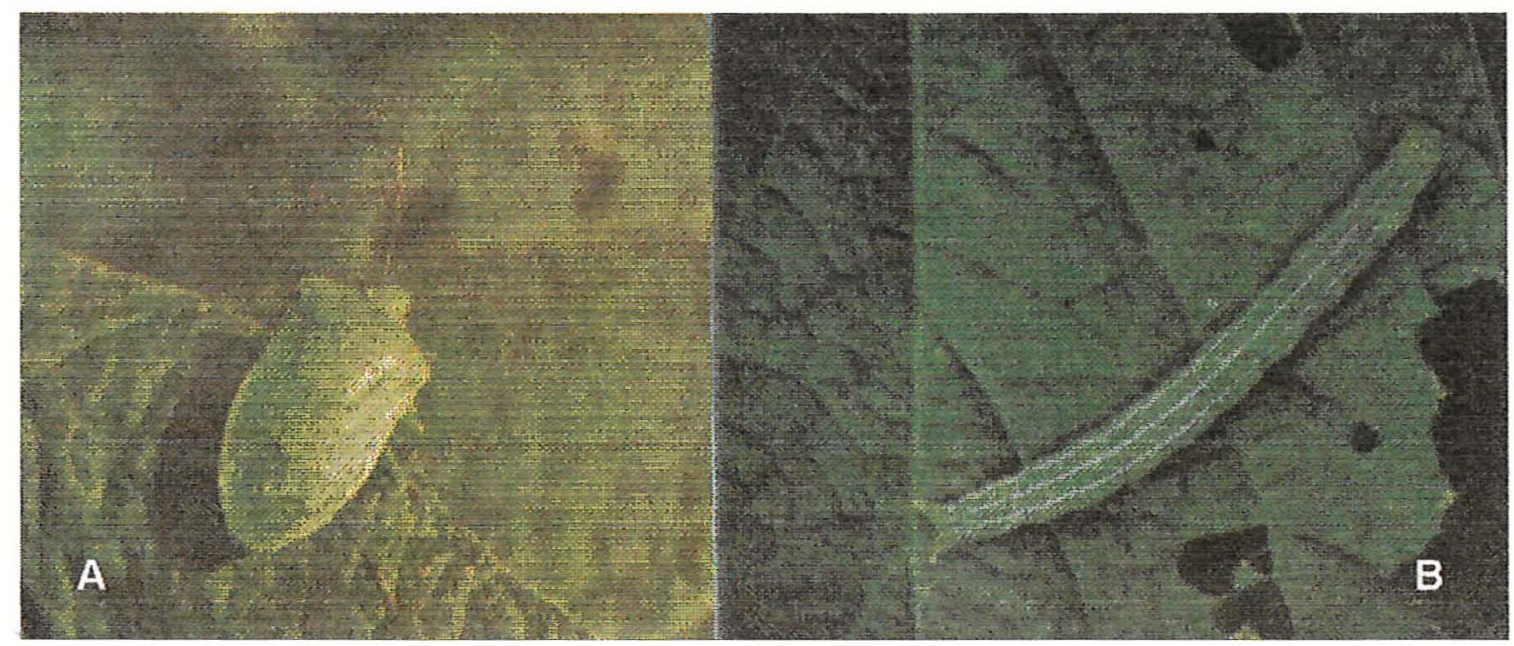

Figura 1: (A) Adulto de Nezara viridula e (B) forma verde de Anticarsia gemmatalis (Gazzoni, 1983).

\subsection{Estresse em plantas}

「Geralmente o termo estresse em plantas gera muitas dúvidas e controvérsias, mas de uma forma geral pode ser definido como: "Uma grande variedade de fatores biológicos e ambientais que cultivares agrícolas e outras plantas estão sujeitas diariamente, como seca, frio, calor, ervas daninhas, insetos e doenças causadas por fungos, vírus e bactérias" (Lichtenthaler, 1996).)

「 De acordo com Prasad, M.N.V. (1997) e Prasad \& Rengel (1998), os fatores estressores podem ser divididos em dois grupos:

1-Fatores Bióticos Antropogênicos: representados pelos compostos aleloquímicos, herbicidas, poliaminas, poluentes do ar, dióxido de carbono $\left(\mathrm{CO}_{2}\right)$, partículas radioativas do solo e fogo; e 
2- Fatores Abióticos Naturais: que compreendem a luz, radiação UV$B$, resfriamento, congelamento, altas temperaturas, seca, alagamento (Andrews, 1996), salinização (Neumann, 1997) e metais pesados, de fundamental interesse e importância ao homem, considerados os principais poluentes do ambiente e com fitotoxicidade bem estabelecida (Ross, 1994), sendo um dos pontos principais neste trabalho.

Além destes, outros fatores estressores merecem destaque, como a deficiência mineral do solo, insetos, ervas daninhas, vírus, fungos e bactérias patogênicas, pesticidas, radiação UV-A, pH do solo e da água, chuva ácida, etc (Lichtenthaler, 1996).

Em geral, as plantas sob condições de estresse exibem um certo padrão de resposta característico à estas situações denominados de Síndrome de Adaptação Geral (GAS), que pode ser dividida em 4 fases distintas: (1) Fase de Resposta, representada pelo início do estresse, caracterizando uma reação de alarme que compreende um declínio da vitalidade; (2) Fase de Restituicão, onde há a permanência do estresse, conferindo um estágio de resistência através de processos de adaptação, reparos e endurecimento; (3) Fase Final, onde um longo período de exposição ao estresse caracteriza um estágio de exaustão, que supera a capacidade de adaptação e induz doenças crônicas ou até mesmo a morte; e (4) Fase de Regeneração, com a regeneração total ou parcial das funções fisiológicas, após a retirada do estresse (Lichtenthaler, 1996 e Leshem et al., 1998) (Fig. 2).

Erdei et al. (1998) sugerem que de acordo com a GAS, o estressor leva a modificações e dessincronização das oscilações dos processos fisiológicos e bioquímicos correspondentes a fase de resposta. A fase de restituição ou aclimatação corresponde a fixação de um novo ritmo circadiano com diferentes processos bioquímicos e fisiológicos, correspondentes às novas condições ambientais, assegurando a máxima resistência do organismo.

Segundo a GAS, os peptídios ligados à metais (MBPs), PCs e mecanismos de bombas transportadoras de íns das membranas são os 
mecanismos de maior importância na desintoxicação das plantas submetidas à altas concentrações de metais pesados (Leshem et al., 1998).

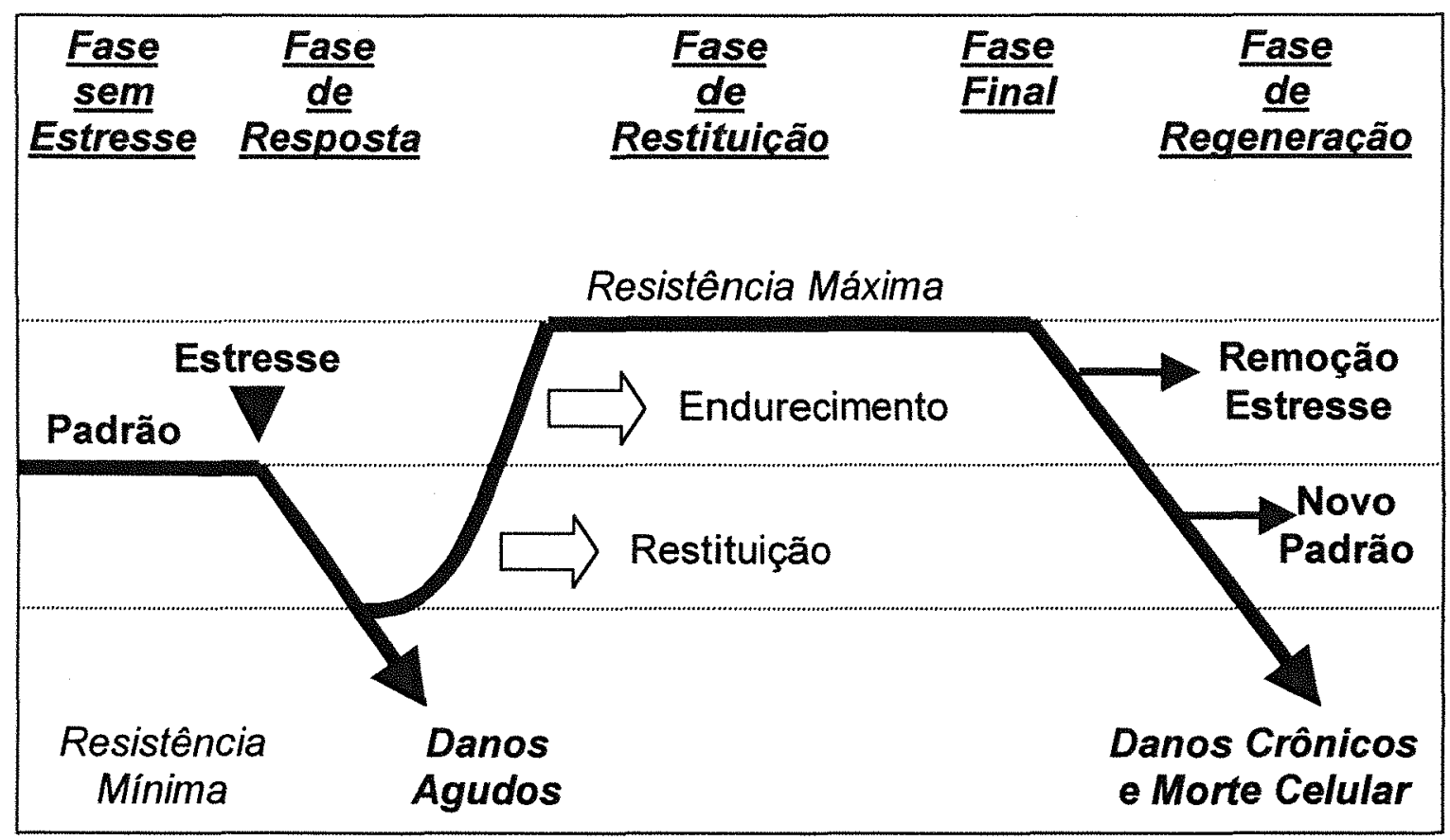

Figura 2: Representação das fases da GAS em plantas sob condições de estresse (Lichtenthaler, 1996 e Leshem et al., 1998).

\subsubsection{Metais pesados poluentes}

O termo "metal pesado" é aplicado a um grupo heterogêneo de elementos, incluindo metais, semimetais e não metais (Melo et al., 1997), que possuem número atômico maior que 20 ou peso específico maior que $5 \mathrm{~g} \mathrm{~cm}^{-3}$ (Malavolta, 1994). Alguns deles são nutrientes essenciais aos vegetais, como o $\mathrm{Cu}, \mathrm{Fe}, \mathrm{Mn}, \mathrm{Ni}, \mathrm{Mo}$ e $\mathrm{Zn}$, outros são benéficos ao crescimento das plantas, como o Co e V, e outros não são essenciais ou não apresentam função, caso do Al, Cd, Cr, Hg e Pb (Melo et al., 1997). 
São também conhecidos por "elementos traços" ou ainda "metais traços", por serem naturalmente encontrados em concentrações de poucas partes por milhão (Mattiazzo-Prezotto, 1994).

Atualmente, os metais pesados têm sido considerados os principais poluentes ambientais e suas bioconcentrações em plantas e ervas daninhas na agricultura, horticultura e silvicultura e em macrófitas aquáticas, são de especial preocupação e interesse ao bem estar humano (Prasad, M.N.V. 1997).

A poluição por metais pesados está aumentando diariamente no ambiente devido à mineração, industrialização e atividades antropogênicas (Ross, 1994) como deposições atmosféricas, agricultura, deposição de desperdícios e aplicações militares. Estes metais causam grande impacto à saúde humana através da cadeia alimentar, por se acumular em carnes, peixes, vegetais, frutas e cereais (Prasad, M.N.V. 1997; Melo et al., 1997 e McGrath et al., 1998).

Metais pesados liberados no ambiente terrestre tendem a se concentrar no solo e sedimentos, que passam a se tornar um grande reservatório disponível para as raízes das plantas, que são muito vulneráveis a variação de concentrações destes elementos. Em ambientes aquáticos estes elementos se disponibilizam tanto para as raízes quanto para a parte aérea (Prasad, M.N.V. 1997). A disponibilidade desses elementos para as plantas é afetada por uma série de fatores, como a textura do solo, tipo de mineral de argila, $\mathrm{pH}$ do solo, $\mathrm{pH}$ da água, potencial redox e outros parâmetros fisiológicos (Prasad, M.N.V. 1997 e Melo et al., 1997).

\subsubsection{A toxicidade do cádmio}

O Cd é um elemento não essencial aos vegetais, conhecido como o mais potencialmente perigoso de todos os metais pesados devido a sua toxicidade aos seres humanos, outros animais (Lee et al., 1976) e plantas (Das et al., 1997), podendo se acumular no corpo humano com uma meia vida 
excedendo 10 anos (Salt et al., 1995). Este metal é prontamente absorvido pelas plantas e translocado para seus órgãos aéreos facilitando sua entrada na cadeia alimentar (Nascimento \& Pereira, 1997 e Malan \& Farrant, 1998). Segundo Wagner (1993), aproximadamente $70 \%$ do $\mathrm{Cd}$ ingerido pelo homem é devido ao consumo de alimentos vegetais.

- Quantidades naturais de Cd no ambiente são geralmente baixas, porém atividades antropogênicas podem aumentar drasticamente estes níveis. Tais atividades incluem a mineração de $\mathrm{Zn}$, fundição, utilização de lodo de esgoto para fertilização na agricultura (Chaoui et al., 1997a), gases liberados pela combustão de combustiveis fósseis, pesticidas (Gimeno-Garcia et al., 1996 e Lagriffoul et al., 1998), aplicação de fertilizantes fosfatados (Chen \& Kao, 1995; Galli et al., 1996 e Iretskaya et al., 1998), fertilizantes com impurezas (Schickler \& Caspi, 1999), processos industriais (Malan \& Farrant, 1998), queimadas e vazamentos (Chen \& Kao, 1995), fabricação de baterias de automóveis, aplicações militares, aeroespaciais, estabilização de plásticos e formulação de pigmentos entre outros (Prasad, 1995).

Em humanos e animais, prolongadas exposições ao $\mathrm{Cd}$ levam à disfunções renais, desmineralização dos ossos (Ghoshroy et al., 1998), enfisemas pulmonares (Salt et al., 1995), destruição de eritrócitos, danos aos testículos, hipersensibilidade à doenças cardíacas (Lee et al., 1976), gastroenterite, câncer, hipertensão (Rossi et al., 1998) e outras doenças, como a itai-itai (Kuboi et al., 1987 e Prasad, 1995), causada por arroz contaminado por Cd na cidade de Toyama no Japão, onde um grande número de vítimas exibiram problemas neurotóxicos e descalcificação óssea acentuada.

O Cd liberado no ambiente tende a se concentrar nos solos e sedimentos (Prasad, M.N.V. 1997), onde formam um reservatório disponivel às plantas, que o absorvem principalmente através das raízes (Chaoui et al., 1997a) e o acumulam em todas as partes incluindo raízes, frutos, grãos (Lagriffoul et al., 1998) e partes aéreas (Jarvis et al., 1976). 
Em recente revisão, Siedlecka \& Krupa (1999), relataram a distribuição de $\mathrm{Cd}$ em diferentes órgãos de plantas superiores, onde $60 \%$ foi encontrado nas raizes, $15 \%$ nas folhas, $15 \%$ nas sementes e $10 \%$ no caule. No que se refere as folhas, $48 \%$ do $\mathrm{Cd}$ foi encontrado na parede celular, $39 \%$ no citoplasma e vacúolo e $13 \%$ nos cloroplastos e mitocôndrias.

Esta habilidade das plantas em compartimentalizar metais pesados nos vacúolos parece representar um papel chave na conferência de tolerância à estes agentes poluentes (McGrath et al., 1998).

Nas raízes, grande parte do $\mathrm{Cd}$ imobilizado parece estar localizado nos Espaços Livres Aparentes (AFS) que representam as soluções dos espaços intercelulares. Quimicamente, o Cd pode se apresentar solúvel em água e complexado nos AFS dos tecidos das raizes e folhas, enquanto que no solo, o $\mathrm{Cd}$ apresenta-se reduzido, extrativo em ácido dietiltriamina pentacético (DTPA) e formas organicamente ligadas (insolúveis) (Prasad, 1995 e Leita et al., 1996).

Muitas espécies podem ser utilizadas para se estudar a fitotoxicidade do $\mathrm{Cd}$ em ambientes com altos niveis deste metal. Em estudos realizados por Mohan \& Hosetti (1997), foram discutidos aspectos fisiológicos e metabólicos utilizando-se uma espécie altamente sensivel ao $\mathrm{Cd}$, a Lemna minor, conhecida como bioindicadora de poluição ambiental por metais. Outras espécies, como algumas plantas terrestres são indicadores de poluição do ar, assim como muitos insetos, peixes, moluscos e algas, são utilizados como indicadores de poluição da água. $\mathrm{O}$ conhecimento dos efeitos tóxicos do $\mathrm{Cd}$ nos processos bioquímicos e fisiológicos são potencialmente necessários para se estabelecer um critério de seleção de plantas que possam ser utilizadas como bioindicadores (Oliveira et al., 1994b).

Outras plantas capazes de acumular metais pesados estão sendo propostas para se utilizar na remoção do excesso de metais dos solos e ambientes aquáticos poluídos, a fim de restaurá-los. Este processo é denominado de fitorremediação e no caso do $\mathrm{Cd}$ é particularmente 
recomendável devido ao seu rápido transporte e acúmulo na parte aérea de várias espécies de plantas (Salt et al., 1995 e McGrath et al., 1998).

Várias espécies de plantas terrestres, mais de 400 em todo o mundo, normalmente endêmicas de solos metaliferos, são conhecidas por sua habilidade de extrair e acumular grandes quantidades de metais em sua parte aérea. Estas plantas podem coletar centenas ou até milhares de vezes mais metais que as plantas normais, sendo assim chamadas de hiperacumuladoras, podendo ser utilizadas tanto na fitorremediação como também na fitomineração. A grande quantidade de $\mathrm{Cd}$ nos tecidos de plantas hiperacumuladoras sugerem a existência de um mecanismo de defesa para evitar os efeitos prejudiciais causados pelo metal (McGrath et al., 1998 e Schickler \& Caspi, 1999).

A absorção, distribuição e efeitos do $\mathrm{Cd}$ nos diferentes processos metabólicos parecem ser controlados por diversos fatores da planta, tais como espécie e/ou variedade, estado nutricional e hídrico, estágio de crescimento e período de exposição ao metal (Oliveira et al., 1994a).

Nas plantas, os sintomas gerais dos processos fisiológicos e metabólicos influenciados pelas concentrações tóxicas de $\mathrm{Cd}$ são: inibição do crescimento radicular e da parte aérea (Boussama et al., 1999a), senescência acelerada nas folhas (Siedlecka \& Krupa, 1999), redução do vigor e interferência no processo de fotossíntese (Prasad, 1995 e Prasad, M.N.V. 1997), devido à alteração nas funções dos estômatos, no transporte de elétrons, no ciclo de Calvin, desordens na estrutura dos grana e na sintese de clorofila (Barceló et al., 1988 e Siedlecka \& Krupa, 1999).

O Cd ainda pode provocar danos à transpiração, translocação através do floema (Rossi et al., 1998), respiração, relações hídricas, reprodução, mudanças em certas organelas, rompimento estrutural e funcional das membranas celulares (Prasad, M.N.V. 1997) e danos às raizes. Também, o aparecimento de uma coloração marrom avermelhada nas margens das folhas, nervuras (Schickler \& Caspi, 1999) e clorose das folhas, tem sido apontada 
como um dos sintomas mais característicos de plantas intoxicadas por este metal (Das et al., 1997), devido ao fato de que o Cd facilmente interage e compete com o Fe (Siedlecka \& Krupa, 1999), Ni (Baccouch et al., 1998) e Cu (Mocquot et al., 1996) por sítios de absorção na membrana plasmática (Nascimento \& Pereira, 1997), suprimindo a absorção desses elementos e induzindo uma deficiência de Fe neste órgão.

Efeitos genéticos e citotóxicos também foram notados em plantas expostas ao metal, onde o $\mathrm{Cd}$ inibiu a divisão celular, promoveu alterações nos cromossomos (aberrações cromossômicas) e induziu picnose nas células das raízes (Das et al., 1997).

Porém, as plantas apresentam diversos mecanismos para responder, combater e superar as adversidades ambientais, tais como a presença do $\mathrm{Cd}$, reduzindo sua fitotoxicidade através da adaptação e resistência genética (Patra \& Panda, 1998), limitação da absorção e desintoxicação. A limitação na absorção consiste em um mecanismo complexo que limita a absorção ou transporte pela interface raiz/parte aérea, como no caso da exudação de substâncias quelantes de metais pelos tecidos das raizes. A desintoxicação é similar a este mecanismo, mas ocorre dentro dos tecidos da planta em compartimentos subcelulares ou em componentes ligados à metais (Leita et al., 1993).

Prasad, M.N.V. (1997), classificou os possiveis mecanismos de tolerância aos metais pesados em plantas como sendo: (1) estruturas de ligação à metais da parede celular, (2) transporte reduzido pelas membranas celulares, (3) afluxo ativo, (4) compartimentalização e (5) quelação e PCs.

\subsection{Fitoquelatinas}

Metais pesados em vertebrados e fungos são desintoxicados por metalotioneínas, as quais são proteínas de $6,5 \mathrm{kD}$ ricas em enxofre. 
Metalotioneínas de mamíferos em geral consiste de um polipeptídio de cadeia simples com 61 residuos de aminoácidos (Grill et al., 1985).

Em plantas tolerantes, a acumulação e acomodação do $\mathrm{Cd}$ são responsabilidade de vários mecanismos, tais como a associação à sítios de troca de cátions nas paredes celulares, seqüestro no vacúolo por ácidos orgânicos, sendo muito freqüentes metais quelados no interior dos vacúolos (Vögeli-Lange \& Wagner, 1996), indicando um transporte através do citoplasma (Leopold et al., 1999) e complexação com glutationa (GSH) e outras moléculas no citosol.

Em muitos casos a desintoxicação de metais pesados, especialmente Cd, está ligada a síntese de polipeptídios de baixa massa molecular, formados de unidades repetidas de $\gamma$-glutamil-cisteina seguido por uma glicina na porção C-terminal (Howden et al., 1995) que são caracterizados pelo grande conteúdo de cisteínas e alta afinidade à metais pesados e denominados de PCs (Grill et al., 1985; Leita et al., 1991; Vögeli-Lange \& Wagner, 1996; Tukendorf et al., 1997 e Prasad, M.N.V. 1997), proteinas ligadas a metais (MBPs), metalotioneínas classe III ou ainda, cadistinas (Reese et al., 1992).

As PCs são também conhecidas como poli ( $\gamma$-glutamil-cisteinil) glicinas (Hagen et al., 1988) com estrutura molecular geral ( $\gamma$-ácido glutâmicocisteina) ${ }_{n}$-glicina com $n=2-11$ (Grill et al., 1985). Em algumas plantas superiores, estes polipeptídios se apresentam com uma estrutura molecular um pouco diferenciada, sendo denominadas de homofitoquelatinas (Tukendorf et al., 1997 e Przymusinski \& Gwózdz, 1999).

Em tabaco, por exemplo, plântulas crescidas na presença $\mathrm{Cd}$ apresentaram todo o Cd e PCs localizados no interior dos vacúolos das células das folhas (Vögeli-Lange \& Wagner, 1990).

Estudos indicam que as PCs são derivadas da GSH ( $\gamma$-glutamilcisteinil-glicina), que é considerada o componente tiol (SH) predominante nas células vegetais (Tukendorf et al., 1997 e Lee \& Leustek, 1999). Isto se 
evidencia, devido ao fato da síntese de PCs estar acompanhada pela diminuição do estoque de GSH nas raizes e culturas de células. Outra evidência vem do tratamento de culturas de células vegetais com butionina sulfoximina (BSO), um inibidor da enzima $\gamma$-glutamil-cisteina sintetase $(\gamma$-EC) da via de biossintese de GSH, onde a BSO inibe também a sintese de PCs.

A sintese de PCs é realizada por uma enzima denominada fitoquelatina sintase, dependente de gutamato e cisteína, que catalisa a transpeptidação da $\gamma$-EC de uma GSH para outra, ou para constituir a cadeia polipeptídica das PCs (Jemal et al., 1998 e Boussama et al., 1999b).

Ju et al. (1997), relataram que a adição de Cd induziu um incremento na atividade de $\gamma$-EC nas raizes e folhas de milho, juntamente com a síntese de PCs.

Além da síntese de PCs estar envolvida com GSH, o enxofre parece incorporar facilmente nas cadeias de PCs e aumentar a afinidade destes ao $\mathrm{Cd}$, reduzindo a quantidade de sulfatos nas plantas (Reese et al., 1992).

A diminuição do conteúdo de GSH na presença de metais pesados, tais como o $\mathrm{Cu}$ e $\circ \mathrm{Cd}$, resulta em um aumento no estresse oxidativo, ligado com a peroxidação lipídica das membranas celulares, um dos sintomas comuns deste estresse (Lozano-Rodriguez et al., 1997), que representa um dos principais efeitos tóxicos dos metais pesados aos seres vivos (Lagriffoul et al., 1998).

\subsection{Estresse oxidativo}

$\mathrm{O}$ acúmulo de oxigênio molecular $\left(\mathrm{O}_{2}\right)$ na atmosfera da terra permitiu a evolução dos organismos aeróbicos que utilizam $\circ \mathrm{O}_{2}$ como aceptor final de elétrons, fornecendo uma alta produção de energia comparada com a fermentação e respiração anaeróbica (Scandalios, 1993). 
Em seu estado fundamental, $\circ \mathrm{O}_{2}$ é uma molécula relativamente não reativa, mas é capaz de dar origem a estados excitados reativos letais, como radicais livres e derivados. Radical livre é uma molécula ou íon que contém um elétron não pareado (Rice-Evans et al., 1991).

Os radicais livres, entre eles o superóxido $\left(\mathrm{O}_{2}^{-}\right)$e hidroxila $\left(\mathrm{OH}^{\circ}\right)$, são produzidos sob condições ótimas (Foyer et al., 1994) e são essenciais para muitos processos biológicos, sendo intermediários e/ou produtos de várias reações catalisadas por enzimas, principalmente à respiração e fotossíntese (Scandalios, 1993). Cakmak \& Marschner (1992) estimaram que sob condições normais, em cloroplastos não estressados, a fotorredução do oxigênio molecular varia entre 5 a $27 \%$ do fluxo total de elétrons.

Porém, radicais livres podem se tornar altamente destrutivos para células e tecidos se sua produção não for firmemente controlada (Rice-Evans et al., 1991).

Alguns dos importantes oxidantes de sistemas biológicos não são radicais, por exemplo, peróxido de hidrogênio $\left(\mathrm{H}_{2} \mathrm{O}_{2}\right)$ e o oxigênio "singlet" $\left({ }^{1} \mathrm{O}_{2}\right)$ (Bentivenga et al., 1999), no entanto eles são capazes de produzir danos oxidativos em materiais biológicos, sendo denominados genericamente, tanto os radicais livres como estas espécies, de espécies reativas de oxigênio (ROS) (Rice-Evans et al., 1991).

Lagriffoul et al. (1998), definiram estresse oxidativo como todos os efeitos causados pelas ROS. De acordo com Guyton (1992), os radicais livres de oxigênio literalmente afogam os sistemas enzimáticos que o removem, tendo então, efeitos destrutivos graves e até mesmo letais sobre as células. Um dos principais efeitos é o de oxidar os ácidos graxos polinsaturados, processo mais conhecido como peroxidação lipídica (Bhattacharjee, 1997 e 1998), que são componentes essenciais de muitas das estruturas membranosas das células, afetando sua integridade funcional e estrutural (Chaoui et al., 1997b). O outro efeito é a oxidação de algumas enzimas celulares, danificando gravemente os sistemas metabólicos celulares. 
Em plantas, as ROS são produzidas em reações ocorridas nas mitocôndrias, cloroplastos e peroxissomos (Azevedo et al., 1998), preferencialmente associados à eventos dependentes de luz. Células fotossintetizantes estão sempre propensas ao estresse oxidativo devido ao fato destas conterem pigmentos que produzem e consomem oxigênio (Foyer et al., 1994). Sabe-se que durante o período de luz, o cloroplasto se torna rapidamente o compartimento mais aeróbico da natureza (Barata, 1999).

Segundo Foyer et al. (1994), os principais processos consumidores de oxigênio molecular associados à fotossíntese são (a) a reação oxigenase da rubisco, a qual é iniciadora da via fotorrespiratória e (b) redução direta do $\mathrm{O}_{2}$ pela cadeia transportadora de elétrons do fotossistema I (PSI) e certos componentes do fotossistema II (PSII). Portanto, o aparato fotossintético isto é, o complexo coletor de luz associado com PSII, o centro de reação do PSIl e o lado aceptor do PSI, são os três principais sítios geradores de ROS do cloroplasto (Niyogi, 1999).

Asada (1999), sugere que na oxigenação fototrófica, cloroplastos têm sido identificados como sítios geradores de $\mathrm{O}_{2}$ à partir da oxidação da água $\left(\mathrm{H}_{2} \mathrm{O}\right)$, produzindo $\mathrm{O}_{2}{ }^{\circ}$ - intermediários que são convertidos à $\mathrm{H}_{2} \mathrm{O}_{2}$. Estes $\mathrm{H}_{2} \mathrm{O}_{2}$ não se acumulam, indicando a existência de um sistema redutor de $\mathrm{O}_{2}$ à $\mathrm{H}_{2} \mathrm{O}$ que utilizam elétrons derivados da própria $\mathrm{H}_{2} \mathrm{O}$, sendo denominado de ciclo água-água (Fig. 3).

As cadeias transportadoras de elétrons dos cloroplastos e das mitocôndrias são duas importantes fontes de ROS, onde $\mathrm{O}_{2} \mathrm{O}_{2}^{-}$tem sido demonstrado ser gerado também até nos peroxissomos (Jiménez et al.,1997).

Foyer et al. (1994) afirma que, in vivo, a maioria dos $\mathrm{O}_{2}^{\circ}-$ são formados via ferredoxina $(F d)$ reduzida, através da reação:

$$
2 \mathrm{O}_{2}+2 \mathrm{Fd}_{\text {red }} \rightarrow 2 \mathrm{O}_{2}^{\circ}+2 \mathrm{Fd}_{\mathrm{ox}}
$$




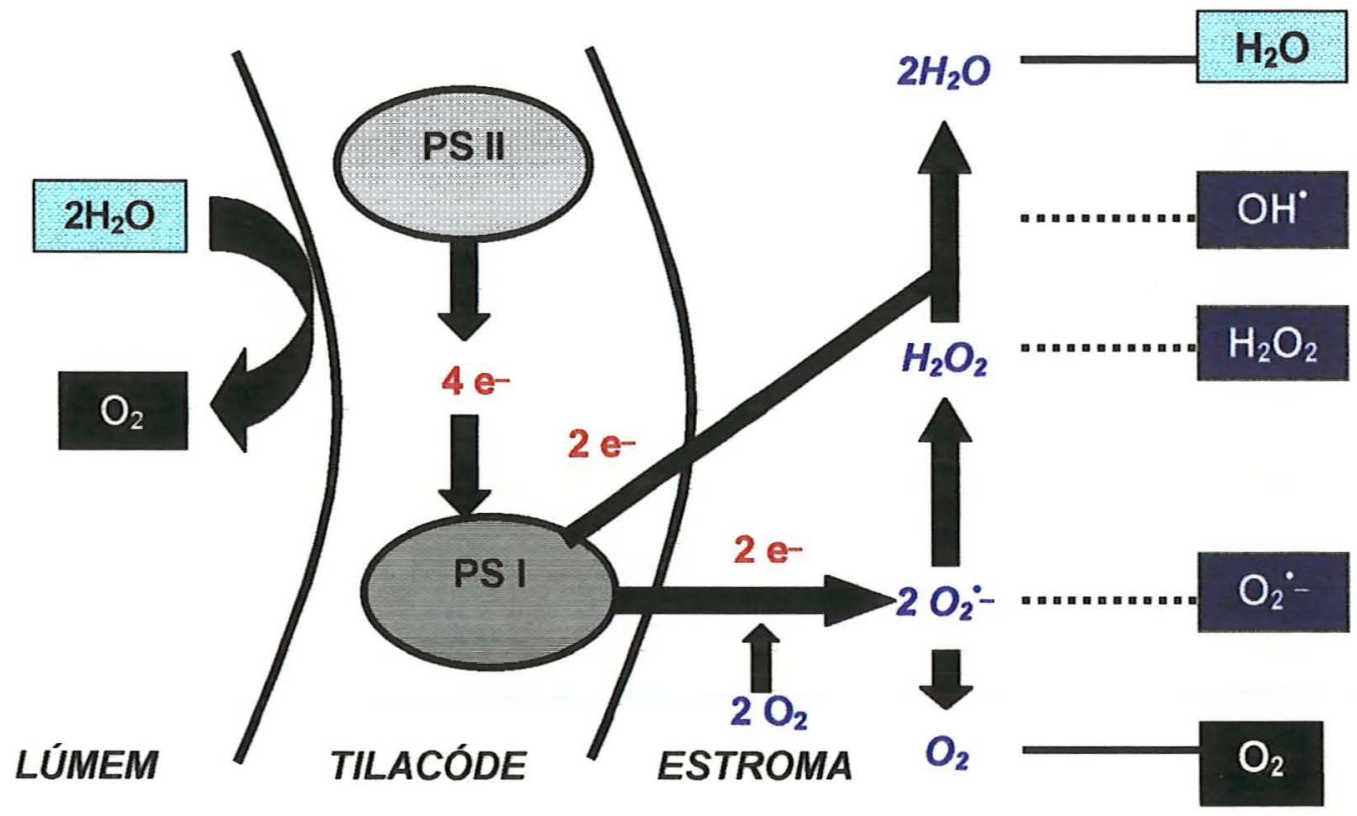

Figura 3: Esquema do ciclo água-água nos cloroplastos e a formação de ROS intermediários. No PSI duas moléculas de $\mathrm{O}_{2}$ são reduzidas à $\mathrm{O}_{2}^{\circ}-$, que é convertido à $\mathrm{H}_{2} \mathrm{O}_{2}$ e $\mathrm{O}_{2}$. $\mathrm{O} \mathrm{H}_{2} \mathrm{O}_{2}$, por sua vez é reduzido à $\mathrm{H}_{2} \mathrm{O}$. Neste processo uma molécula de $\mathrm{O}_{2}$ é reduzida a duas moléculas de $\mathrm{H}_{2} \mathrm{O}$ (Asada, 1999).

Os $\mathrm{O}_{2}{ }^{\circ}$ - e os $\mathrm{H}_{2} \mathrm{O}_{2}$ podem reagir entre si e formar $\mathrm{OH}^{\circ}$, através de uma reação catalisada por metais ( $\mathrm{Fe}$ ou $\mathrm{Cu}$ ) denominada reação de Haber-Weiss (Becana et al., 1998 e Mattson, 1998):

$$
\begin{gathered}
\mathrm{O}_{2}^{\circ-}+\mathrm{Fe}^{3+} \Rightarrow \mathrm{O}_{2}+\mathrm{Fe}^{2+} \\
\mathrm{Fe}^{2+}+\mathrm{H}_{2} \mathrm{O}_{2} \Rightarrow \mathrm{Fe}^{3+}+\mathrm{OH}^{\circ}+\mathrm{OH}^{\circ} \\
\mathrm{O}_{2}^{\circ-}+\mathrm{H}_{2} \mathrm{O}_{2} \Rightarrow \mathrm{O}_{2}+\mathrm{OH}^{\circ}+\mathrm{OH}^{\circ}
\end{gathered}
$$

Os $\mathrm{OH}^{\circ}$, considerados os mais potentes oxidantes conhecidos (Scandalios1993), podem atacar rapidamente todos os tipos de biomoléculas, podendo causar danos em diversos componentes celulares, lesões no DNA e 
mutações entre outras coisas, levando a disfunções metabólicas irreparáveis e morte celular (Jiménez et al., 1997) (Fig. 4).

\section{Efeitos \\ Moleculares \\ Efeitos Celulares}

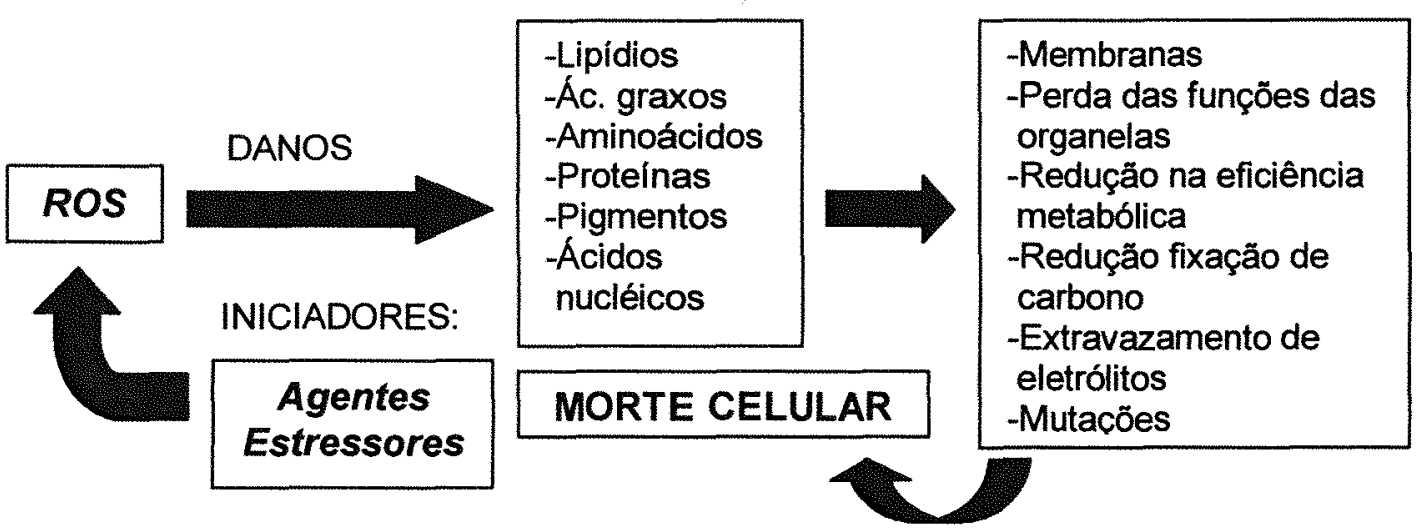

Figura 4: Esquema mostrando iniciadores de $\mathrm{ROS} e$ as conseqüências biológicas levando à disfunções biológicas e morte celular (Scandalios, 1993).

Assim, podemos afirmar que a função do oxigênio é paradoxal. Por um lado, em sua forma molecular oxidada $\left(\mathrm{O}_{2}\right)$, é essencial para a vida aeróbica, por outro, em sua forma reduzida é uma das substâncias mais tóxicas para os seres vivos (Ruiz, 1998). Fica evidente que um dos maiores problemas sofridos pelos organismos aeróbicos, até então, é a necessidade de efetivamente eliminar as ROS, tanto as geradas durante as atividades metabólicas normais como aquelas induzidas por agentes estressores. As plantas em particular, através de pressão de seleção ao longo do processo evolutivo, desenvolveram numerosos mecanismos de defesa enzimáticos e não enzimáticos eficazes para proteção de suas células contra os danos oxidativos provocados pelas ROS (Bowler et al., 1992; Scandalios, 1993 e Prasad \& Rengel, 1998).

Entre os mecanismos não enzimáticos, estão compostos de baixa massa molecular, como GSH, AsA (Prasad \& Rengel, 1998 e Asada, 1999), 
flavonóides e pigmentos carotenóides (Foyer et al., 1994), que agem em conjunto com os mecanismos enzimáticos, representados genericamente pelas enzimas antioxidantes (Scandalios, 1993).

\subsection{Enzimas antioxidantes}

O sistema de defesa enzimático antioxidante é formado por enzimas capazes de remover, neutralizar ou limpar as ROS do interior das células de organismos vivos (Scandalios, 1993).

Dentre as principais enzimas antioxidantes, podemos destacar a SOD, CAT e GR de interesse particular neste trabalho, e outras como APX, POX e MDAR (Prasad \& Rengel, 1998 e Aono et al., 1998).

A ação combinada do sistema não enzimático auxiliando no processo de desintoxicação celular e enzimático, convertendo os produtos potencialmente perigosos aos sistemas biológicos das ROS, é importante em evitar os danos oxidativos celulares tão prejudiciais aos organismos vivos submetidos à variadas condições de estresses (Scandalios, 1993).

\subsubsection{Superóxido dismutase}

A enzima SOD (Superóxido:superóxido oxidorredutase, E.C.1.15.1.1.) catalisa a dismutação do $\mathrm{O}_{2} \cdot-$ à $\mathrm{H}_{2} \mathrm{O}_{2}$, apresentando-se na forma de isoenzimas (Giannopolitis \& Ries, 1977; Vallejos, 1983; Bowler et al., 1992 e Voet \& Voet, 1995).

De acordo com Mattson (1998) a dismutação consiste em uma reação na qual dois substratos idênticos se transformam em dois produtos diferentes. Neste caso, cada duas moléculas de $\mathrm{O}_{2}{ }^{\circ}$ - consumidas, uma molécula de $\mathrm{O}_{2}$ e uma de $\mathrm{H}_{2} \mathrm{O}_{2}$ são geradas. Para a reação química acontecer, o íon metálico do sítio ativo da enzima deve variar entre seu estado oxidado e reduzido, estando $\mathrm{O}_{2}{ }^{\circ}$ - envolvido em ambas reações: 
Reação Geral:

$$
\mathrm{O}_{2}^{-}+\mathrm{O}_{2}^{-}+2 \mathrm{H}^{+} \rightarrow \mathrm{O}_{2}+\mathrm{H}_{2} \mathrm{O}_{2}
$$

Cu/Zn-SOD:

$$
\begin{aligned}
& \mathrm{Cu}^{2+}+\mathrm{O}_{2}^{-} \rightarrow \mathrm{Cu}^{+}+\mathrm{O}_{2} \\
& \mathrm{Cu}^{+}+\mathrm{O}_{2}^{-} \rightarrow \mathrm{Cu}^{2+}+\mathrm{H}_{2} \mathrm{O}_{2}
\end{aligned}
$$

As isoenzimas da SOD são ubiquas em organismos aeróbicos, anaeróbicos aerotolerantes e alguns anaeróbicos obrigatórios, protegendo-os contra os danos oxidativos através da remoção do radical $\mathrm{O}_{2}{ }^{-}$- Estas enzimas são codificadas no núcleo e transportadas para seus locais organelares por meio de seqüências marcadas com $\mathrm{NH}_{2}$ terminais.

São as únicas enzimas em que suas atividades determinam as concentrações de $\mathrm{O}_{2}^{\circ}-$ e $\mathrm{H}_{2} \mathrm{O}_{2}$, os dois substratos da reação de Haber-Weiss que origina os radicais $\mathrm{OH}^{\circ}$ e provavelmente por isso, as SODs representam o mecanismo de defesa central dos organismos vivos (Bowler et al., 1992 e Alscher et al., 1998).

Estas metaloenzimas multiméricas têm sido classificadas em três grupos de acordo com o componente metálico de seu sítio ativo: cobre/zinco (Cu/Zn), manganês (Mn) ou ferro (Fe) (Pan \& Yau, 1991; Bowler et al., 1992; Scandalios, 1993; Mattson, 1998 e Niyogi, 1999). O número de isoenzimas de cada tipo de SOD varia grandemente de planta para planta (Bowler et al., 1992), sendo que a Cu/Zn-SODs são consideradas as mais abundantes em vegetais (Wingsle et al., 1991). As Cu/Zn-SODs e algumas Mn-SODs e FeSODs de procariotos são diméricas, enquanto as Mn-SODs das mitocôndrias e de algumas bactérias termófilas são tetraméricas (Newton, 1983 e Scandalios, 1993).

De maneira geral, as Cu/Zn-SODs são encontradas no citosol e no estroma dos cloroplastos ou ligadas à membrana dos tilacóides de células eucarióticas, sendo observada também nos espaços intratilacóides (lúmem) (Hayakawa et al., 1984) e são sensiveis à concentrações milimolares de KCN (cianeto de potássio) e $\mathrm{H}_{2} \mathrm{O}_{2}$. As $\mathrm{Mn}$-SODs apresentam insensibilidade ao $\mathrm{KCN}$ 
e $\mathrm{H}_{2} \mathrm{O}_{2}$ e tem sido encontradas geralmente na matriz mitocondrial de células eucarióticas e em células procarióticas, embora uma Mn-SOD associada a membrana foi observada nos cloroplastos de algumas plantas (Sehmer \& Dizengremel, 1998). As Fe-SODs são geralmente encontradas em procariotos e em algumas plantas, presentes no estroma dos cloroplastos, peroxissomos e mitocôndrias de tecidos não fotossintetizantes (Becana et al., 1998), sendo insensiveis ao $\mathrm{KCN}$ e irreversivelmente inativadas pelo $\mathrm{H}_{2} \mathrm{O}_{2}$ (Newton, 1983; Wingsle et al., 1991; Pan \& Yau, 1991; Bowler et al., 1992; Scandalios, 1993 e Azevedo et al., 1998).

Bowler et al. (1992) relataram em seus estudos de filogenia da SOD que a Mn-SOD e Fe-SOD são as mais antigas, indicando que provavelmente evoluíram antes da divergência entre procariotos e eucariotos, enquanto que a $\mathrm{Cu} / \mathrm{Zn}-\mathrm{SOD}$, mais recente, evoluiu independentemente em algum ponto no início da linhagem eucariótica, indicando uma dupla evolução desta enzima.

A SOD por apresentar um importante papel no mecanismo de defesa das plantas, tem sido utilizada em pesquisas envolvendo a manipulação genética, na tentativa de obtenção de fenótipos tolerantes à estresses. Isto foi testado em plantas transformadas de tabaco e tomate, que receberam um gene derivado de cloroplastos de petúnia que codificava a enzima Cu/Zn-SOD. Após indução do estresse, esperava-se uma superexpressão dessa isoforma de SOD, mas nenhuma diferença foi encontrada em relação às plantas normais, concluindo-se que somente o aumento da atividade de SOD não foi suficiente para conferir proteção contra a toxicidade das ROS devido ao aumento da produção de $\mathrm{H}_{2} \mathrm{O}_{2}$, sugerindo um mecanismo integrado de defesa formado por componentes antioxidantes enzimáticos e não enzimáticos (Bowler et al., 1992). 


\subsubsection{Catalase}

As isoenzimas da CAT $\left(\mathrm{H}_{2} \mathrm{O}_{2}: \mathrm{H}_{2} \mathrm{O}_{2}\right.$ oxidorredutase, EC.1.11.1.6.) (Vallejos, 1983), representam um dos mais importantes catalisadores conhecidos, sendo as reações que elas catalisam cruciais para a vida. As CATs utilizam $\circ \mathrm{H}_{2} \mathrm{O}_{2}$ para oxidação de toxinas incluindo compostos fenólicos, ácido fórmico, formaldeído e álcoois (Rice-Evans et al., 1991) e principalmente catalisam a conversão de $\mathrm{H}_{2} \mathrm{O}_{2}$ em $\mathrm{O}_{2}$ e $\mathrm{H}_{2} \mathrm{O}$ (Voet \& Voet, 1995), conforme a seguinte reação:

\section{CAT}

\section{$2 \mathrm{H}_{2} \mathrm{O}_{2}$}

\section{$2 \mathrm{H}_{2} \mathrm{O}+\mathrm{O}_{2}$}

As CATs são proteínas tetraméricas que contém quatro grupos heme encontradas em uma variedade de organismos, de bactérias aeróbicas à plantas e animais superiores, com massa molecular variando entre 220 à 270 kDa (Kato et al., 1997). Em plantas superiores, as CATs representam um importante papel no mecanismo de defesa antioxidante e de transduções de sinais, que responde à estresses ambientais, bem como à estresses oxidativos fisiológicos induzidos pelo $\mathrm{H}_{2} \mathrm{O}_{2}$. As CATs concentram-se no citoplasma, principalmente nos peroxissomos de folhas e glioxissomos de tecidos que armazenam lipídios, com exceção da CAT-3 de milho e da CAT de algumas algas verdes que são mitocondriais, embora esta última com papel fisiológico obscuro (Skadsen et al., 1995; Frugoli et al., 1996 e Iwamoto et al., 1998).

As CATs removem principalmente os $\mathrm{H}_{2} \mathrm{O}_{2}$ gerados nos peroxissomos foliares, pela oxidação do glicolato na fotorrespiração em plantas C3 (Fig. 5). Estas enzimas atuam também nos glioxissomos e nas mitocôndrias, combatendo os $\mathrm{H}_{2} \mathrm{O}_{2}$ produzidos na $\beta$-oxidação dos ácidos graxos e na cadeia transportadora de elétrons (Holtman et al., 1993; Frugoli et al., 1996; Kato et al., 1997 e Pimentel, 1998). 


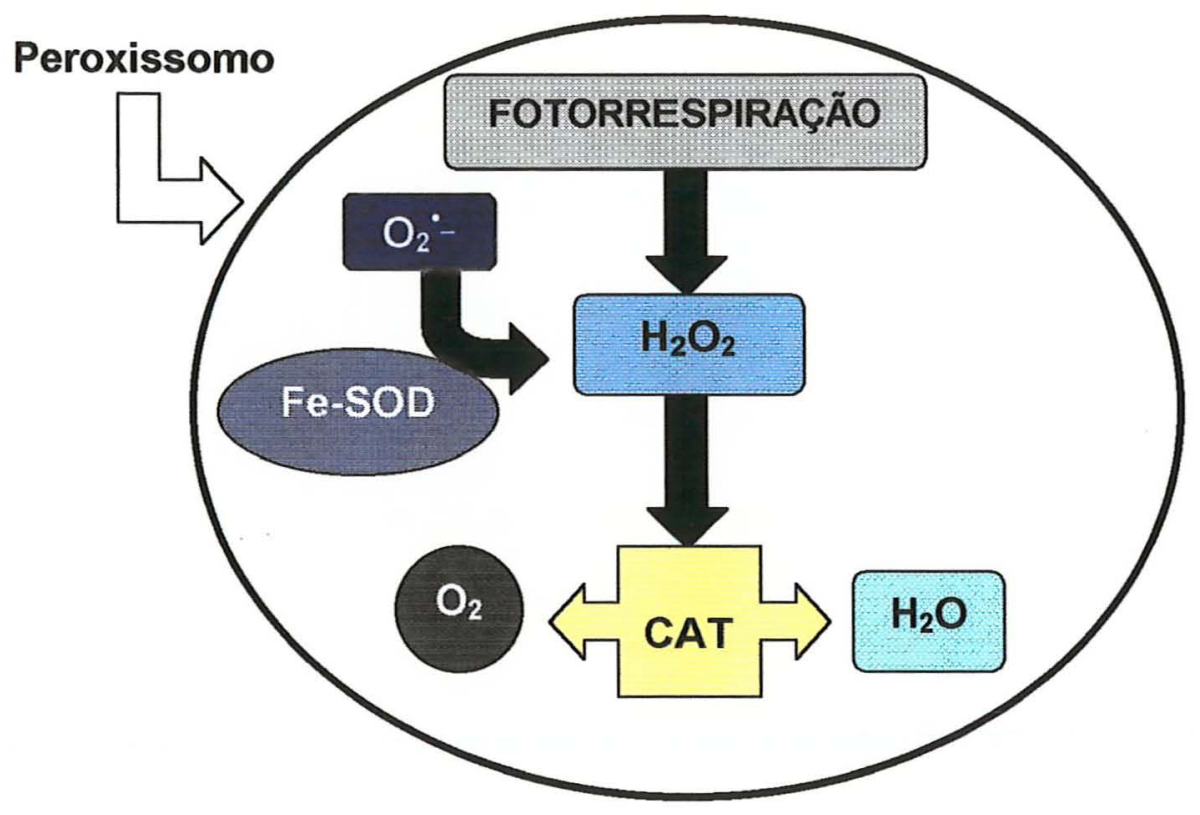

Figura 5: Esquema da atuação da CAT na conversão do $\mathrm{H}_{2} \mathrm{O}_{2}$, produzido pelos processos fotorrespiratórios em plantas $\mathrm{C} 3$ e dismutação dos radicais $\mathrm{O}_{2}{ }^{\circ}$ - pela Fe-SOD em $\mathrm{H}_{2} \mathrm{O}$ e $\mathrm{O}_{2}$.

Diferentes isoformas de CAT têm sido observadas e muitos genes que codificam estas isoenzimas têm sido clonados e caracterizados em bactérias, leveduras, plantas dicotiledôneas (Arabidopsis, algodão, ervilha, girassol, tabaco e tomate) e monocotiledôneas (milho e arroz) (Skadsen et al., 1995).

A grande diversidade molecular da catalase pode ser exemplificada pelas isoformas de plantas de milho, que são codificadas por três genes Cat-1, Cat-2 e Cat-3, localizados nos cromossomos 5S, $1 \mathrm{~S}$ e $1 \mathrm{~L}$, respectivamente (McMillin, 1983 e Havir \& McHale, 1989). Estes genes são responsáveis pela codificação das isoenzimas CAT-1, CAT-2 e CAT-3 que são expressas diferencialmente dependendo do tecido e estágio de desenvolvimento da planta, indicando o envolvimento de mecanismos de controle póstranscricionais (Auh \& Scandalios, 1997). 
Polidoros \& Scandalios (1998) relataram a resposta dos genes da CAT do milho no desenvolvimento das folhas em relação à luz. A expressão do gene Cat-1 não foi dependente de luz, enquanto que o gene Cat-2 foi positivamente regulado pela luz e a expressão do gene Cat-3, apresentou-se regulada por um ritmo circadiano. A acumulação máxima de mRNA do gene Cat-3 aconteceu no período claro e acumulação mínima no escuro, indicando uma alta demanda da isoenzima da CAT-3 para o metabolismo da planta no período inicial de escuro, sugerindo que a CAT-3 é necessária ao processo devido a excessiva formação de $\mathrm{H}_{2} \mathrm{O}_{2}$ durante este período de escuro, atribuída principalmente à diminuição da atividade de APX ou às flutuações diurnas na produção de ROS nas mitocôndrias.

Evolutivamente, assume-se que o gene primordial da catalase em angiospermas, utilizando-se Arabidopsis thaliana como representante, possuía 7 introns e localizava-se no cromossomo 1. Este gene ancestral sofreu uma duplicação em tandem e produziu os genes progenitores Cat-3 e Cat-1, sendo que o gene da Cat-1, após sofrer segunda duplicação se inseriu no cromossomo 4, originando o gene progenitor Cat-2. Seguindo este processo, certamente houve perda de íntrons dos genes Cat-1 e Cat-3, formando possivelmente três isoenzimas diferentes (Iwamoto et al., 1998 e Frugoli et al., 1998).

\subsubsection{Glutationa redutase}

A GSH ( $\gamma$-glutamil-cisteinil-glicina) é considerada essencial às células de plantas e animais, estando envolvida em inúmeros processos celulares, sendo utilizada na armazenagem e transporte de formas reduzidas de enxofre, tendo importante papel na defesa das plantas contra uma variedade de estresses oxidativos, incluindo poluição do ar, calor, frio, seca, e outros fatores estressores (Lea et al., 1998). A GSH está também envolvida no metabolismo 
de xenobióticos, incluindo herbicidas, pela ação da enzima glutationa-Stransferase (GST) e na síntese de PCs para desintoxicação de ions metálicos (Lea et al., 1998) (Fig. 6).

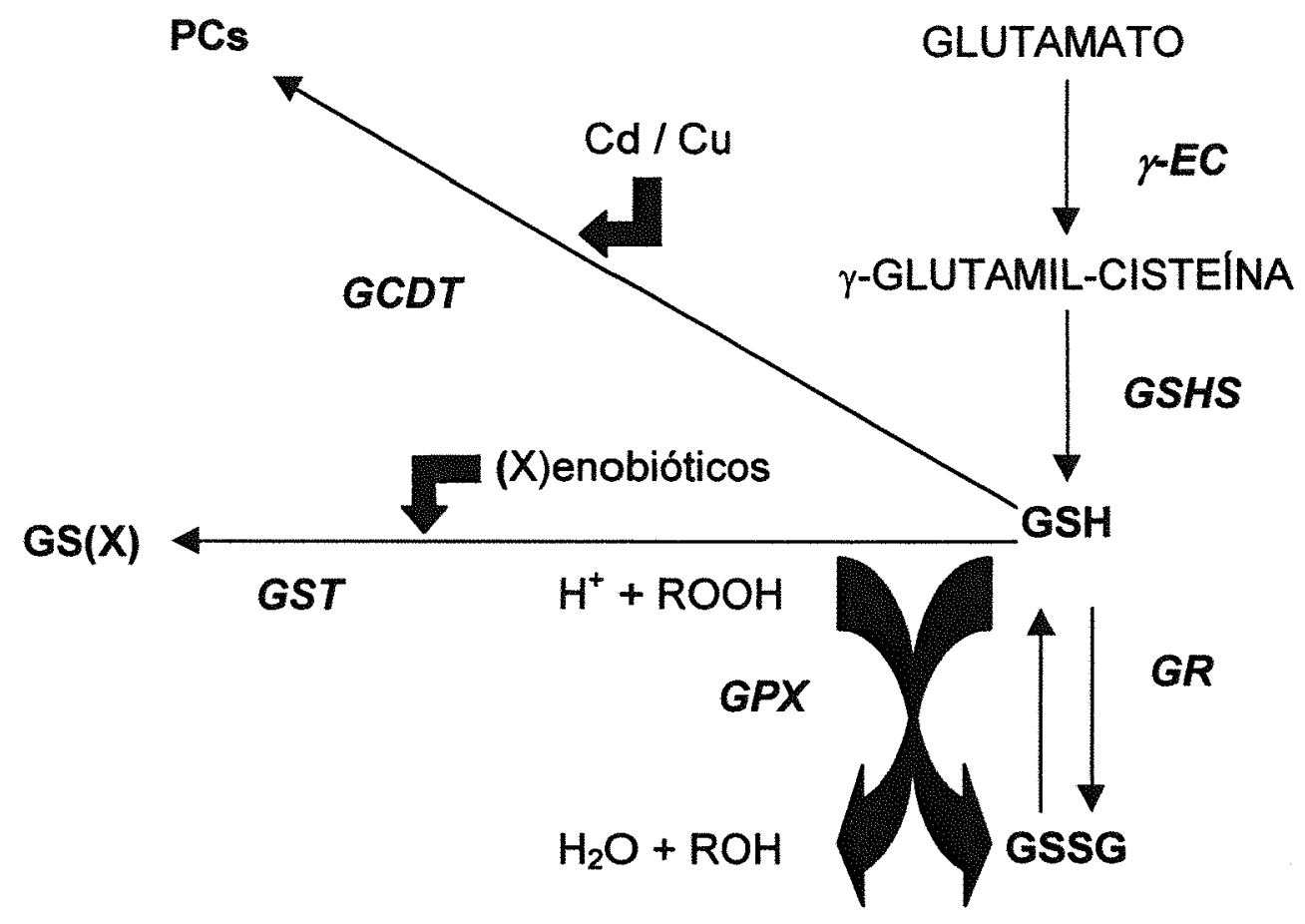

Figura 6: Representação da síntese de GSH, sua redução pela GR e sua utilização pela GPX para recuperar as $\mathrm{ROOH}$ ou, se $\mathrm{R}=\mathrm{H}$ para remover $\mathrm{H}_{2} \mathrm{O}_{2}$, ou pela GST para desintoxicar xenobióticos ou para a sintese de PCs durante a remoção de íons de metais pesados. As enzimas $\gamma$-EC, GSHS e CGDT também participam neste processo (Lea et al., 1998).

A concentração de GSH varia entre as espécies, em diferentes órgãos da mesma planta e até entre os diferentes compartimentos celulares, sendo muito alta nos cloroplastos, por participar da reciclagem do AsA por meio das atividades das enzimas do ciclo Halliwell-Asada (via glutationa-ascorbato).

Particularmente, em plantas de ervilhas, um nivel baixo de atividade de GR foi detectado nas mitocôndrias foliares (Creissen et al., 1994 e Lea et 
al., 1998). A presença do ciclo Halliwell-Asada nos peroxissomos das folhas de ervilha também foi observado, sugerindo um mecanismo de defesa endógeno contra os $\mathrm{H}_{2} \mathrm{O}_{2}$ e $\mathrm{O}_{2}{ }^{-}$- superproduzidos dentro destas organelas, ou mesmo um papel no processo de transdução de sinais que leva a uma expressão gênica especifica regulando a concentração citosólica de moléculas sinalizadoras de $\mathrm{H}_{2} \mathrm{O}_{2}$ (Jiménez et al., 1997).

A GSH como visto, é um importante metabólito no combate as ROS $\left(\mathrm{O}_{2}{ }^{\circ}-e \mathrm{H}_{2} \mathrm{O}_{2}\right)$ via ciclo Halliwell-Asada, onde a enzima chave é a GR (Lea et al., 1998).

A enzima GR (NADPH : glutationa oxidada oxidorredutase, E.C.1.6.4.2.) (Vallejos, 1983) é uma enzima quase ubiqua, amplamente distribuída em procariotos e eucariotos, desde bactérias heterotróficas e fotossintetizantes até plantas e animais superiores (Creissen et al., 1994). A GR contém um grupo prostético flavina adenina dinucleotídeo (FAD) transferidor de elétrons que catalisa a redução dependente de NADPH da glutationa oxidada (GSSG) para glutationa reduzida (GSH) (Creissen et al., 1994 e Voet \& Voet, 1995), conforme a seguinte reação:

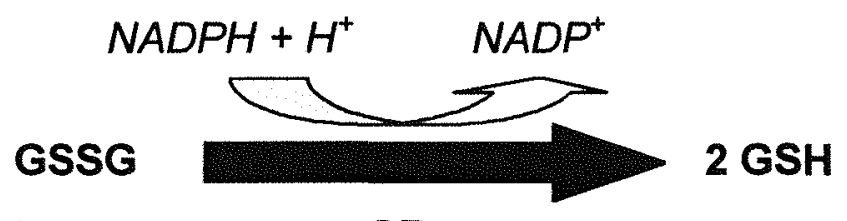

GR

Em resposta à exposição a estresses ambientais tem sido relatado aumento na atividade de GR em algumas espécies de plantas (Lea et al., 1998), sendo encontradas isoformas nos cloroplastos, citosol e mitocôndrias (Donahue et al., 1997).

Foyer et al. (1994) concluíram que as enzimas do ciclo HalliwellAsada estão envolvidas na destruição das ROS, geradas durante o ciclo águaágua (Asada, 1999), onde são primariamente combatidos a nível de tilacóides, 
pelas SODs e APXs ligadas ao tilacóide. Já as SODs e APXs do estroma representam um segundo nível de defesa contra as ROS que chegam a escapar das formas ligadas à membrana (Fig. 7).

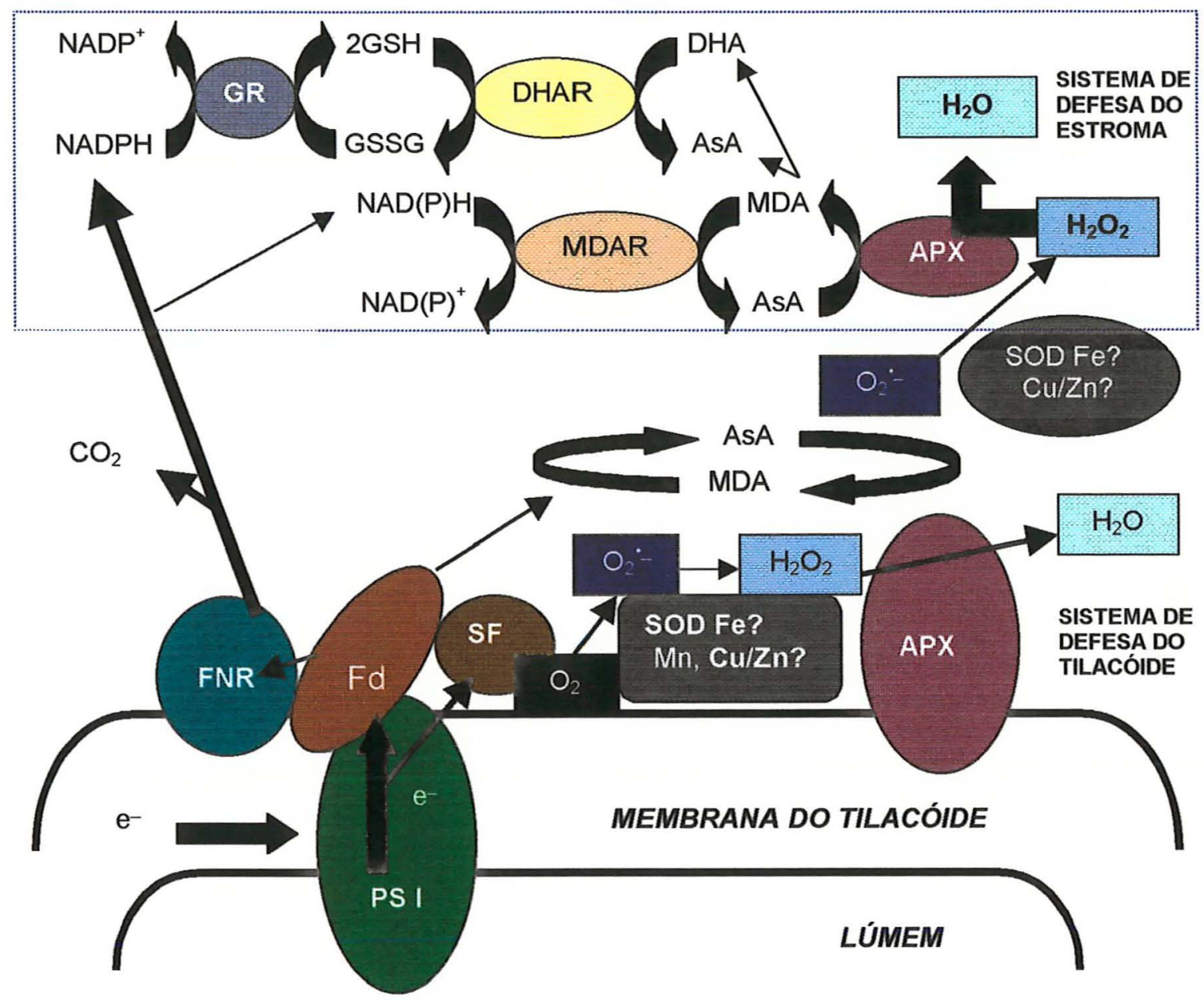

Figura 7: Mecanismo molecular do sistema fotorredutor do $\mathrm{O}_{2}$ à $\mathrm{H}_{2} \mathrm{O}$ no ciclo água-água e a microcompartimentalização das enzimas participantes, destacando-se o ciclo Halliwell-Asada (Alscher et al., 1998 e Asada, 1999). 


\subsection{Atividades de CAT, SOD e GR em plantas}

Como já discutido anteriormente, os organismos vivos principalmente os vegetais, estão sujeitos diariamente aos mais diversos fatores estressores ambientais. Estes fatores induzem a formação acelerada de ROS, que promovem, à nivel celular, estresse oxidativo imediato. As plantas, de uma maneira geral, para superar este problema possuem sistemas eficazes de defesa, dos quais as enzimas antioxidantes CAT, SOD e GR são algumas das mais importantes.

Várias pesquisas vêm sendo realizadas, no intuito de investigar as respostas destas enzimas à diferentes fatores estressores em diversas espécies de plantas cultivadas, sendo que alguns deles serão abordados à seguir.

Estudos relativos ao estresse salino, realizado em folhas de cultivares de tomates, indicaram que as plantas tolerantes à salinidade são mais protegidas da ação das ROS, devido ao fato de possuírem altos niveis de SOD, APX e CAT, neste órgão (Shalata \& Tal, 1998). Em contrapartida, partes aéreas de plântulas de arroz cultivadas in vitro, sugeriram a presença de mecanismos não enzimáticos contra o estresse oxidativo, pois a atividade de CAT, GR, Mn-SOD e Cu/Zn-SOD sofreram pequenos aumentos somente no início do estresse, e mesmo assim foram pequenos os danos oxidativos (Fadzilla et al., 1997).

Investigações sobre déficit hídrico foram realizadas em folhas de milho, onde as plantas tolerantes à seca apresentaram altos niveis de SOD, CAT, APX e GR, controlando os niveis de ROS no órgão (Del Longo et al., 1993), enquanto que as plantas de milho susceptiveis à seca, apresentaram baixos niveis enzimáticos e quando submetidas à ação de reguladores de crescimento de plantas (PGRs), apresentaram uma diminuição de perda de água, porém aumentaram $160 \%$ a atividade de CAT, devido a ação das PGRs (Todorov et al., 1998). 
Similarmente, plantas de trigo tolerantes à seca, apresentaram altos niveis de CAT e APX nas folhas (Sairam et al., 1998). Entretanto, em Calathea e Spathiphyllum micropopagadas e submetidas à deficit hídrico em ambiente in vivo, revelaram aumento na atividade de CAT e SOD, bem como alterações nas isoenzimas de SOD, no combate ao estresse oxidativo (Van Huylenbroeck et al., 1998).

Já, plantas de milho submetidas à alagamento, apresentaram elevação nas atividades de SOD, CAT, APX e GR nas folhas no periodo inicial de estresse, sendo que após este periodo, as atividades enzimáticas reduziram, principalmente da SOD, provocando danos irreversiveis às membranas (Yan et al., 1996).

Enzimas antioxidantes também foram estudadas em plantas de ervilha submetidas a ação do herbicida paraquat. Observou-se aumento nas atividades de GR, APX e SOD (Mn-SOD, Cu/Zn-SOD e Fe-SOD) nas folhas da cultivar resistente ao dióxido de enxofre $\left(\mathrm{SO}_{2}\right)$, que apresentaram grande resistência à este herbicida (Donahue et al., 1997). Similarmente, culturas de suspensões celulares de soja submetidas à ação do herbicida oxifluorfen, apresentaram elevação dos niveis de APX, GR e CAT (Knörzer et al., 1996).

Dai et al. (1997), estudaram a ação da radiação UV-B em folhas de plantas de arroz e observaram aumento nas atividades de SOD, CAT e APX no início do estresse, sendo diminuídas rapidamente durante a continuidade da exposição, concomitamente à desorganização do sistema de defesa não enzimático e danos oxidativos inevitáveis. Entretanto, em Arabidopsis thaliana expostas à UV-B e ozônio $\left(\mathrm{O}_{3}\right)$, foram observados aumento dos níveis de SOD (devido ao incremento da Cu/Zn-SOD) e GR, sugerindo que o sistema antioxidante atuante esteja representado pela SOD e enzimas do ciclo Halliwell-Asada (Rao et al., 1996).

Plantas de tabaco também foram investigadas em resposta à radiação- $\gamma$, sendo verificado nas folhas, incrementos nas atividades de SOD, 
CAT e principalmente de POX, que pode ser mais eficiente no combate aos $\mathrm{H}_{2} \mathrm{O}_{2}$ produzidos nesta espécie (Wada et al., 1998).

Outro fator ambiental estudado é o $\mathrm{CO}_{2}$, onde altos niveis foram testados em plantas de faia crescidas sob diferentes níveis de nutrição mineral. As atividades de CAT e SOD observadas nas folhas, foram sempre maiores sob condições ambientais do que sob altas concentrações de $\mathrm{CO}_{2}$, sendo incrementadas ainda mais sob níveis baixos de nutrição, concluindo-se que o estresse oxidativo está modulado pelo balanço de nitrogênio $(N)$ e carbono $(C)$ assimilados (Polle et al., 1997).

No entanto, foram estudados os efeitos da elevação dos niveis de $\mathrm{CO}_{2}$ e $\mathrm{O}_{3}$, em folhas de soja. $A$ atividade de CAT apresentou um declínio em detrimento à elevação de $\mathrm{CO}_{2}$ e $\mathrm{O}_{3}$, onde a alta concentração de $\mathrm{CO}_{2}$ aumentou a fotossíntese e diminuiu a fotorrespiração, sugerindo que $\circ \mathrm{CO}_{2}$ possa ser um verdadeiro promotor de produtividade (Booker et al., 1997). Já, o $\mathrm{O}_{3}$ diminuiu ambos os processos, inclusive sendo detectado alterações nas dimensões e destruição das membranas dos cloroplastos (Miyake et al., 1989).

Em pesquisas realizadas em plantas de cevada crescidas em alta concentração de $\mathrm{CO}_{2}$ e posteriormente transferidas para $\mathrm{O}_{3}$, ar, luz e sombra, observou-se um aumento dos niveis de CAT, nas folhas das plantas selvagens em todos os tratamentos e um pequeno aumento nas plantas mutantes sob Ar/luz e $\mathrm{O}_{3} /$ luz. Já nas raízes, a CAT diminuiu em todos os tratamentos. No caso da SOD (Cu/Zn-SOD e Mn-SOD), a atividade nas folhas e raízes aumentaram em todos os tratamentos e em relação a GR, a atividade nas folhas aumentou em todos os tratamentos, sendo atribuído ao $\mathrm{CO}_{2}$ importante papel na diminuição do estresse oxidativo cevada (Azevedo et al., 1998) e ao $\mathrm{O}_{3}$, ser responsável pela produção de ROS e ativação das enzimas antioxidantes (Sandermann et al., 1998).

$\mathrm{O}$ estresse por $\mathrm{O}_{3}$ foi estudado também em modelos unicelulares de Euglena, que revelaram altos níveis de AsA e APX, intrínsecos à espécie 
selvagem, responsáveis pela tolerância ao estresse (Bilodeau \& Chevrier, 1998).

Interações de incompatibilidade entre planta e patógeno conduzem a um fenômeno denominado de morte celular programada, ativado durante uma explosão oxidativa denominada de reação de hipersensibilidade, sendo necessária a atuação de sistemas antioxidantes para proteção do vegetal (Du \& Klessig, 1997 e Vanacker et al., 1998).

Estudos nesta linha foram desenvolvidos em folhas de cevada infectadas por fungo, indicando aumento nos niveis de CAT e SOD, na região do apoplasto das plantas resistentes e susceptiveis infectadas. A principal diferença observada foi em relação ao estoque de GSH no apoplasto das folhas, que foi aumentado no cultivar resistente e diminuído no susceptível após a inoculação, sendo a síntese e exportação de $\mathrm{GSH}$, considerado o principal mecanismo de resistência ao patógeno (Vanacker et al., 1998).

Outro mecanismo utilizado para determinação de resistência, tolerância e suscetibilidade à patógenos é a variação isoenzimática existente entre cultivares da mesma espécie. Onde, no caso da soja, foi possivel determinar a relação de várias linhagens com a doença do mosaico amarelo utilizando-se de padrões eletroforéticos das atividades de isoformas da CAT e POX (Malik et al., 1996).

Muitas espécies de dicotiledôneas possuem mecanismos de defesa ativados em resposta à patógenos, desencadeados por ácido salićlico (SA). Tenhaken \& Rübel (1997), estudaram o papel do SA relacionado à morte celular programada, em cultura de células de soja infectadas por bactérias. $O$ SA mostrou-se essencial para uma reação anterior à morte celular, portanto antes da explosão oxidativa e por isso, não influenciando na atividade das enzimas antioxidantes. No caso do tabaco, foi verificado a presença de proteínas especificas e enzimas antioxidantes, como a CAT, que se interagem ao SA. Caracterizando assim, o sistema antioxidante envolvido na morte celular programada (Du \& Klessig, 1997). 
Estresses por altas temperaturas, também foram relacionados aos sistemas antioxidantes, sendo que em plantas de feijão foram verificadas alterações nas enzimas antioxidantes das folhas, onde a SOD aumentou $70 \%$ nas plantas não aclimatadas e não variou naquelas que sofreram aclimatações e a CAT diminuiu em ambos os casos. Nas aclimatadas sob condições de estresse, o conteúdo de GSH aumentou cerca de $80 \%$, sugerindo que as plantas aclimatadas adquiriram maior tolerância à altas temperaturas (Edreva et al., 1998).

A tolerância à baixas temperaturas foi investigada em folhas de plantas de milho, que são consideradas muito sensiveis ao resfriamento (Doulis et al., 1997). Plantas previamente aclimatadas apresentaram maiores atividades da CAT e GR nas folhas durante o estresse e sob condições normais. A CAT parece representar papel principal na indução de tolerância e proteção contra o resfriamento (Prasad, T.K. 1997), embora relacionada à outros componentes como AsA, GSH, GR (Anderson et al., 1995) e PGRs que induzem aumento na SOD e APX, nas folhas e raizes sob baixas temperaturas (Pinhero et al., 1997). CAT-3 e POXs específicas representam papéis importantes na proteção das mitocôndrias, aos danos oxidativos, em plantas de milho aclimatadas (Prasad et al., 1995), como também em tecidos não fotossintetizantes (Anderson et al., 1995).

Plantas de feijão francês submetidas à aclimatação ao frio exibiram altas concentrações de AsA e GSH, aumento na atividade da SOD, APX e GR, nas folhas e diminuição da CAT (El-Saht, 1998). Diferentemente, em plantas de trigo, nenhuma alteração na atividade de $S O D$, tanto nas raízes como nas folhas foram notadas, enquanto que a CAT diminuiu em ambos os órgãos, principalmente nas plantas não aclimatadas, evidenciando as plantas aclimatadas como as mais protegidas contra as ROS (Scebba et al., 1998). Evidenciando-se ainda, que a aclimatação ao frio também aumenta a tolerância ao paraquat em plantas de batata, embora isto não seja um bom indicador da tolerância ao congelamento (Seppänen et al., 1998). 
Em contrapartida, a exposição de plantas de café ao frio não revelaram alterações das APX e CAT nas raízes. A atividade de GR diminuiu, afetando o ciclo Halliwell-Asada e interferindo na disponibilidade de $\mathrm{GSH}$, sendo atribuído aos compostos fenólicos a função de antioxidante celular (Queiroz et al., 1998), onde respostas similares foram observadas em culturas de parte aérea de arroz (Fadzilla et al., 1996). Entretanto, culturas de parte aérea de tabaco com sintomas de hiperidricidade (vitrificação) apresentaram altos niveis de SOD e CAT que foram diminuídos resfriando-se e adicionandose sacarose às placas, que aumentou o conteúdo de antioxidantes não enzimáticos, obtendo-se plantas de alta qualidade (Piqueras et al., 1998).

As ROS também podem influenciar nos processos de senescência e amadurecimento de frutos e plantas, induzindo respostas antioxidantes. Frutos de maça foram observados durante amadurecimento na própria árvore e em condições de estoque em baixas temperaturas. Nas árvores, os frutos apresentaram picos no conteúdo de etileno e nas atividades da SOD e CAT. Já, os frutos estocados, apresentaram o dobro do nível de CAT e aumento na concentração de etileno, revelando que o amadurecimento está ligado a interação de etileno com enzimas como a SOD e CAT (Masia, 1998). Da mesma forma, frutos de Cucumis melo, variedade tolerante ao armazenamento, apresentaram altos níveis de SOD e CAT, enquanto que a sensivel apresentou senescência precoce e baixos níveis enzimáticos (Lacan \& Baccou, 1998).

Sung (1996) estudou a senescência em sementes de soja no envelhecimento natural e acelerado, verificando que as condições impostas induziram inibição acentuada nas atividades da SOD, CAT, APX e POX. Similarmente, sementes de girassol apresentaram diminuição acentuada das atividades de CAT e GR, juntamente com o conteúdo de GSH, indicando que estes componentes representam um papel chave no vigor das sementes (Bailly et al., 1998). 
A senescência acelerada em plantas de milho, também foi estudada em inflorescências femininas, que revelaram um aumento na atividade da CAT, devido principalmente à elevação dos niveis da CAT-3 e nenhuma alteração nos niveis de SOD (Acevedo \& Scandalios, 1996). Já, pétalas de flores de Hemerocallis, em processo de senescência, apresentaram diminuição do conteúdo de AsA e baixos niveis de CAT e APX. Entretanto, apresentaram altos niveis de SOD e POXs específicas, porém pouco efetivas (Panavas \& Rubinstein, 1998). 


\section{MATERIAL E MÉTODOS}

O trabalho foi realizado no Laboratório de Genética Bioquímica de Plantas do Departamento de Genética da Escola Superior de Agricultura "Luiz de Queiroz" - Universidade de São Paulo.

\subsection{Cultivo das plantas}

Sementes de soja [Glycine max (L.) Merrill var. IAC-100] foram germinadas em papel de germinação umedecido em água destilada durante um período mínimo de 5 dias em uma sala de germinação sob condições controladas de temperatura e fotoperiodo (temperatura de $25^{\circ} \mathrm{C}$ e fotoperíodo de 14/10 h). Após a germinação, as plântulas foram transferidas para vasos plásticos que foram organizados sob um substrato de vermiculita em casa de vegetação (temperatura de $20^{\circ} \mathrm{C}$ a $28^{\circ} \mathrm{C}$ e fotoperíodo ambiente). Cada vaso recebeu em torno de 15 plantas distribuidas em placas de isopor $(1,5 \mathrm{~cm}$ de espessura) com diâmetro compativel à parte superior do vaso (Fig. 8). As plantas foram crescidas em solução nutritiva de HOAGLAND (Hoagland \& Arnon, 1951), em sistema de hidroponia (1,7 $L$ por vaso) e com as raízes mantidas sempre aeradas através de um compressor odontológico (SCHULZ I $1 \mathrm{HP}$ ). As plantas de soja foram mantidas nesta condição por 5 dias. Ao término deste período, procedeu-se a renovação da solução nutritiva, que foi então acrescida de $\mathrm{Cd}$ em concentrações variáveis de acordo com o experimento preliminar. 


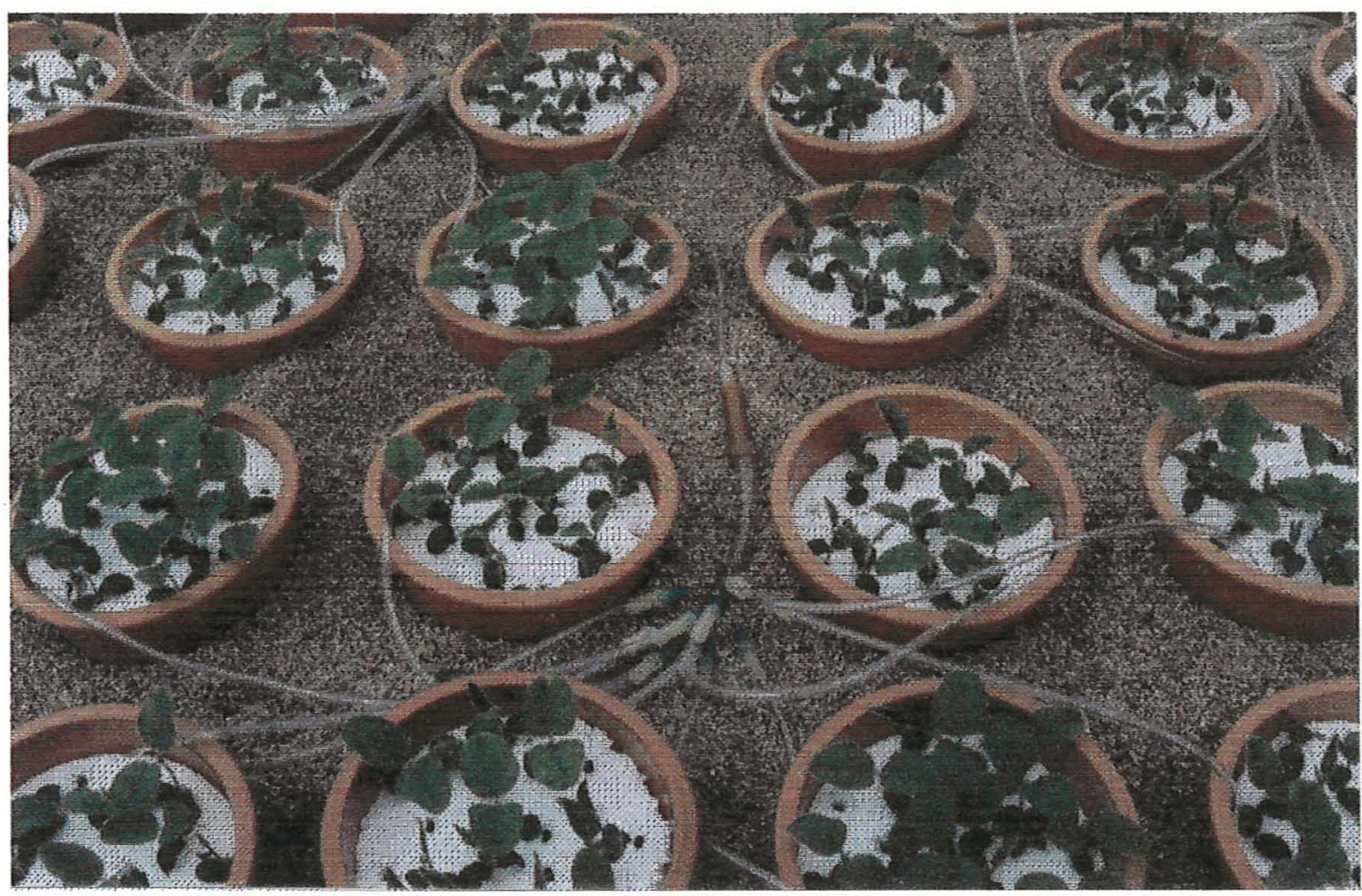

Figura 8: Esquema do cultivo de plântulas de soja em sistema de hidroponia, demonstrando a organização dos vasos no substrato, adequação das plântulas nas placas de isopor e sistema de aeração radicular.

\subsection{Experimento preliminar}

Um experimento preliminar foi realizado para determinação da concentração de $\mathrm{Cd}$ capaz de induzir inibição em torno de $80 \%$, do crescimento radicular em plântulas de soja crescidas em sistema de hidroponia, por um período de $120 \mathrm{~h}$ após a germinação, sob as concentrações de $0 \mathrm{mM}$ (controle); 0,5 mM; $1 \mathrm{mM} ; 2 \mathrm{mM}$ e $5 \mathrm{mM}$ de $\mathrm{CdCl}_{2}$.

As raízes das plântulas de soja foram medidas no início do experimento e com $120 \mathrm{~h}$ após a administração dos diferentes tratamentos. 


\subsection{Experimento principal}

Após a determinação da concentração tóxica de $\mathrm{Cd}$, as plantas de soja foram submetidas à tratamentos com concentrações de $0,01 \mathrm{mM}$ e $0,5 \mathrm{mM}$ de $\mathrm{CdCl}_{2}$ sempre em conjunto a um tratamento controle $(0 \mathrm{mM})$, por $48 \mathrm{~h}$. As coletas das plantas foram realizadas nos períodos de $0,3,6,9,12,15,18,21$, 24,36 e $48 \mathrm{~h}$, sendo as plantas divididas em folhas e raizes, congeladas em nitrogênio líquido e armazenadas em biofreezer à $-80^{\circ} \mathrm{C}$ até as extrações posteriores.

\subsection{Extração das enzimas}

A extração enzimática foi feita de folhas e raízes. Os tecidos foram homogeneizados em tampão fosfato de potássio $100 \mathrm{mM}(\mathrm{pH} \mathrm{7,5)}(4 \mathrm{~g}: 1 \mathrm{ml})$ contendo $1 \mathrm{mM}$ de EDTA, $3 \mathrm{mM}$ de DTT e $4 \%(\mathrm{p} / \mathrm{v})$ de PVPP. $O$ homogeneizado foi centrifugado à $10.000 \mathrm{rpm}$ por $30 \mathrm{~min}$ à $4^{\circ} \mathrm{C}$, utilizando-se uma centrífuga Beckmam modelo J2-MC. O sobrenadante foi coletado, dividido em aliquotas e congelados à $-80^{\circ} \mathrm{C}$, sendo utilizadas para os ensaios das atividades enzimáticas.

\subsection{Determinação de proteínas}

A concentração de proteina foi determinada em espectrofotômetro à $595 \mathrm{~nm}$ como descrito por Bradford (1976), utilizando-se o kit da Bio-Rad e BSA como padrão. 


\subsection{Atividade da catalase}

A atividade de CAT foi avaliada por dois métodos: espectrofotometria e PAGE.

\subsubsection{Atividade de CAT em espectrofotômetro}

A atividade de CAT foi determinada em espectofotômetro como descrito por Azevedo et al. (1998). O ensaio foi realizado à $25^{\circ} \mathrm{C}$ em uma solução contendo $1 \mathrm{ml}$ de tampão fosfato de potássio $100 \mathrm{mM}(\mathrm{pH} 7,5)$ acrescida de $25 \mu \mathrm{l}$ de $\mathrm{H}_{2} \mathrm{O}_{2}$ (solução $30 \%$ ). A reação foi iniciada pela adição de $25 \mu l$ de extrato vegetal e a atividade determinada monitorando-se a degradação de $\mathrm{H}_{2} \mathrm{O}_{2}$ à $240 \mathrm{~nm}$ (pico de absorção do $\mathrm{H}_{2} \mathrm{O}_{2}$ ), durante o período de 1 minuto e dosagem contínua em intervalos de 1 segundo. Os resultados foram expressos em $\mu \mathrm{mol} / \mathrm{min} / \mathrm{mg}$ prot.

\subsubsection{Atividade de CAT em PAGE}

A atividade de CAT em PAGE não-desnaturante, foi determinada segundo Woodbury et al. (1971). Os extratos vegetais tiveram suas proteínas separadas em PAGE não-desnaturante numa concentração de $8 \%$ de poliacrilamida com um gel de empilhamento contendo $4 \%$. Os tampões e géis de eletroforese foram preparados como descrito por Laemmli (1970).

A eletroforese foi conduzida a $4^{\circ} \mathrm{C}$ em corrente constante de 30 mA placa em um tempo médio de corrida de $12 \mathrm{~h}$. Foram aplicados aos géis amostras de padrão de CAT de fígado bovino (2 unidades) e $30 \mu \mathrm{g}$ de proteína dos extratos de raízes e folhas. A revelação foi feita incubando-se o gel por 10 minutos em solução $0,003 \%$ de $\mathrm{H}_{2} \mathrm{O}_{2}$ e, posteriormente, em uma solução $1 \%$ $(p / v)$ de $\mathrm{FeCl}_{3}$ e $1 \%(\mathrm{p} / \mathrm{v})$ de $\mathrm{K}_{3} \mathrm{Fe}\left(\mathrm{CN}_{6}\right) 1 \%(\mathrm{p} / \mathrm{v})$, por 10 minutos. 


\subsection{Atividade da superóxido dismutase}

$A$ atividade de SOD e suas isoformas, em ambos os tecidos de soja, foram determinadas em PAGE não-desnaturante.

\subsubsection{Atividade de SOD em PAGE}

PAGE não-desnaturante para determinação da atividade de SOD foi conduzida nas mesmas condições como descrito para CAT (3.6.2.).

Foram aplicados aos géis amostras de padrão de SOD de figado bovino ( 2 unidades), $150 \mu \mathrm{g}$ de proteína do extrato de folhas e $45 \mu \mathrm{g}$ do extrato de raízes. Após um tempo médio de $8 \mathrm{~h}$ para eletroforese, os géis foram lavados em água destilada e incubados no escuro por 30 minutos em temperatura ambiente, em uma solução contendo $100 \mathrm{mM}$ de tampão fosfato de potássio ( $\mathrm{pH} 7.8$ ), $1 \mathrm{mM}$ de EDTA, $0,05 \mathrm{mM}$ de riboflavina, $0,1 \mathrm{mM}$ de NBT e $0,3 \%(v / v)$ de TEMED.

Ao final deste período, a solução foi retirada e os géis mergulhados em água deionizada e mantidos sob iluminação até o aparecimento de bandas claras (sem cor) de atividade de SOD em relação a coloração púrpura dos géis. A reação foi interrompida incubando-se o gel em uma solução $7 \%(\mathrm{v} / \mathrm{v})$ de ácido acético por 15 minutos.

\subsubsection{Determinação das isoenzimas de SOD}

Para a determinação das isoformas de SOD, as raizes e folhas foram submetidas a PAGE não-desnaturante em mini-gel (8\%). A eletroforese foi conduzida a $4^{\circ} \mathrm{C}$ com uma corrente constante de $15 \mathrm{~mA} / \mathrm{placa}$ por $4 \mathrm{~h}$. A amostra foi aplicada no gel em concentrações de $1540 \mu \mathrm{g}$ e $200 \mu \mathrm{g}$ de proteina de extratos de folha e raiz, respectivamente. 
Ao final da eletroforese, o gel foi dividido verticalmente em três partes iguais. A primeira parte foi revelada para atividade de SOD como acima (3.7.1.), a segunda e a terceira parte foram incubadas por 20 minutos em 100 $\mathrm{mM}$ de tampão fosfato de potássio ( $\mathrm{pH} \mathrm{7.8)} \mathrm{contendo} 2 \mathrm{mM} \mathrm{KCN} \mathrm{e} 100 \mathrm{mM}$ de tampão fosfato de potássio ( $\mathrm{pH} 7.8$ ) contendo $5 \mathrm{mM}$ de $\mathrm{H}_{2} \mathrm{O}_{2}$, respectivamente. Após este periodo, ambas as partes foram lavadas e reveladas para atividade

de SOD. $O$ pré-tratamento dos géis em $\mathrm{H}_{2} \mathrm{O}_{2}$ e $\mathrm{KCN}$ antes da revelação de SOD permitiu a classificação das isoenzimas da SOD em Cu/Zn-SOD, Fe-SOD ou Mn-SOD. Mn-SOD é resistente à ambos inibidores, Fe-SOD é resistente ao $\mathrm{KCN}$ e inibida por $\mathrm{H}_{2} \mathrm{O}_{2}$ e $\mathrm{Cu} / \mathrm{Zn}-\mathrm{SOD}$ é inibida por ambos inibidores (Azevedo et al., 1998).

\subsection{Atividade da glutationa redutase}

A atividade de GR foi determinada pelo método espectrofotométrico.

\subsubsection{Atividade de GR em espectofotômetro}

A atividade de GR foi determinada como descrito por Azevedo et al. (1998). A atividade enzimática foi determinada colorimetricamente a $30^{\circ} \mathrm{C} \mathrm{em}$ uma solução consistindo de $1 \mathrm{ml}$ de tampão fosfato de potássio $100 \mathrm{mM}(\mathrm{pH}$ 7,5) contendo $1 \mathrm{mM}$ de DTNB, $1 \mathrm{mM}$ de GSSG e 0,1 mM de NADPH. A reação foi iniciada com a adição de $50 \mu l$ de extrato vegetal. $A$ taxa de redução da GSSG foi monitorada pelo aumento, à cada segundo, na absorbância a $412 \mathrm{~nm}$ por 1 minuto. Os valores de atividade foram expressos em $\mu \mathrm{mol} / \mathrm{min} / \mathrm{mg}$ prot. 


\subsection{Análise estatística}

Os experimentos foram repetidos três vezes. Os dados foram estatisticamente analisados em cada experimento e os resultados expressos pelas médias e desvio padrão $( \pm S D)$ de 3 repetições independentes para as medições de comprimento da parte aérea, da raiz e das atividades de CAT e GR. 


\section{RESULTADOS}

\subsection{Determinação da concentração fitotóxica de $\mathrm{Cd}$}

Sementes de soja foram germinadas, transferidas em solução nutritiva e submetidas a um periodo de crescimento de $120 \mathrm{~h}$ sob diferentes concentrações de Cd. Como pode ser observado na Fig. 9, a adição de Cd resultou em uma inibição do crescimento radicular mesmo na concentração mais baixa utilizada $(0,5 \mathrm{mM})$.

\subsection{Desenvolvimento das plântulas}

As plântulas de soja submetidas à $0,5 \mathrm{mM}$ de $\mathrm{CdCl}_{2}$ apresentaram acentuada inibição no desenvolvimento de suas partes aéreas e raízes, além de indícios de clorose em relação às plantas controles (Fig. 10).

\subsubsection{Crescimento da parte aérea}

A inibição do crescimento da parte aérea das plântulas de soja foi evidenciada no tratamento com concentração de $0,5 \mathrm{mM}$ de $\mathrm{CdCl}_{2}$ após $48 \mathrm{~h}$ de exposição, sendo que a concentração de $0,01 \mathrm{mM}$ não apresentou diferenças significativas em relação às plantas controles (Fig. 11). 


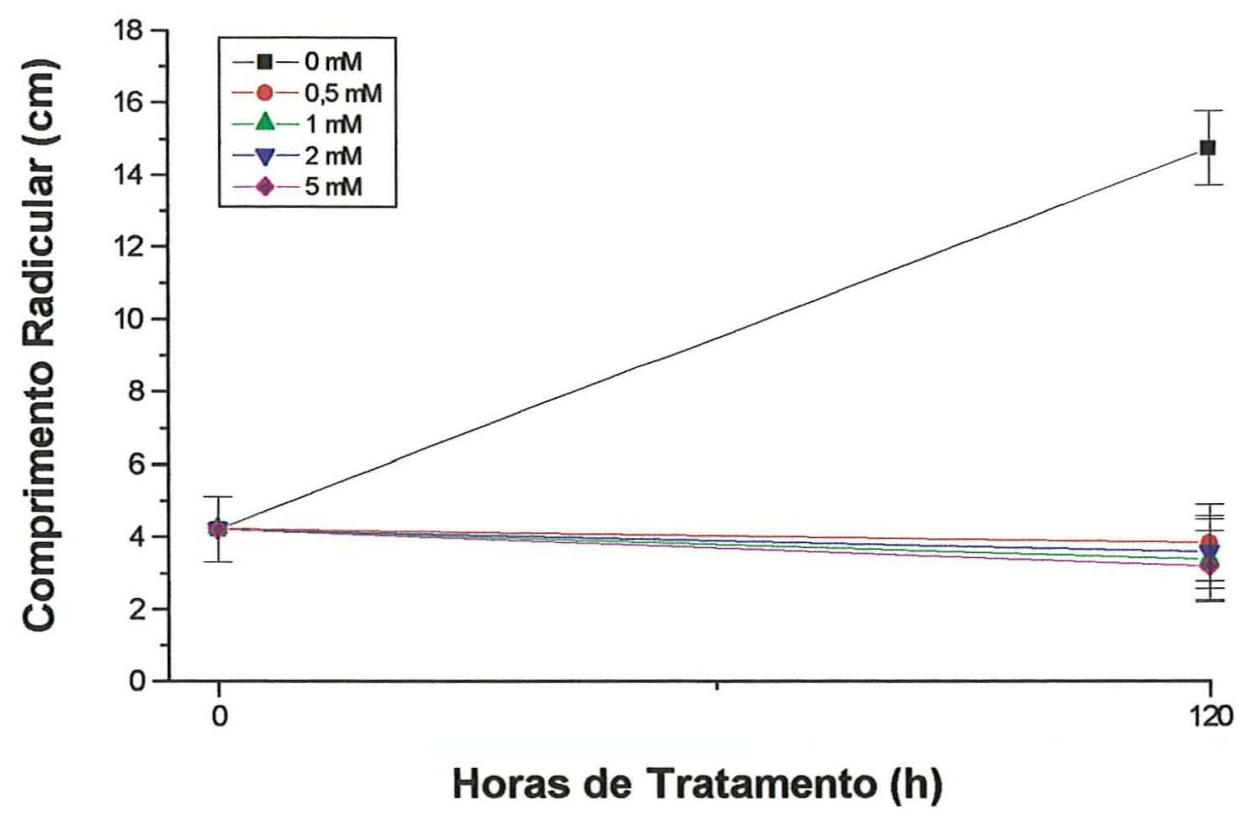

Figura 9: Efeito do $\mathrm{Cd}$ no crescimento radicular em plântulas de soja submetidas às concentrações de 0 (controle); 0,$5 ; 1 ; 2$ e $5 \mathrm{mM}$ de $\mathrm{CdCl}_{2}$ pelo período de $120 \mathrm{~h}$ de tratamento.

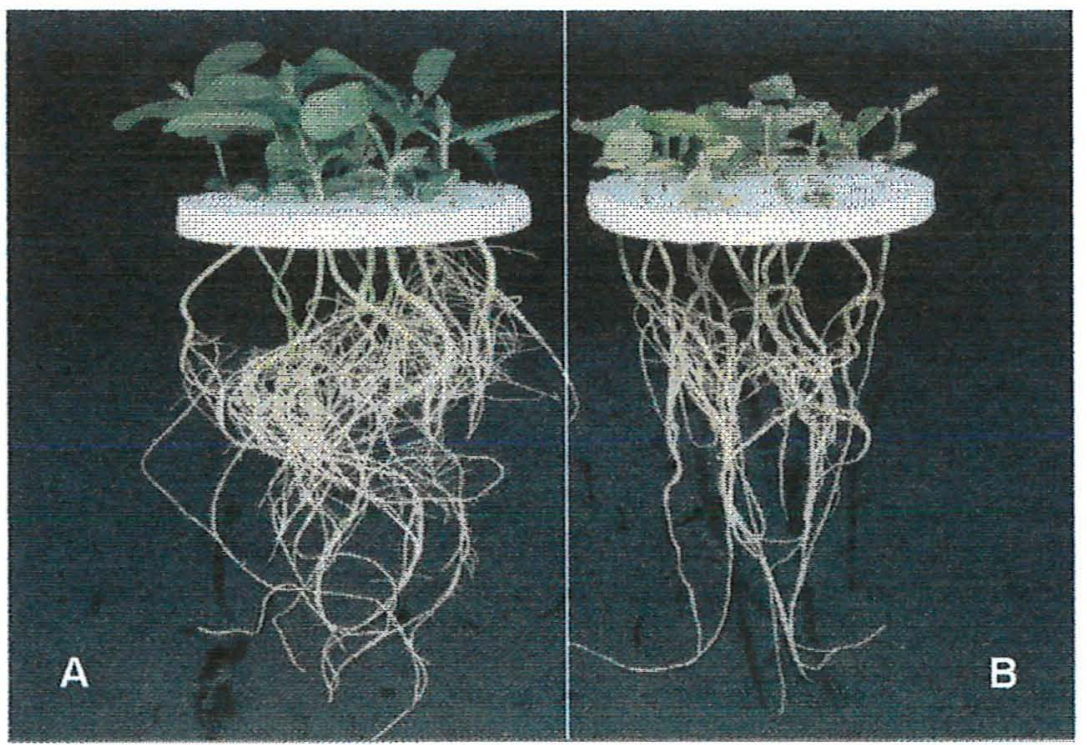

Figura 10: Efeito do Cd no desenvolvimento de plântulas de soja que foram crescidas por 5 dias em solução nutritiva e submetidas às concentrações controle (A) e 0,5 mM de $\mathrm{CdCl}_{2}$ (B), por mais $120 \mathrm{~h}$. 


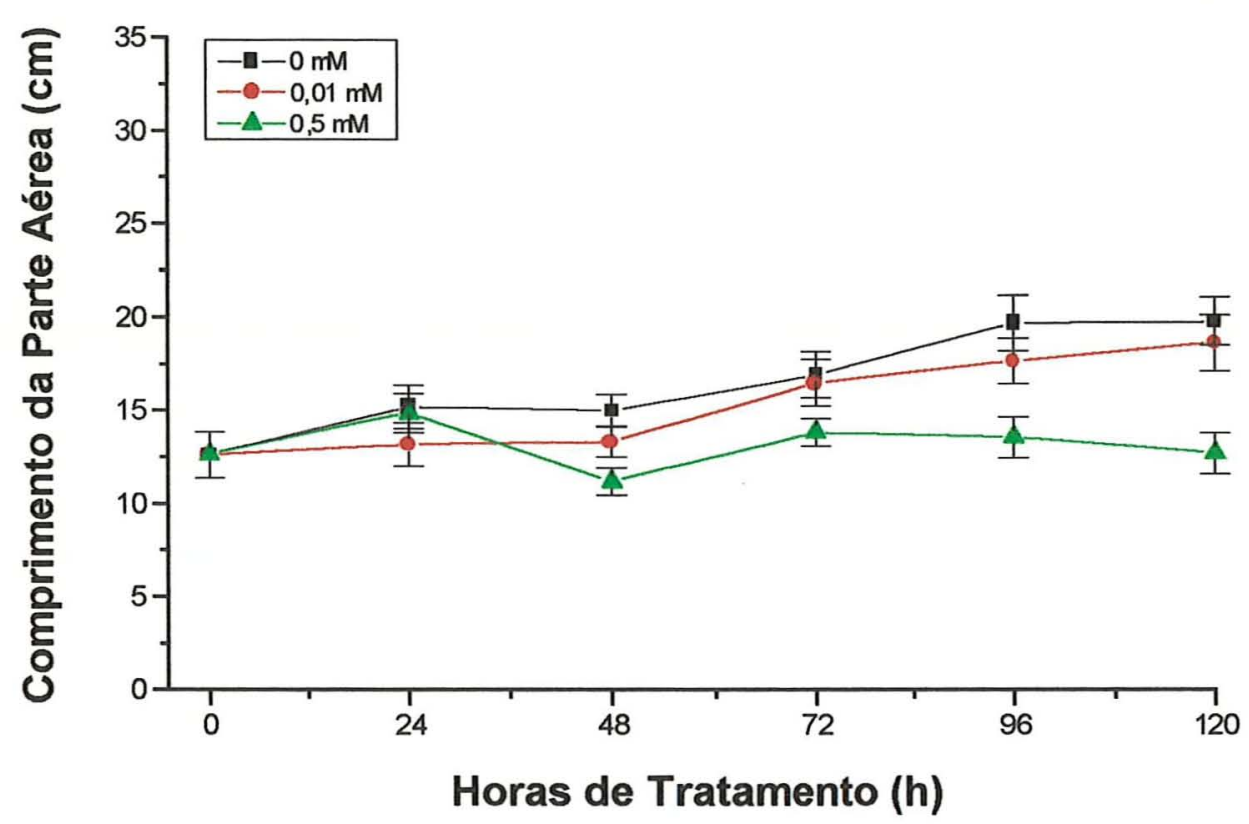

Figura 11: Efeito do Cd no desenvolvimento da parte aérea de plântulas de soja submetidas à diferentes concentrações de $\mathrm{CdCl}_{2}$.

\subsubsection{Crescimento da Raiz}

O crescimento da raiz foi inibido significativamente após $96 \mathrm{~h}$ de tratamento das plântulas de soja à concentração de $0,5 \mathrm{mM} \mathrm{CdCl}$, enquanto que não apresentou variação, em relação às plantas controle, a concentração de $0,01 \mathrm{mM} \mathrm{CdCl}_{2}$ (Fig. 12). 


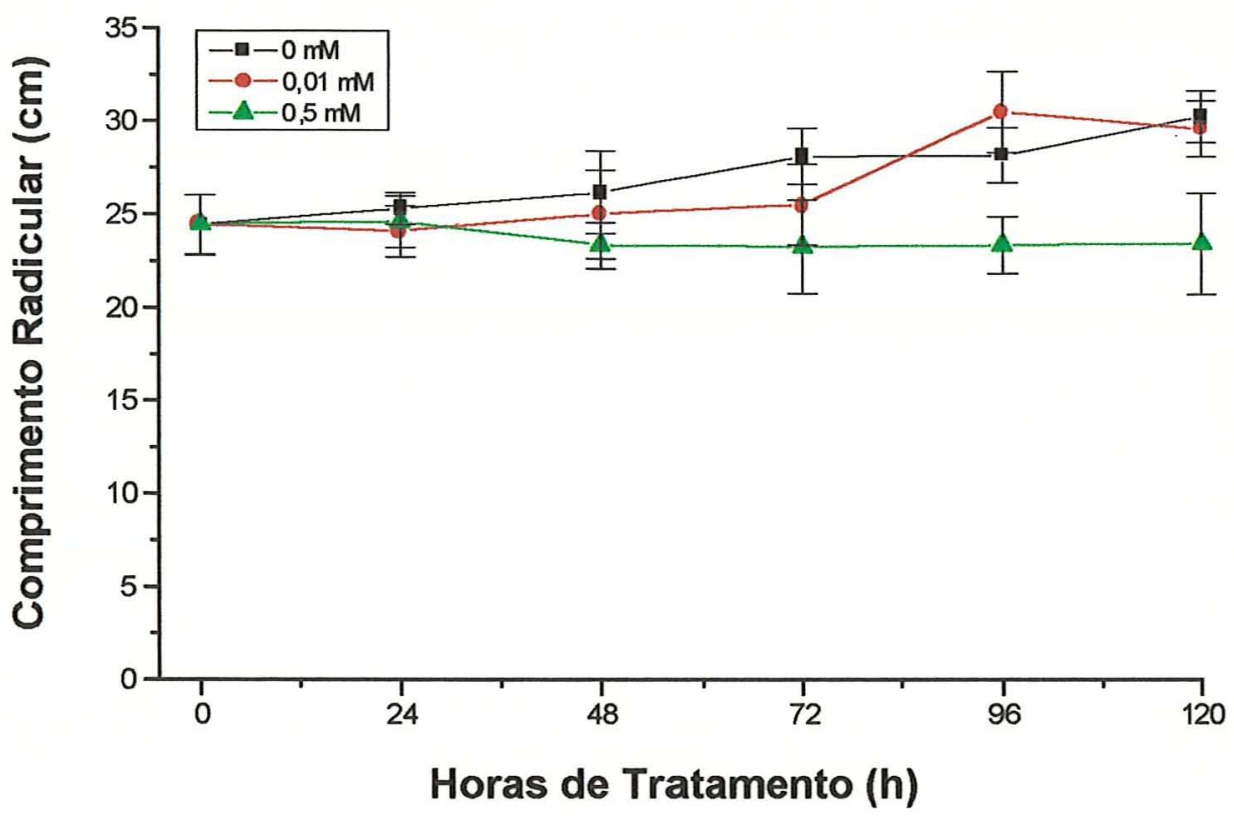

Figura 12: Efeito do $\mathrm{Cd}$ no desenvolvimento da raiz de plântulas de soja submetidas à diferentes concentrações de $\mathrm{CdCl}_{2}$.

\subsection{Atividade da CAT}

As atividades de enzimas antioxidantes foram determinadas em raiz e folha de plantas de soja submetidas à crescimento em presença de $\mathrm{CdCl}_{2}$.

A atividade da CAT de folhas não apresentou variações significativas durante o período de tratamento em relação ao controle, a não ser por uma ligeira diminuição de atividade à partir de $36 \mathrm{~h}$ em ambos tratamentos realizados. Entretanto, de maneira geral, as variações de atividade nos tratamentos e controle, ao longo do tempo sugerem um padrão idêntico com mínima variação de atividade de CAT, principalmente considerando-se que os 
controles também apresentaram variações entre os períodos de tratamento (Fig. 13).

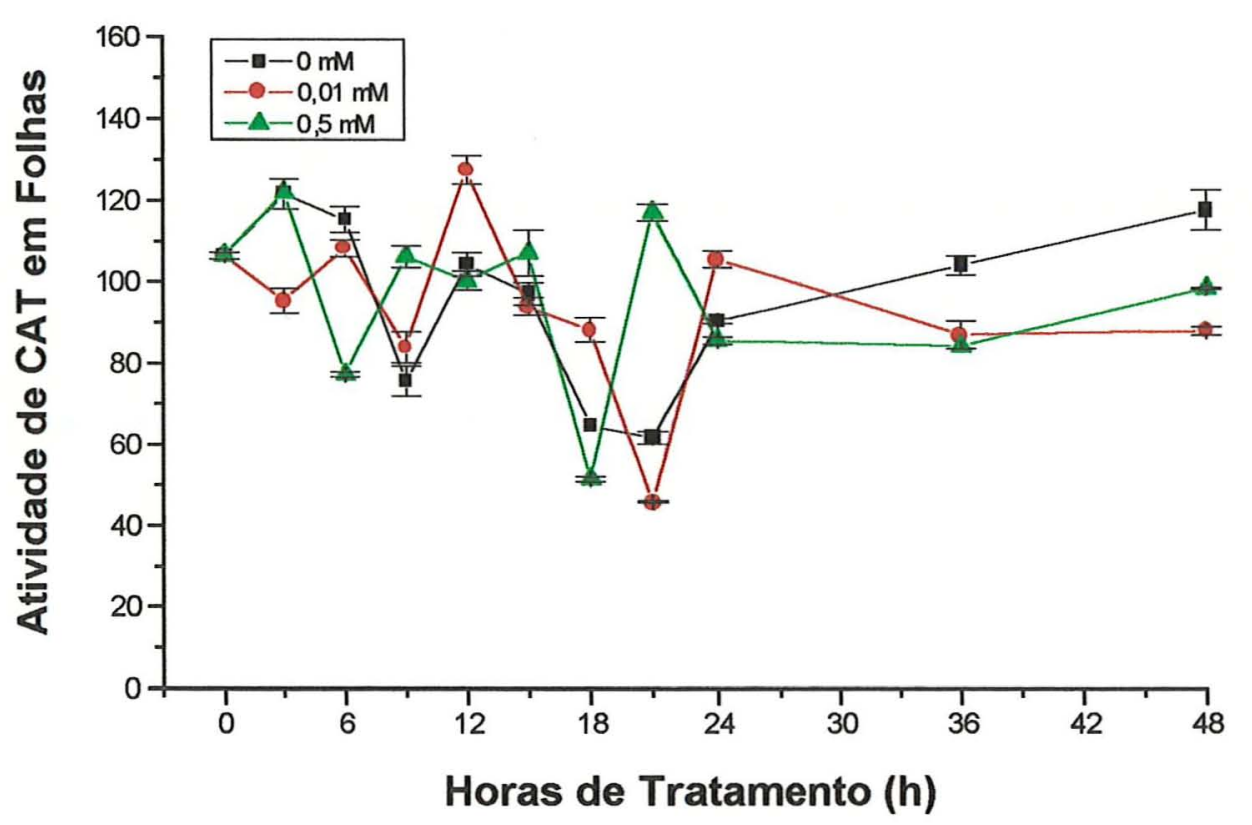

Figura 13: Atividade específica de CAT ( $\mu \mathrm{mol} / \mathrm{min} / \mathrm{mg}$ prot) em folhas de plântulas de soja submetidas à diferentes concentrações de $\mathrm{CdCl}_{2}$.

Em relação às raízes, a atividade da CAT apresentou uma elevação após $21 \mathrm{~h}$ de tratamento na concentração de $0,50 \mathrm{mM}$ de $\mathrm{CdCl}_{2}$, comparado ao tratamento de $0,01 \mathrm{mM}$ e controle (Fig. 14). Porém, as variações de atividade nos tratamentos e controle, durante o período experimental revelaram existir um padrão semelhante de atividade de CAT, com mínima variação ao longo do tempo, assim como o observado em folhas (Fig. 13). 


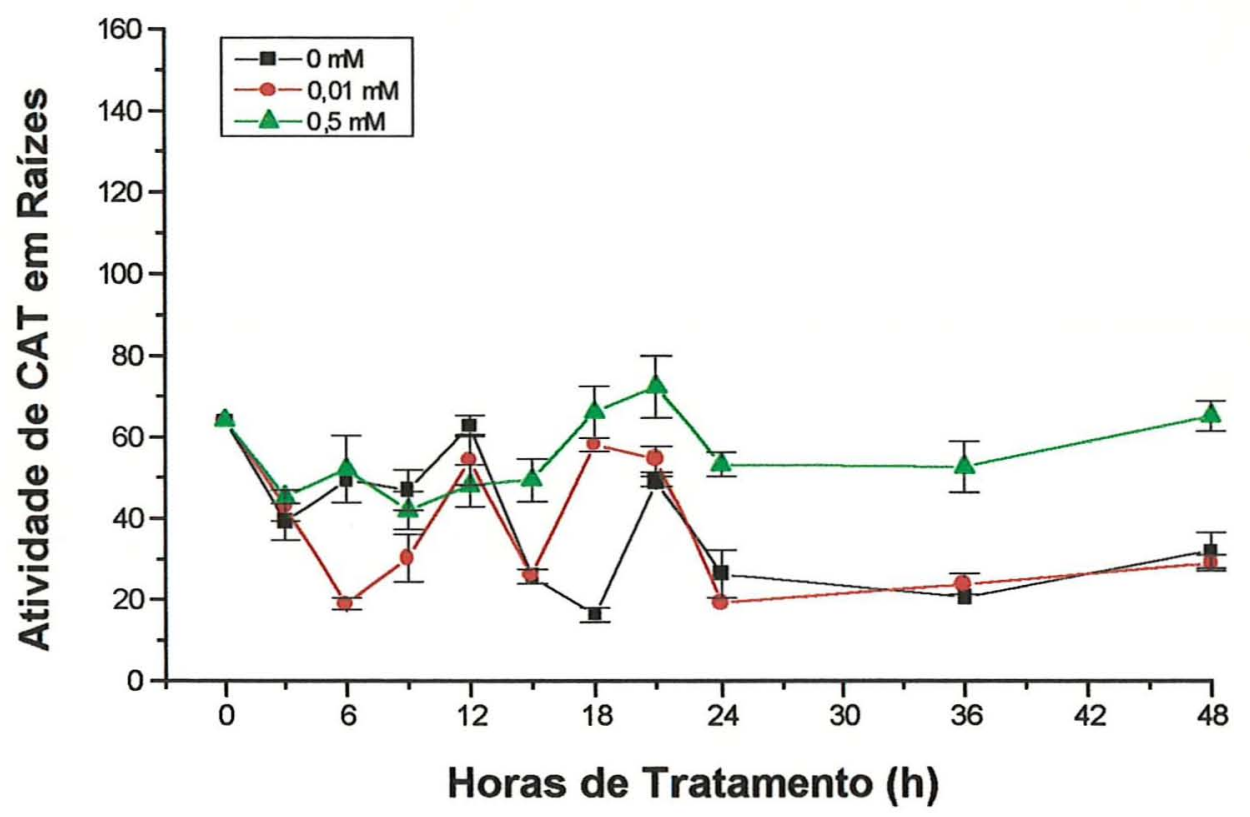

Figura 14: Atividade específica de CAT ( $\mu \mathrm{mol} / \mathrm{min} / \mathrm{mg}$ prot) em raízes de plântulas de soja submetidas à diferentes concentrações de $\mathrm{CdCl}_{2}$.

Além deste procedimento de determinação da atividade de CAT, foi também utilizado PAGE não-desnaturante com coloração para atividade de CAT. Tanto para as folhas como para as raízes a atividade de CAT apresentou características distintas. No que diz respeito às folhas, não foram evidenciadas isoformas distintas da CAT, assim como alterações significativas nas atividades enzimáticas entre os tratamentos aplicados. Excetuando-se uma pequena diminuição somente nas amostras de plantas de $18 \mathrm{~h}$ de tratamento sob $0,5 \mathrm{mM}$ de $\mathrm{CdCl}_{2}$ e um padrão diferenciado de banda na amostra controle (0 h - 0 mM CdCl 2$)$ (Fig. 15).

Curiosamente, o procedimento de revelação de atividade de CAT resultou no aparecimento de uma banda de coloração verde escura não 
específica, identificada como uma "chlorophyll-binding proteins" (X, Fig. 15) (P. Lea, comunicação pessoal).

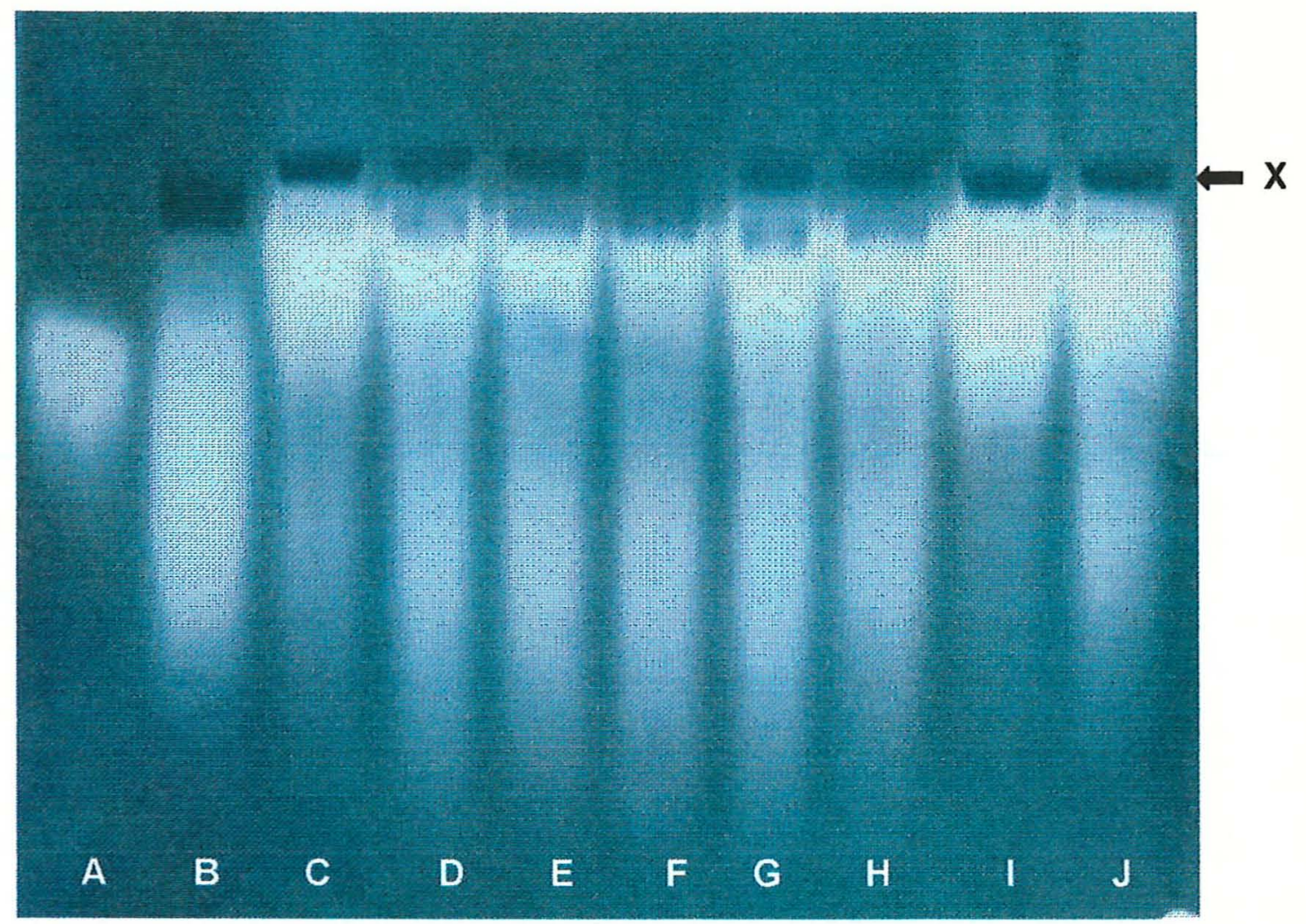

Figura 15: Atividade de CAT em folhas de plântulas de soja submetidas à diferentes concentrações de $\mathrm{CdCl}_{2}$, determinada em PAGE não-desnaturante. (A) amostra padrão de CAT bovina, (B) $0 \mathrm{~h}-0 \mathrm{mM}$ (controle), (C) $9 \mathrm{~h}-0 \mathrm{mM}$, (D) $9 \mathrm{~h}-0,5 \mathrm{mM}$, (E) $18 \mathrm{~h}-0 \mathrm{mM}$, (F) $18 \mathrm{~h}-0,5 \mathrm{mM}$, (G) $24 \mathrm{~h}-0 \mathrm{mM}$, (H) $24 \mathrm{~h}$ $-0,5 \mathrm{mM}$, (I) $48 \mathrm{~h}-0 \mathrm{mM}$ e (J) $48 \mathrm{~h}-0,5 \mathrm{mM}$.

As raízes apresentaram aumento nas atividades de CAT nas concentrações de $0,5 \mathrm{mM}$ de $\mathrm{CdCl}_{2}$ nos tratamentos de 9,18 e $24 \mathrm{~h}$ em relação às plantas controles (Fig. 16). 


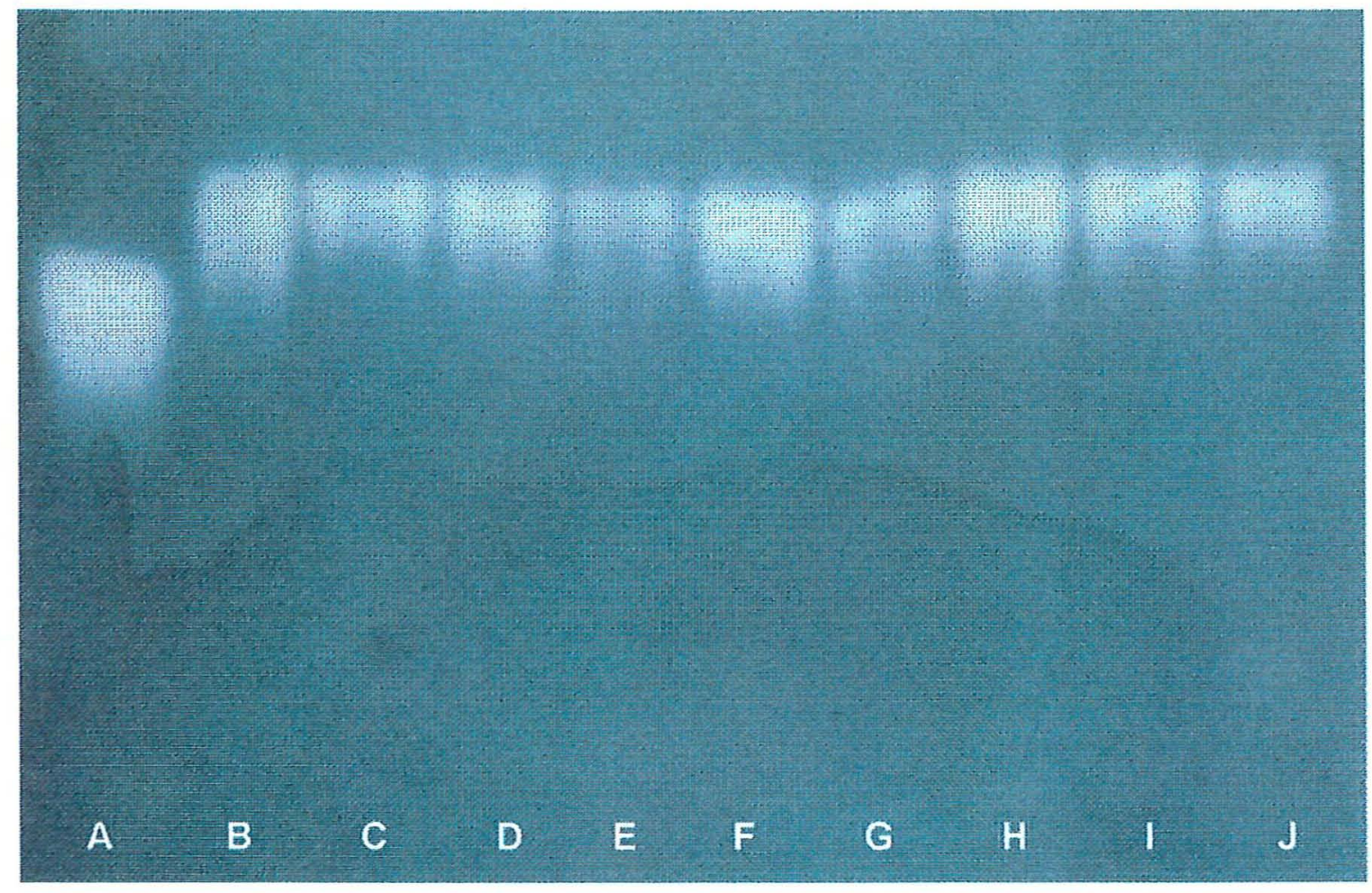

Figura 16: Atividade de CAT em raízes de plântulas de soja submetidas à diferentes concentrações de $\mathrm{CdCl}_{2}$, determinada em PAGE não-desnaturante. (A) amostra padrão de CAT bovina, (B) $0 \mathrm{~h}-0 \mathrm{mM}$ (controle), (C) $9 \mathrm{~h}-0 \mathrm{mM}$, (D) $9 \mathrm{~h}-0,5 \mathrm{mM}$, (E) $18 \mathrm{~h}-0 \mathrm{mM}$, (F) $18 \mathrm{~h}-0,5 \mathrm{mM}$, (G) $24 \mathrm{~h}-0 \mathrm{mM}$, (H) $24 \mathrm{~h}$ $-0,5 \mathrm{mM}$, (I) $48 \mathrm{~h}-0 \mathrm{mM}$ e (J) $48 \mathrm{~h}-0,5 \mathrm{mM}$.

\subsection{Atividade da SOD}

Os estudos da atividade de SOD indicaram a presença de até sete isoformas da enzima em folhas de plântulas de soja. Pela Fig. 17 pode-se verificar que não ocorreram diferenças entre os níveis de atividade, assim como de ativação ou inibição específica entre as isoformas em todos os tratamentos, avaliados entre si e em relação ao controle. 


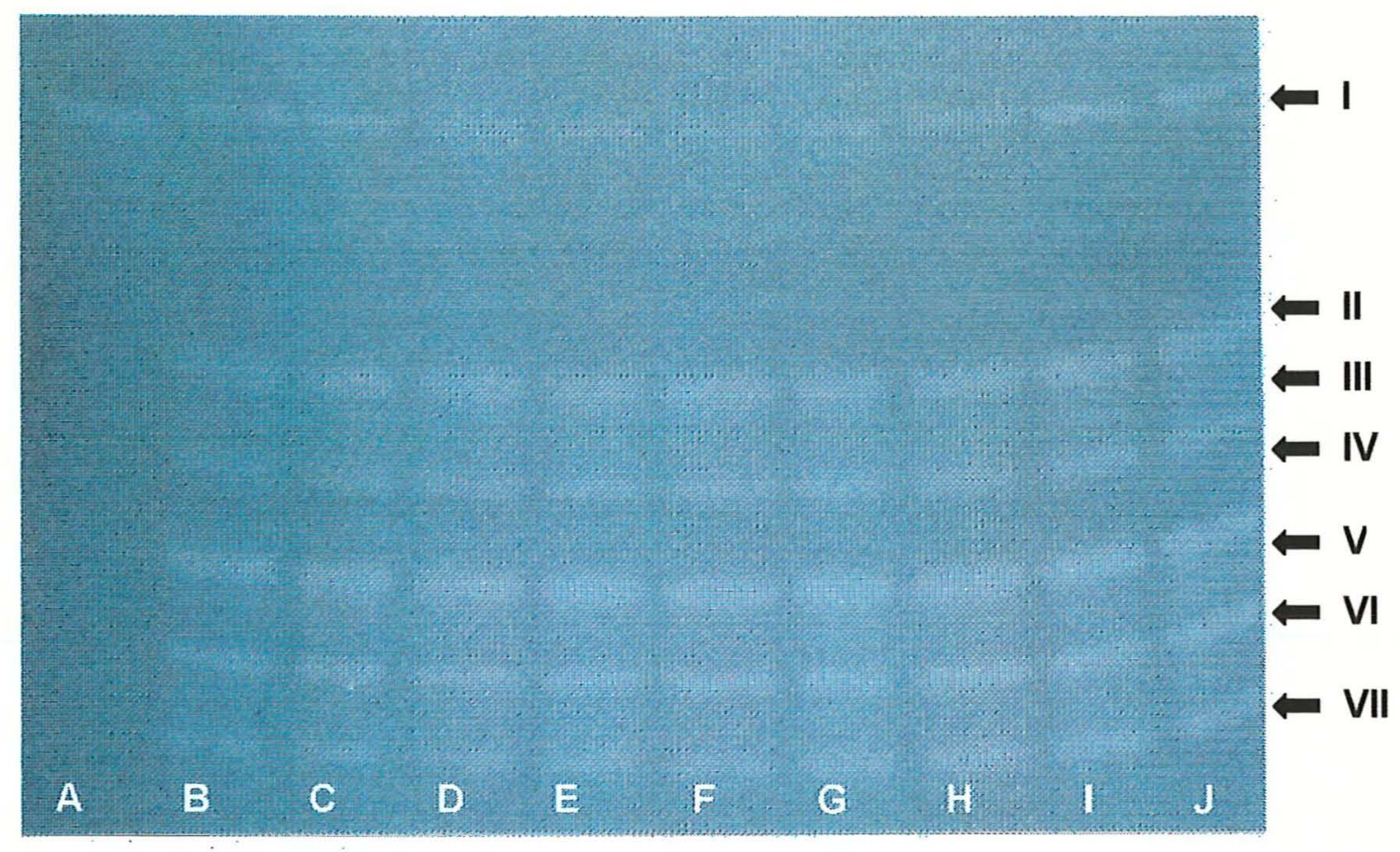

Figura 17: Atividade de SOD em folhas de plântulas de soja submetidas à diferentes concentrações de $\mathrm{CdCl}_{2}$, determinada em PAGE não-desnaturante. (A) amostra padrão de SOD de fígado bovino, (B) $0 \mathrm{~h}-0 \mathrm{mM}$ (controle), (C) $9 \mathrm{~h}$ - 0 mM, (D) $9 \mathrm{~h}-0,5 \mathrm{mM}$, (E) $18 \mathrm{~h}-0$ mM, (F) $18 \mathrm{~h}-0,5 \mathrm{mM}$, (G) $24 \mathrm{~h}-0 \mathrm{mM}$, (H) $24 \mathrm{~h}-0,5 \mathrm{mM}$, (I) $48 \mathrm{~h}-0 \mathrm{mM}$ e (J) $48 \mathrm{~h}-0,5 \mathrm{mM}$.

Diferentemente, os estudos das raízes demonstraram oito isoformas distintas de SOD que também, não variaram em relação aos tratamentos avaliados (Fig. 18). A posição indicada da isoforma $\mathrm{I}^{\mathrm{A}}$ é hipotética nesta figura, porém característica da raiz conforme indicada na Fig. 20 e a isoforma III, menos evidenciada, também é característica em todos os tratamentos. Em relação às atividades da enzima, nenhuma variação entre os diferentes tratamentos e controles foram detectadas. 


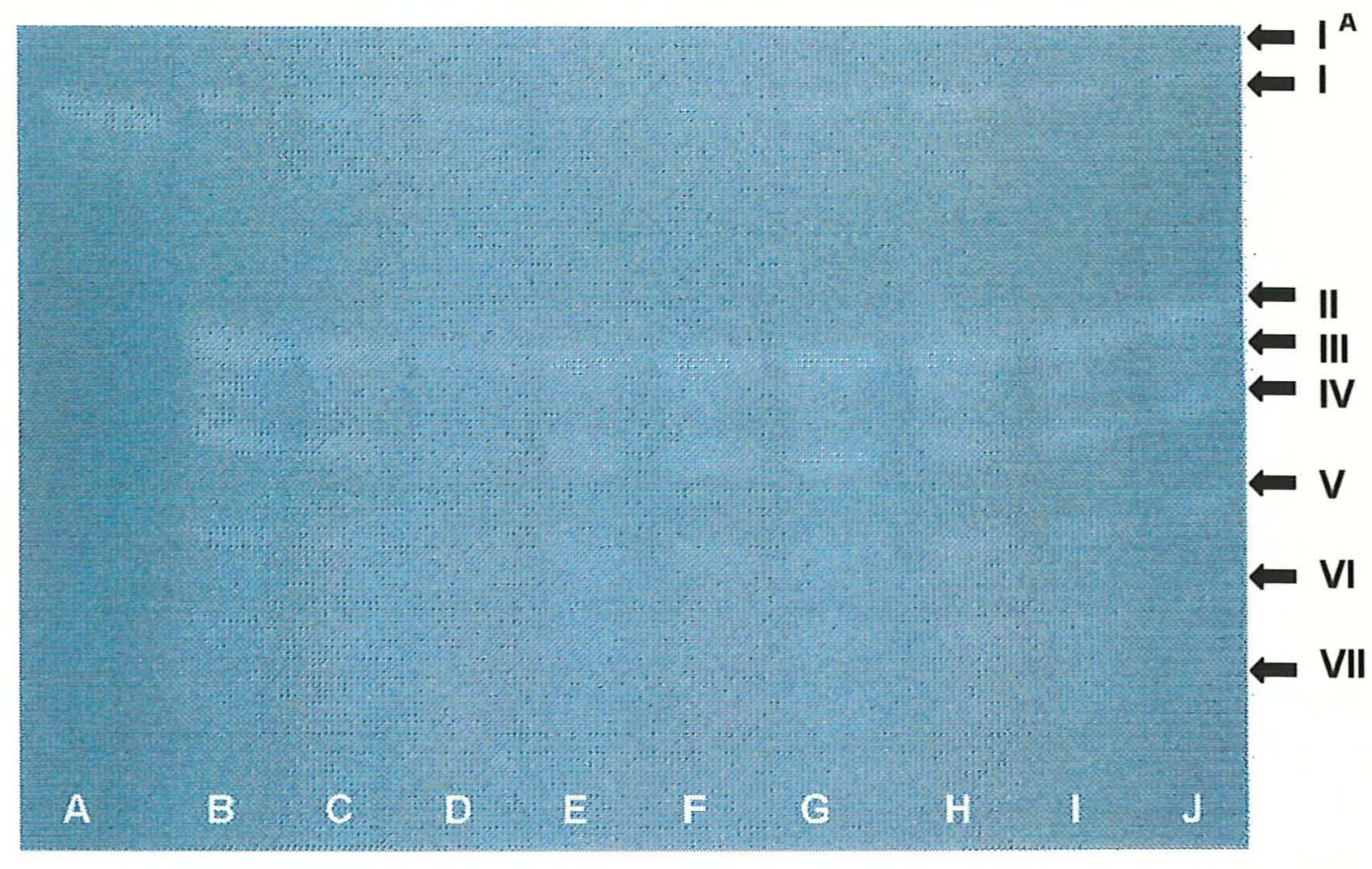

Figura 18: Atividade de $S O D$ em raízes de plântulas de soja submetidas à diferentes concentrações de $\mathrm{CdCl}_{2}$, determinada em PAGE não-desnaturante. (A) amostra padrão de SOD de fígado bovino, (B) $0 \mathrm{~h}-0 \mathrm{mM}$ (controle), (C) $9 \mathrm{~h}$ - 0 mM, (D) $9 \mathrm{~h}-0,5$ mM, (E) $18 \mathrm{~h}$ - 0 mM, (F) $18 \mathrm{~h}$ - 0,5 mM, (G) $24 \mathrm{~h}-0$ mM, (H) $24 \mathrm{~h}-0,5 \mathrm{mM}$, (I) $48 \mathrm{~h}-0 \mathrm{mM}$ e (J) $48 \mathrm{~h}-0,5 \mathrm{mM}$.

\subsubsection{Isoformas da SOD}

Amostras de folhas de soja controle $\left(0 \mathrm{mM}\right.$ de $\mathrm{CdCl}_{2}$ ) foram utilizadas para a caracterização das diferentes bandas observadas nos experimentos (Fig. 19). Dentre as sete isoenzimas de SOD observadas, uma (I) foi caracterizada como Mn-SOD e as outras (II, III, IV, V, VI e VII) izoenzimas demonstraram serem todas Cu/Zn-SOD. Nenhuma Fe-SOD foi encontrada neste órgão. 


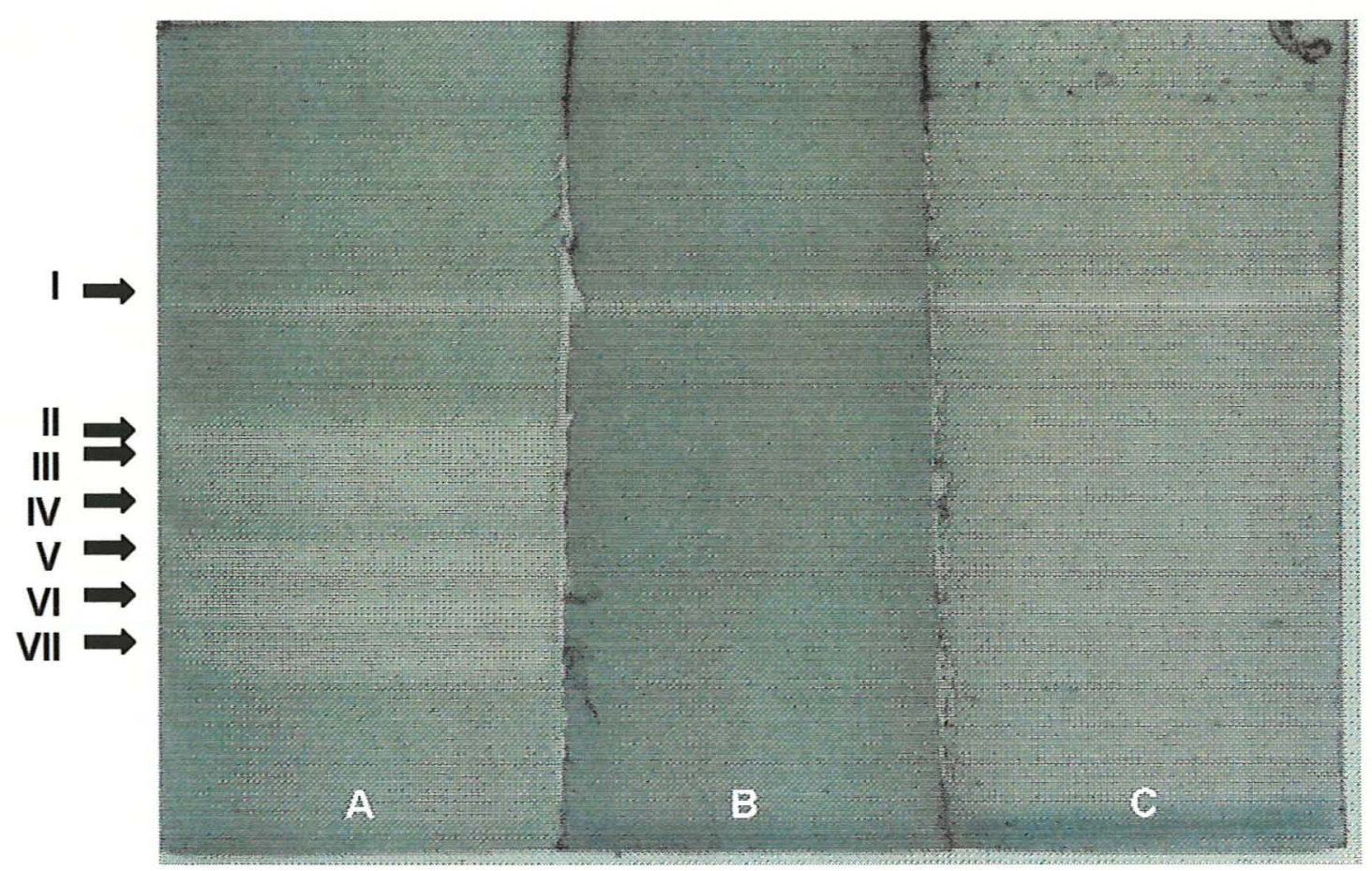

Figura 19: Caracterização das isoenzimas de SOD presentes em folhas de soja em PAGE não-desnaturante. Em (A) controle padrão de atividade, (B) controle $+\mathrm{H}_{2} \mathrm{O}_{2}$ e (C) controle $+\mathrm{KCN}$.

Em relação às raízes, um padrão diferenciado de isoenzimas foi observado, com oito isoformas de SOD distintas, onde as duas primeiras isoformas $\left(I^{\mathrm{A}}\right.$ e I) foram caracterizadas como Mn-SOD e as outras seis isoformas (II, III, IV, V, VI e VII) se apresentaram como Cu/Zn-SOD (Fig. 20) e também não foi observada nenhuma isoforma de Fe-SOD. 


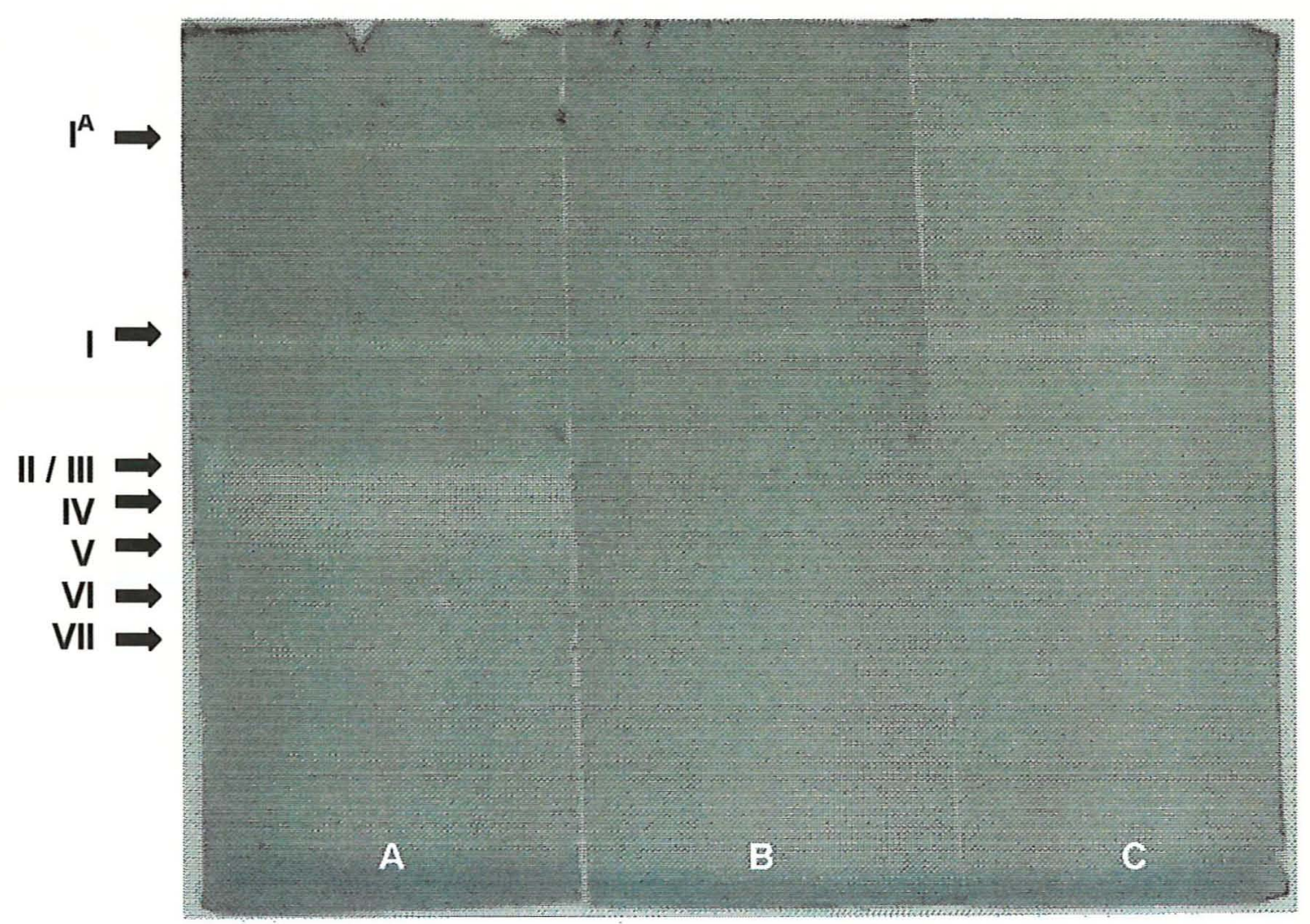

Figura 20: Caracterização das isoenzimas de SOD presentes em raizes de soja em PAGE não-desnaturante. $\operatorname{Em}(\mathrm{A})$ controle padrão de atividade, $(\mathrm{B})$ controle $+\mathrm{H}_{2} \mathrm{O}_{2}$ e (C) controle $+\mathrm{KCN}$.

\subsection{Atividade da GR}

A atividade de GR foi determinada em folhas e raízes de soja nos diferentes tratamentos.

No caso das folhas (Fig. 21) não foram observadas variações nas atividades de GR entre os tratamentos e os controles avaliados ao longo do tempo de exposição ao $\mathrm{CdCl}_{2}$. 


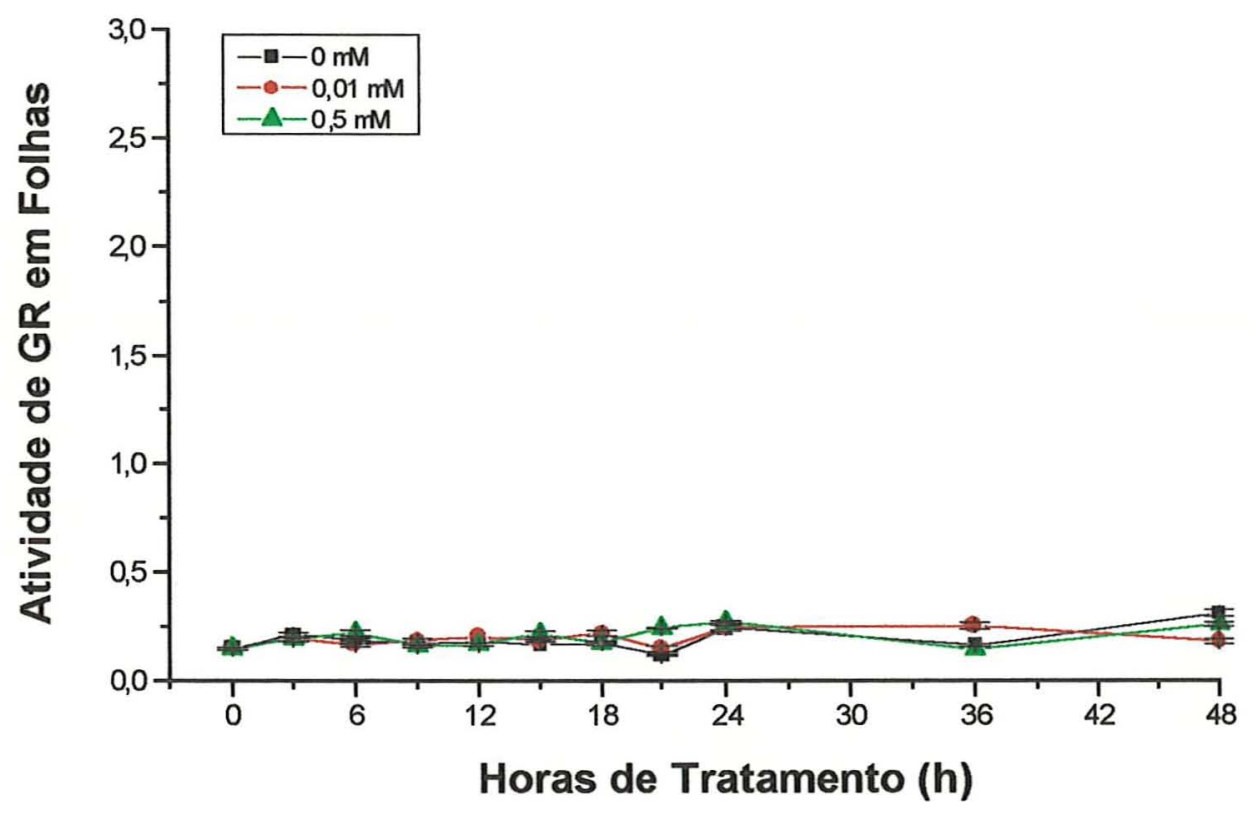

Figura 21: Atividade específica de GR ( $\mu \mathrm{mol} / \mathrm{min} / \mathrm{mg}$ prot) em folhas de plântulas de soja submetidas à diferentes concentrações de $\mathrm{CdCl}_{2}$.

No caso de raízes (Fig. 22), a atividade da GR apresentou um aumento significativo e expressivo nas plantas de soja submetidas à 0,5 mM de concentração de $\mathrm{CdCl}_{2}$ após $12 \mathrm{~h}$ de tratamento, em relação às plantas controles e ao tratamento com $0,01 \mathrm{mM} \mathrm{CdCl}_{2}$. Além do mais, o nível de atividade em raízes é cerca de cinco vezes mais alto do que o observado em folhas, baseado no controle geral $\left(0 \mathrm{~h}-0 \mathrm{mM}\right.$ de $\left.\mathrm{CdCl}_{2}\right)$. 


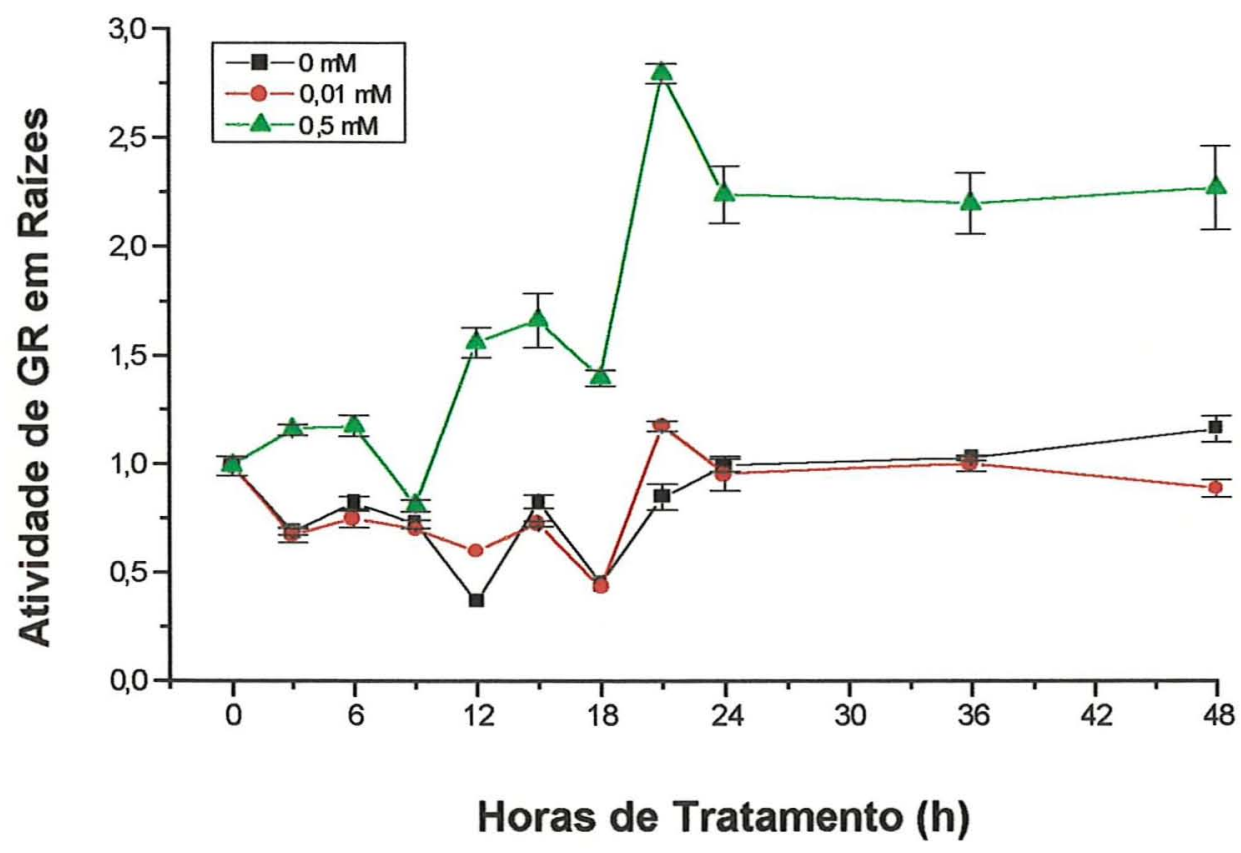

Figura 22: Atividade específica de GR ( $\mu \mathrm{mol} / \mathrm{min} / \mathrm{mg}$ prot) em raízes de plântulas de soja submetidas à diferentes concentrações de $\mathrm{CdCl}_{2}$. 


\section{DISCUSSÃO}

A toxicidade do $\mathrm{Cd}$ e outros metais pesados tem sido relatada em organismos vivos. $\mathrm{A}$ absorção de $\mathrm{Cd}$ pelas células vivas tem mostrado induzir efeitos drásticos, normalmente levando à morte celular dependendo da dose e tempo de exposição ao metal (Vitória et al., 2000).

Nas plantas, as concentrações tóxicas de $\mathrm{Cd}$ promovem várias alterações fisiológicas, principalmente induzidas pelas reações oxidativas desencadeadas pela geração das ROS (Prasad, 1995).

A diminuição no crescimento da parte aérea (Fig. 10 e 11) e da raiz (Fig. 9, 10 e 12) observada em plantas de soja submetidas a estresse por $\mathrm{Cd}$, mesmo na menor concentração $\left(0,5 \mathrm{mM} \mathrm{CdCl}_{2}\right)$, é uma caracteristica típica de plantas intoxicadas por esse metal pesado (Lamoreaux \& Chaney, 1977). Tal efeito tem sido observado em várias espécies de plantas, tais como, faia (Breckle \& Kahle, 1992), Holcus-lanatus L, Mimulus-guttatus, Silene-cucubalus (Ernst et al., 1992), arroz (Moya et al., 1993), ervilha (Leita et al., 1993), feijão (Rossi et al., 1998), cevada (Boussama et al., 1999) e rabanete (Vitória et al., 2000).

Além da inibição do crescimento, também foi observada senescência acelerada e clorose nas folhas de soja (Fig. 10), estando de acordo com os relatos de Nascimento \& Pereira (1997) para feijão e Das et al. (1997) para plantas superiores em geral, como o milho.

Foi observado também, o aparecimento de uma coloração marrom avermelhada nas margens e nervuras foliares das plântulas de soja, efeito este observado anteriormente por Schickler \& Caspi (1999), trabalhando com 
Alyssum argenteum e Alyssum maritimum. De acordo com Siedlecka \& Krupa (1999), esta coloração caracteriza-se pelo fato do Cd competir com o $\mathrm{Fe}$ por sitios de absorção na membrana plasmática, suprimindo a absorção e induzindo uma deficiência de Fe neste órgão.

Ao longo da evolução, as plantas desenvolveram vários mecanismos de defesa eficazes para proteção de suas células contra os danos oxidativos provocados pelas ROS, como por exemplo à síntese de PCs (Prasad \& Rengel, 1998) e enzimas antioxidantes, como a CAT, SOD e GR (Scandalios, 1993).

Embora não tenha sido quantificado a concentração de Cd que entrou no sistema vegetal nos tratamentos utilizados, tem-se observado que as plantas superiores, de uma maneira geral, acumulam o $\mathrm{Cd}$ preferencialmente no sistema radicular, cerca de $60 \%$ da concentração total deste metal absorvido, enquanto que o restante é transportado para outros tecidos, como folhas, sementes e caule (Siedlecka \& Krupa, 1999 e Vitória et al., 2000). Além do mais, as raizes são os principais sitios de sintese de PCs (MacMahon \& Anderson, 1998; Heiss et al., 1999 e Lee \& Leustek, 1999).

Inúmeros estudos têm sido realizados para avaliar o efeito do $\mathrm{Cd}$ nas atividades de CAT, SOD e GR em plantas superiores. A principal função da CAT é metabolizar os $\mathrm{H}_{2} \mathrm{O}_{2}$ liberados nos peroxissomos, produzidos na conversão do glicolato à glioxilato durante a fotorrespiração (Pimentel, 1998) e no metabolismo de ácidos graxos, particularmente na germinação das sementes (Holtman et al., 1993). Formas isoenzimáticas de CAT têm sido muito estudadas em plantas superiores, onde são freqüentemente codificados por três genes. Em Nicotiana plumbaginofolia, a transcrição de dois à três genes foi estimulada por $\mathrm{O}_{3}$ (Willekens et al., 1995), enquanto que a transcrição dos três genes de milho foi aumentada pela adição de $\mathrm{H}_{2} \mathrm{O}_{2}$ (Polidoros \& Scandalios, 1999). Por outro lado, a atividade da CAT foi grandemente reduzida quando plantas como cevada (Azevedo et al., 1998), faia (Polle et al., 1997) e soja (Booker et al., 1997) foram crescidas em altas concentrações de $\mathrm{CO}_{2}$, sugerindo que o $\mathrm{CO}_{2}$ desempenha um importante papel 
na diminuição do estresse oxidativo em plantas (Azevedo et al., 1998), além de intensificar o processo de fotossíntese e inibir a fotorrespiração, podendo o $\mathrm{CO}_{2}$, ser um verdadeiro promotor de produtividade agrícola (Booker et al., 1997).

No caso da soja, a atividade da CAT em folhas apresentou uma pequena diminuição após $36 \mathrm{~h}$ sob concentrações de 0,01 e $0,5 \mathrm{mM} \mathrm{CdCl}$ (Fig. 13), sugerindo que o $\mathrm{Cd}$ após este periodo interferiu no processo de fotossíntese (Barceló et al., 1988; Prasad, 1995; Prasad, M.N.V. 1997 e Siedlecka \& Krupa, 1999) nas plântulas de soja, promovendo alterações no mecanismo fotossintético, juntamente com a diminuição do processo de fotorrespiração e consequente diminuição na concentração de $\mathrm{H}_{2} \mathrm{O}_{2}$ nos peroxissomos, levando a uma diminuição na atividade de CAT nas folhas, enquanto em raízes, a CAT apresentou um nivel elevado constante de atividade na concentração de $0,5 \mathrm{mM} \mathrm{CdCl}_{2}$ (Fig. 14). Apesar das diferenças apresentadas em ambos os tecidos, as variações na atividade ao longo do tempo sugerem um padrão similar com mínima variação na atividade de CAT (Fig. 15 e 16). Diferentemente, em folhas de plantas de cevada (Patra \& Panda, 1998) e rabanete (Vitória et al., 2000) foi observado um aumento na atividade de CAT em resposta ao estresse causado pelo $\mathrm{Cd}$, sugerindo uma grande formação de ROS induzidas pela luz, neste órgão.

Os resultados para atividade de CAT em géis não desnaturantes, confirmaram os resultados obtidos no ensaio em espectrofotômetro. Além disto, não foram observadas isoenzimas de CAT nos tecidos analisados de plantas de soja, enquanto que em plantas de milho, são encontradas três isoformas de CAT (McMillin, 1983; Havir \& McHale, 1989 e Auh \& Scandalios, 1997), reguladas diretamente por um processo de sinalização iniciado pela concentração de $\mathrm{H}_{2} \mathrm{O}_{2}$ no tecido (Polidoros \& Scandalios, 1998 e 1999). Similarmente, algas verdes da espécie Chlamydomonas reinhardtii, também apresentaram três isoformas de CAT, expressas de acordo com o estágio de crescimento (Kato et al., 1997), sendo que no estágio de embriogênese 
zigótica, plantas de Aesculus hippocastanum apresentaram somente duas isoformas de CAT (Bagnoli et al., 1998). Diferentemente, plantas de ervilha apresentaram cinco isoformas de CAT nos peroxissomos foliares (Corpas et al., 1999), enquanto que em plantas de girassol, observou-se três isoformas de CAT em suas folhas (Palomo et al., 1999) e em cevada, apenas duas isoformas desta enzima (Skadsen et al., 1995).

No caso de folhas, foram detectadas bandas verde-escuras (X; Fig. $15)$, independente de serem do controle ou tratamento, indicando não estarem relacionadas ao estresse por $\mathrm{Cd}$. Estas bandas foram identificadas como sendo um complexo de proteínas do sistema antena coletor de luz associado ao fotossistema II (LHC II / PS II) (P. Lea, comunicação pessoal).

As SODs são as enzimas responsáveis pela conversão do $\mathrm{O}_{2}{ }^{\circ}-\mathrm{em}$ $\mathrm{H}_{2} \mathrm{O}_{2}$ e $\mathrm{O}_{2}$ (Scandalios, 1993), determinando as concentrações de $\mathrm{O}_{2}^{\circ}-\mathrm{e} \mathrm{H}_{2} \mathrm{O}_{2}$, os dois substratos da reação de Haber-Weiss que origina os radicais $\mathrm{OH}^{*}$ e provavelmente por isso, as SODs representam o mecanismo de defesa central dos organismos vivos (Bowler et al., 1992 e Alscher et al., 1998).

Três classes distintas de SODs têm sido detectadas em plantas, classificadas de acordo com o cofator metálico de seu sítio ativo, $\mathrm{Cu} / \mathrm{Zn}, \mathrm{Mn}$ ou Fe (Pan \& Yau, 1991; Bowler et al., 1992; Scandalios, 1993; Mattson, 1998 e Niyogi, 1999). As Cu/Zn-SOD são encontradas no citosol e cloroplastos de células eucariontes (Hayakawa et al., 1984), enquanto que as Mn-SODs tem sido encontradas em células procariontes, nas mitocôndrias de células eucariontes, embora uma Mn-SOD foi observada nos cloroplastos de algumas plantas (Sehmer \& Dizengremel, 1998) e as Fe-SODs são encontradas em células procariontes e nos cloroplastos, peroxissomos e mitocôndrias de células de algumas plantas (Becana et al., 1998).

Uma grande variedade de estresses oxidativos tem mostrado alterar o padrão de atividade de SOD assim como a expressão dos genes que codificam suas diferentes isoenzimas (Willekens et al., 1995). Esta alteração no padrão de atividade de SOD é bastante variada e muitas vezes dependente da espécie 
de planta, tecido, isoenzimas e etapas de desenvolvimento da espécie (Azevedo et al., 1998).

Por exemplo, a atividade da SOD foi diminuida drasticamente em folhas de plantas de milho sob alagamento (Yan et al., 1996) e aumentada em folhas de plantas de ervilha sob a ação do herbicida paraquat (Donahue et al. 1997), em plantas de feijão não aclimatadas submetidas à altas temperaturas (Edreva et al., 1998) e em Arabidopsis thaliana submetidas à radiação UV-B, principalmente pelo aumento da isoforma Cu/Zn-SOD (Rao et al., 1996). Enquanto que $\mathrm{O}_{3}$ induziu a formação de mRNA que traduz Cu/Zn-SOD citoplasmáticos, diminuiu a Fe-SOD e Cu/Zn-SOD dos cloroplastos e não teve nenhum efeito na tradução de mRNA de Mn-SOD nas mitocôndrias em plantas de Nicotiana plumbaginifolia. Os altos niveis de SOD, também estão envolvidos com maior tolerância ao armazenamento de vários frutos, como no caso de frutos de maçã e melão, onde a alta atividade da SOD evita a senescência acelerada dos frutos armazenados (Masia, 1998 e Lacan \& Baccou, 1998).

Neste trabalho, observou-se em plantas de soja que não ocorreram diferenças significativas entre os niveis de atividade de SOD, entre os tratamentos com $\mathrm{CdCl}_{2}$ e os controles em ambos os tecidos testados, sendo que nas folhas foram encontradas 7 isoformas de SOD (I, II, III, IV, V, VI e VII) e nas raízes, 8 isoformas de SOD ( $I^{A}, I, I I, I I, I V, V, V I$ e VII). Além disto, não foram observados variações específicas para qualquer das isoenzimas identificadas, seja nos controles como nos tratamentos, sugerindo que o estresse causado por $\mathrm{Cd}$ no desenvolvimento de soja, dentro das condições e concentrações utilizadas neste estudo, não induziu qualquer resposta ao nivel de atividade de SOD, sugerindo que não ocorreu aumento das ROS induzida pelo Cd. Resultados similares foram observados em cevada (Patra \& Panda, 1998). Entretanto, comparando ambos os tecidos analisados, a atividade de SOD nas raízes foi maior do que nas folhas, devido à diferença na concentração de proteinas utilizadas como amostras nos géis de ambos os tecidos, onde a concentração de proteínas foliares foi 3 vezes maior que a 
concentração protéica das raízes. Nas folhas foram observadas uma isoforma de Mn-SOD (I) e seis isoformas de Cu/Zn-SOD (II, III, IV, V, VI e VII) (Fig. 19) e nas raízes, foram encontradas duas isoformas de $M n-S O D\left(I^{A}\right.$ e $\left.I\right)$ e seis de Cu/Zn-SOD (II, III, IV, V, VI e VII) (Fig. 20). A isoforma III de ambos os tecidos e $a$ isoforma ${ }^{A}$ do tecido radicular são menos evidentes, devido à concentração de proteinas utilizadas como amostras, porém características em todos os tratamentos e controles.

A GR é uma enzima que contém um grupo prostético FAD transferidor de elétrons, responsável por catalisar a redução dependente de NADPH da glutationa oxidada (GSSG) para glutationa reduzida (GSH) (Creissen et al., 1994 e Voet \& Voet, 1995). A GSH é um importante metabólito no combate as ROS $\left(\mathrm{O}_{2}{ }^{\circ}-\mathrm{e} \mathrm{H}_{2} \mathrm{O}_{2}\right)$, sendo sua concentração muito alta nos cloroplastos, por participar da reciclagem do AsA por meio das atividades das enzimas do ciclo Halliwell-Asada, onde a enzima chave é a GR. A GSH está também envolvida na síntese de PCs para desintoxicação de íons metálicos (Lea et al., 1998). Em resposta à exposição a estresses ambientais tem sido relatado aumento na atividade de GR em algumas espécies de plantas (Lea et al., 1998), sendo encontradas isoformas nos cloroplastos, citosol e mitocôndrias (Donahue et al., 1997).

Inúmeros estudos relataram variações nas atividades de $G R$ em plantas sob condições de estresse. Os níveis de atividade de $\mathrm{Gr}$ em folhas de milho aumentaram em plantas submetidas à condição de seca (Del Longo et al., 1993), em culturas de células de soja sob ação de herbicidas (Knörzer et al., 1996), em plântulas de milho submetidas a baixas temperaturas (Prasad, T.K. 1997) e em plantas de cevada submetidas à exposição ao $\mathrm{O}_{3}$ (Azevedo et al., 1998). Por outro lado, a GR não apresentou alterações significativas em relação a outros tipos de estresse, como a ação do herbicida paraquat em pétalas de flores de crisântemo (Bartoli et al., 1997), estresse salino em plântulas de arroz cultivadas in vitro (Fadzilla et al., 1997), alagamento em 
plantas de milho (Yan et al., 1996). A atividade da GR também apresentou diminuição em plantas de café e culturas de parte aérea de arroz, submetidas à baixas temperaturas (Fadzilla et al., 1996 e Queiroz et al., 1998), em sementes de girassol em processo de senescência (Bailly et al., 1998), etc.

$A$ atividade de GR em folhas de plantas de soja, similarmente às atividades de CAT e SOD para ambos os tecidos analisados, não apresentou variações entre os tratamentos e os controles avaliados ao longo do tempo de exposição ao $\mathrm{CdCl}_{2}$ (Fig. 21). Entretanto em raízes, foi observado um aumento expressivo nas plantas submetidas à $0,5 \mathrm{mM} \mathrm{CdCl}_{2}$ após $12 \mathrm{~h}$ de tratamento, em relação às plantas controles e ao tratamento de $0,1 \mathrm{mM} \mathrm{C \textrm {Cl } _ { 2 }}$, durante o tempo de exposição (Fig. 22).

Este grande aumento da atividade de GR em raízes de plantas de soja, poderia ser explicado por duas formas distintas: (1) O ciclo HalliwellAsada é o principal mecanismo que opera na desintoxicação das ROS geradas pelo $\mathrm{Cd}$ nas raízes, produzindo altas concentrações de glutationa (GSH) e ascorbato (AsA), que fazem parte do sistema antioxidante não enzimático da planta, ou (2) a GR é essencial para manter a glutationa na sua forma reduzida (GSH), necessária para síntese de fitoquelatinas (PCs), responsáveis pela remoção do $\mathrm{Cd}$ e desintoxicação da planta, conforme sugerido também para plantas de rabanete (Vitória et al., 2000).

Hipoteticamente, se tivéssemos quantificado o acúmulo de $\mathrm{Cd}$ na raiz das plantas de soja e realizado análises em PAGE não desnaturante e SDSPAGE de proteína total dos tecidos estudados, poderiamos certamente chegar à constatar que o aumento da GR no tecido radicular estaria intrinsecamente ligado à síntese de PCs para remoção do $\mathrm{Cd}$ neste órgão. As presentes evidências poderiam sugerir que o ciclo Halliwell-Asada representa um papel principal na desintoxicação das ROS produzidas pelo $\mathrm{Cd}$ nas raizes ou ainda, que este ciclo desempenha papel fundamental na sintese de PCs, responsáveis pela remoção do $\mathrm{Cd}$ das raizes, impedindo a intoxicação das plantas de soja e consequentemente impedindo a produção das ROS. 


\section{CONCLUSÕES}

1- Foi observada a inibição do crescimento da parte aérea e raiz em plantas de soja submetidas à concentração de $0,5 \mathrm{mM} \mathrm{CdCl}_{2}$;

2- Não ocorreu variação significativa de atividade total de CAT ou de isoenzimas específicas em resposta ao estresse por $\mathrm{Cd}$, tanto em raiz como em folha de soja;

3- Foram observadas sete isoformas de SOD em folhas de soja, sendo uma Mn-SOD e as outras seis, Cu/Zn-SOD;

4- Foram observadas oito isoformas de SOD em raizes de soja, sendo duas Mn-SOD e seis, Cu/Zn-SOD;

5- Não ocorreu variação significativa de atividade total de SOD ou de isoenzimas específicas em resposta ao estresse por $\mathrm{Cd}$, tanto em raiz como em folha de soja;

6- Não ocorreu variação significativa de atividade total de GR em resposta ao estresse por $\mathrm{Cd}$, em folha de soja;

7- Foi observado um aumento de atividade total de GR em raiz de plantas de soja submetidas à concentração de $0,5 \mathrm{mM} \mathrm{CdCl}_{2}$. 


\section{REFERÊNCIAS BIBLIOGRÁFICAS}

ACEVEDO, A.; SCANDALIOS, J.G. Antioxidant gene (Cat/Sod) expression during the process of accelerated senescence in silks of the maize ear shoot. Plant Physiology Biochemistry, v.34, n.4, p.539-545, 1996.

ALSCHER, R.G. Biosynthesis and antioxidant function of glutathione in plants. Physiologia Plantarum, v.77, p.457-464, 1989.

ALSCHER, R.G.; DONAHUE, J.L.; CRAMER, C.L. Molecular responses to reactive oxygen species: multifaceted changes in gene expression. In: $\mathrm{DE}$ KOK, L.J.; STULEN, I. (Ed.) Responses of plant metabolism to air pollution and global change. Leiden, The Netherlands: Backhuys Publishers, 1998. p.233-240.

ANDERSON, M.D.; PRASAD, T.K.; STEWART, C.R. Changes in isozyme profiles of catalase, peroxidase, and glutathione reductase during acclimation to chilling in mesocotyls of maize seedlings. Plant Physiology, v.109, p.1247-1257, 1995.

ANDREWS, C.J. How do plants survive ice? Annuals of Botany, v.78, p.529$536,1996$. 
AONO, M.; ANDO, M.; NAKAJIMA, N.; KUBO, A.; KONDO, N.; TANAKA, K.; SAJI, $H$. Response to photooxidative stress of transgenic tobacco plants with altered activities of antioxidant enzymes. In: DE KOK, L.J.; STULEN, I. (Ed.) Responses of plant metabolism to air pollution and global change. Leiden, The Netherlands: Backhuys Publishers, 1998. p.269-272.

ASADA, K. The water-water cycle in chloroplasts: scavenging of active oxygens and dissipation of excess photons. Annual Review of Plant Physiology and Plant Molecular Biology, v.50, p.601-639, 1999.

AUH, C.; SCANDALIOS, J.G. Spatial and temporal responses of the maize catalases to low temperature. Physiologia Plantarum, v.101, p.149-156, 1997.

AZEVEDO, R.A.; ALAS, R.M.; SMITH, R.J.; LEA, P.J. Response of antioxidant enzymes to transfer from elevated carbon dioxide to air and ozone fumigation, in leaves and roots of wild-type and a catalase-deficient mutant of barley. Physiologia Plantarum , v.104, p.280-292, 1998.

BACCOUCH, S.; CHAOUI, A.; EL FERJANI, E. Nicked-induced oxidative damage and antioxidant responses in Zea mays shoots. Plant Physiology Biochemistry, v.36, n.9, p.689-694, 1998.

BAGNOLI, F.; CAPYUANA, M.; RACCHI, M.L. Developmental changes of catalase and superoxide dismutase isoenzymes in zygotic and somatic embryos of horse chestnut. Australian Journal of Plant Physiology, v.25, n.8, p.909-913, 1998. 
BAILLY, C.; BENAMAR, A.; CORBINEAU, F.; CÔME, D. Free radical scavenging as affected by accelerated ageing and subsequent priming in sunflower seeds. Physiologia Plantarum, v.104, p.646-652, 1998.

BARATA, R.M. Caracterização fisiológica e molecular de plantas transgênicas de tabaco expressando a leghemoglobina de soja no interior dos cloroplastos. Piracicaba, 1999. 116p. Dissertação (M.S.) - Escola Superior de Agricultura "Luiz de Queiroz", Universidade de São Paulo.

BARCELÓ, J.; VASQUES, M.D.; POSCHENRIEDER, C. Structural and ultrastructural disorders in cadmium-treated bush bean plants (Phaseolus vulgaris L.). New Phytologist, v.108, n.1, p.37-49, 1988.

BARTOLI, C.G.; SIMONTACCHI, M.; MONTALDI, E.R.; PUNTARULO, S. Oxidants and antioxidants during aging of chrysanthemum petals. Plant Science, v.129, n.2, p.157-265, 1997.

BECANA, M.; MORAN, J.F.; ITURBE-ORMAETXE, I. Iron-dependent oxygen free radical generation in plants subjected to environmental stress: toxicity and antioxidant protection. Plant and Soil, v.201, p.137-147, 1998.

BENTIVENGA, G.; BONINI, C.; D'AURIA, M.; DE BONA, A.; MAURIELLO, G. Singlet oxygen mediated degradation of klason lignin. Chemosphere, v.39, n.14, p.2409-2417, 1999.

BHATTACHARJEE, S. Membrane lipid peroxidation, free radical scavengers and ethylene evolution in Amaranthus as affected by lead and cadmium. Biologia Plantarum, v.40, n.1, p.131-135, $1997 / 98$. 
BILODEAU, C.; CHEVRIER, N. Endogenous ascorbate level modulates ozone tolerance in Euglena gracilis cells. Plant Physiology Biochemistry, v.36, n.9, p.695-702, 1998.

BOOKER, F.L.; REID, C.D.; BRUNSCHÖN-HARTI, S.; FISCUS, E.L.; MILLER, J.E. Photosynthesis and photorespiration in soybean [Glycine max (L.) Merr.] chronically exposed to elevated carbon dioxide and ozone. Journal of Experimental Botany, v.48, n.315, p.1843-1852, 1997.

BOUSSAMA, N.; OUARITI, O.; GHORBAL, M.H. Changes in growth and nitrogen assimilation in barley seedlings under cadmium stress. Journal of Plant Nutrition, v.22, n.4 e 5, p.731-752, 1999.

BOUSSAMA, N.; OUARITI, O.; SUZUKI, A.; GHORBAL, M.H. Cd-stress on nitrogen assimilation. Journal of Plant Physiology, v.155, p.310-317, 1999.

BOWLER, C.; VAN MONTAGU, M.; INZÉ, D. Superoxide-dismutase and stress tolerance. Annual Review of Plant Physiology and Plant Molecular Biology, v.43, p.83-116, 1992.

BRADFORD, M.M. A rapid and sensitive method for the quantitation of microgram quantities of protein utilizing the principle of protein-dye binding. Analytical Biochemistry, v.72, p.248-259, 1976.

BRECKLE, S.W.; KAHLE, $H$. Effects of toxic heavy-metals $(\mathrm{Cd}, \mathrm{Pb})$ on growth and mineral-nutrition of beech (Fagus-sylvatica L). Vegetatio, v.101, n.1, p.43-53, 1992. 
CAKMAK, I.; MARSCHNER, $H$. Magnesium deficiency and high light intensity enhance activities of superoxide dismutase, ascorbate peroxidase, and glutathione reductase in bean leaves. Plant Physiology, v.98, p.1222-1227, 1992.

CARRÃO-PANIZZI, M.C. Potential uses of soybean as food in South America. JIRCAS Working Report, n.13, p.89-96, 1998.

CARRÃO-PANIZZI, M.C.; KITAMURA, K. Isoflavone content in Brazilian soybean cultivars. Breeding Science, v.45, p.295-300, 1995.

CARRÃO-PANIZZI, M.C.; KITAMURA, K.; BELÉIA, A.D.P.; OLIVEIRA, M.C.N. Influence of growth locations on isoflavone contents in Brazilian soybean cultivars. Breeding Science, v.48, p.409-413, 1998.

CHAOUI, A.; GHORBAL, M.H.; EL FERJANI, E. Effects of cadmium-zinc interactions on hydroponically grown bean (Phaseolus vulgaris L.). Plant Science, v.126, p.21-28, 1997a.

CHAOUI, A.; MAZHOUDI, S.; GHORBAL, M.H.; EL FERJANI, E. Cadmium and zinc induction of lipid peroxidation and effects on antioxidant enzyme activities in bean. Plant Science, v.127, p.139-147, 1997b.

CHEN, S.L.; KAO, C.H. Glutathione reduces the inhibition of rice seedlings root growth caused by cadmium. Plant Growth Regulation, v.16, p.249-252, 1995. 
CORPAS, F.J.; PALMA, J.M.; SANDALIO, L.M.; LOPEZ-HUERTAS, E.; ROMERO-PUERTAS, M.C.; BARROSO, J.B.; DEL RIO, L.A. Purification of catalase from pea leaf peroxisomes: identification of five different isoforms. Free Radical Research, v.31 (Suppl.), p.235-241, 1999.

CREISSEN, G.P.; EDWARDS, E.A.; MULLINEAUX, P.M. Glutathione reductase and ascorbate peroxidase. In: FOYER, C.H.; MULLINEAUX, P.M. (Ed.) Causes of photoxidative stress and amelioration of defence systems in plants. CRC Press: Boca Raton, Florida, 1994. p.343-364.

DAI, Q.; YAN, B.; HUANG, S.; LIU, X.; PENG, S.; MIRANDA, M.L.L.; CHAVEZ, A.Q.; VERGARA, B.S.; OLSZYK, D.M. Response of oxidative stress defence systems in rice (Oryza sativa) leaves with supplemental UV-B radiation. Physiologia Plantarum, v.101, p.301-308, 1997.

DAS, P.; SAMANTARAY, S.; ROUT, G.R. Studies on cadmium toxicity in plants: a review. Environmental Pollution, v.98, n.1, p.29-36, 1997.

DEL LONGO, O.T.; GONZÁLEZ, C.A.; PASTORI, G.M.; TRIPPI, V.S. Antioxidant defences under hyperoxygenic and hyperosmotic conditions in leaves of two lines of maize with differential sensitivity to drought. Plant Cell Physiology, v.34, n.7, p.1023-1028, 1993.

DONAHUE, J. L.; OKPODU, C.M.; CRAMER, C.L.; GRABAU, E.A.; ALSCHER, R.G. Responses of antioxidants to paraquat in pea leaves. Plant Physiology, v.113, p.249-257, 1997.

DOULIS, A.G.; DEBIAN, N.; KINGSTON-SMITH, A.H.; FOYER, C.H. Differential localization of antioxidants in maize leaves. Plant Physiology, v.114, p.1031-1037, 1997. 
DU, H.; KLESSIG, D.F. Identification of a soluble, high-affinity salicylic acidbinding protein in tobacco. Plant Physiology, v.113, p.1319-1327, 1997.

EDREVA, A.; YORDANOV, I.; KARDJIEVA, R.; GESHEVA, E. Heat shock responses of bean plants: involvement of free radicals, antioxidants and free radicals/active oxygen scavenging systems. Biologia Plantarum, v.41, n.2, p.185-191, 1998.

EL-SAHT, H.M. Responses to chilling stress in French bean seedlings: antioxidant compounds. Biologia Plantarum, v.41, n.3, p.395-402, 1998.

EMBRAPA SOJA (Londrina, PR). Recomendações técnicas para a cultura da soja na região central do Brasil 1999/2000. Londrina, 1999. 226p. (Embrapa Soja. Documentos, 132; Embrapa Agropecuária Oeste, 5).

ERDEI, L.; SZEGLETES, Z.; BARABÁS, K.N.; PESTENÁCS, A.; FÜLÖP, K.; KALMÁR, L.; KOVÁCS, A.; TÓTH, B.; DÉR, A. Environmental stress and the biological clock in plants: changes of rhythmic behavior of carbohydrates, antioxidant enzymes and stomatal resistance by salinity. Journal of Plant Physiology, v.152, p.265-271, 1998.

ERNST, W.H.O.; VERKLEIJ, J.A.C.; SCHAT, H. Metal tolerance in plants. Acta Botanica Neerlandica, v.41, n.3, p.229-248, 1992.

FADZILLA, N.M.; FINCH, R.P.; BURDON, R.H. Salinity, oxidative stress and antioxidant responses in shoot cultures of rice. Journal of Experimental Botany, v.48, n.307, p.325-331, 1997. 
FADZILLA, N.M.; GILL, V.; FINCH, R.P.; BURDON, R.H. Chilling, oxidative stress and antioxidant responses in shoot cultures of rice. Planta, v.199, p.552-556, 1996.

FERNANDES, F.M.; ATHAYDE, M.L.F.; LARA, F.M. Comportamento de cultivares de soja no campo em relação ao ataque de percevejos. Pesquisa Agropecuária Brasileira, v.29, n.3, p.363-367, mar., 1994.

FLORIJN, P.J.;DEKNECHT, J.A.; VANBEUSICHEM, M.L. Phytochelatin concentrations and binding state of $c d$ in roots of maize genotypes differing in shoot root cd partitionimng. Journal of Plant Physiology, v.142, n.5, p.537$542,1993$.

FOYER, C.H.; LELANDAIS, M.; KUNERT, K.J. Photooxidative stress in plants. Physiologia Plantarum, v.92, p.696-717, 1994.

FRUGOLI, J.A.; MCPEEK, M.A.; THOMAS, T.L.; McCLUNG, C.R. Intron loss and gain during evolution of the catalase gene family in angiosperms. Genetics, v.149, p.355-365, May, 1998.

FRUGOLI, J.A.; ZHONG, H.H.; NUCCIO, M.L.; McCOURT, P.; McPEEK, M.A.; THOMAS, T.L.; McCLUNG, C.R. Catalase is encoded by a multigene family in Arabidopsis thaliana (L.) Heynh. Plant Physiology, v.112, p.327-336, 1996.

GALLI, U.; SCHÜEPP, H.; BRUNOLD, C. Thiols in cadmium-and coppertreated maize (Zea mays L.). Planta, v.198, p.139-143, 1996. 
GAZZONI, D.L. Manejo de pragas da soja. In: VERNETTI, F.J. (Coord.) Soja: planta, clima, pragas, moléstias e invasoras. Campinas: Fundação Cargill, 1983. v.1. p.193-338.

GHOSHROY, S.; FREEDMAN, K.; LARTEY, R.; CITOVSKY, V. Inhibition of plant viral systemic infection by non-toxic concentrations of cadmium. The Plant Journal, v.13, n.5, p.591-602, 1998.

GIANNOPOLITIS, C.N.; RIES, S.K. Superoxide dismutases - I. occurrence in higher plants. Plant Physiology, v.59, p.309-314, 1977.

GIMENO-GARCIA, E.; ANDREU, V.; BOLUDA, R. Heavy metals incidence in the application of inorganic fertilizers and pesticides to rice farming soils. Environmental Pollution, v.92, n.1, p.19-25, 1996.

GRILL, E.; WINNACKER, E.L.; ZENK, M.H. Phytochelatins: the principal heavy-metal complexing peptides of higher plants. Science, v.230, n.4726, p.674-676, 1985.

GUPTA, Y.P. Nutritive value of food legumes. In: ARORA, S.K. (Ed.) Chemistry and biochemistry of legumes. London: Edward Arnold, 1983. p.287-328.

GUYTON, A.C. Tratado de Fisiologia Médica. 8.ed. Trad. de C.R. Ferreira Filho, C.A. Esbérard, F.D. Mundim e P.L.V. Pinho. Rio de Janeiro: Editora Guanabara Koogan S.A., 1992. 864p.

HAGEN, G.; UHRHAMMER, N.; GUIFOYLE, T.J. Regulation of expression of an auxin-induced soybean sequence by cadmium. The Journal of Biological Chemistry, v.263, n.13, p.6442-6446, May, 1988. 
HAVIR, E.A.; McHALE, N.A. Regulation of catalase activity in leaves of Nicotiana sylvestris by high $\mathrm{CO}_{2}$. Plant Physiology, v.89, p.952-957, 1989.

HAYAKAWA, T.; KANEMATSU, S.; ASADA, K. Occurrence of Cu,Znsuperoxide dismutase in the intrathylakoid space of spinach chloroplasts. Plant and Cell Physiology, v.25, n.6, p.883-889, 1984.

HEISS, S.; SCHÄFER, H.J.; HAAG-KERWER, A.; RAUSCH, T. Cloning sulfur assimilation genes of Brassica juncea $L .:$ cadmium differentially affects the expression of a putative low-affinity sulfate transporter and isoforms of ATP sulfurylase and APS reductase. Plant Molecular Biology, v.39, p.847-857, 1999.

HOAGLAND, D.R.; ARNON, D.I. The water culture method for growing plant without soil. Bekerley: University of California agricultural experiment station bulletin, 1951. 347p.

HOLTMAN, W.L.;VAN DUIJN, G.; ZIMMERMANN, D.; BAKHUIZEN, R.; DODERER, A.; DONKER, W.; HEISTEK, J.C.; SCHRAM, A.W.; VALK, B.E.; DOUMA, A.C. Monoclonal antibodies for differential recognition of catalase subunits in barley aleurone cells. Plant Physiology Biochemistry, v.31, n.3, p.311-321, 1993.

HOWDEN, R.; GOLDSBROUGH, P.B.; ANDERSEN, C.R.; COBBETT, C.S. Cadmium-sensitive, cad1 mutants of arabidopsis-thaliana are phytochelatin deficient. Plant Physiology, v.107, n.4, p.1059-1066, Apr., 1995.

IRETSKAYA, S.N.; CHIEN, S.H.; MENON, R.G. Effect of acidulation of high cadmium containing phosphate rocks on cadmium uptake by upland rice. Plant and Soil, v.201, p.183-188, 1998. 
IWAMOTO, M.; MAEKAWA, M.; SAITO, A. Evolutionary relationship of plant catalase genes inferred from exon-intron structures: isozyme divergence after the separation of monocots and dicots. Theoretical and Applied Genetics, v.97, p.9-19, 1998.

JARVIS, S.C.; JONES, L.H.P.; HOPPER, M.J. Cadmium uptake from solution by plants and its transport from roots to shoots. Plant and Soil, v.44, p.179$191,1976$.

JEMAL, F.; DIDIERJEAN, L.; GHRIR, R.; GHORBAL, M.H.; BURKARD, G. Characterization of cadmium binding peptides from pepper (Capsicum annuum). Plant Science, v.137, p.143-154, 1998.

JIMÉNEZ, A.; HERNÁNDEZ, J.A.; DEL RIO, L.A.; SEVILLA, F. Evidence for the presence of the ascorbate-glutathione cycle in mitochondria and peroxisomes of pea leaves. Plant Physiology, v.114, p.1-10, 1997.

JU, G.C.; LI, X.; RAUSER, W.E.; OAKS, A. Influence of cadmium on the production of $\gamma$-glutamylcysteine peptides and enzymes of nitrogen assimilation in Zea mays seedlings. Physiologia Plantarum, v.101, p.793$799,1997$.

KATO, J.; YAMAHARA, T.; TANAKA, K.; TAKIO, S.; SATOH, T. Characterization of catalase from green algae Chlamydomonas reinhardtii. Journal of Plant Physiology, v.151, p.262-268, 1997.

KIANG, Y.T.; GORMAN, M.B. Soybean. In: TANKSLEY, S.D.; ORTON, T.J. (Ed.) Isozymes in plant genetics and breeding, part B. Amsterdam; Oxford; New York: Elsevier, 1983. p.295-328. 
KNÖRZER, O.C.; DURNER, J.; BÖGER, P. Alterations in the antioxidative system of suspension-cultured soybean cells (Glycine max) induced by oxidative stress. Physiologia Plantarum, v.97, p.388-396, 1996.

KUBOI, T.; NOGUCHI, A.; YAZAKI, J. Relationship between tolerance and accumulation characteristics of cadmium in higher plants. Plant and Soil, v.104, p.275-280, 1987.

LACAN, D.; BACCOU, J.C. High levels of antioxidant enzymes correlate with delayed senescence in nonnetted muskmelon fruits. Planta, v.204, p.377$382,1998$.

LAEMMLI, U.K. Cleavage of structural proteins during the assembly of the head of bacteriophage T4. Nature, v.227, p.680-685, 1970.

LAGRIFFOUL, A.; MOCQUOT, B.; VANGRONSVELD, J.; MENCH, M. Cadmium toxicity effects on growth, mineral and chlorophyll contents, and activities of stress related enzymes in young maize plants (Zea mays L.). Plant and Soil, v.200, p.241-250, 1998.

LAMOREAUX, R.J.; CHANEY, W.R. Growth and water-movement in silver maple seedlings affected by cadmium. Journal of Environmental Quality, v.6, n.2, p.201-205, 1977.

LEA, P.J.; WELLBURN, F.A.M.; WELLBURN, A.R.; CREISSEN, G.P.; MULLINEAUX, P.M. Use of transgenic plants in the assessment of responses to atmospheric pollutants. In: DE KOK, L.J.; STULEN, I. (Ed.) Responses of plant metabolism to air pollution and global change. Leiden, The Netherlands: Backhuys Publishers, 1998. p.241-250. 
LEE, K.C.; CUNNINGHAN, B.A.; PAULSEN, G.M.; LIANG, G.H.; MOORE, R.B. Effects of cadmium on respiration rate and activities of several enzymes in soybean seedlings. Physiologia Plantarum, v.36, p.4-6, 1976.

LEE, S.M.; LEUSTEK, T. The effect of cadmium on sulfate assimilation enzymes in Brassica juncea. Plant Science, v.141, p.201-207, 1999.

LEITA, L.; CONTIN, M.; MAGGIONI, A. Distribution of cadmium and induced Cd-binding proteins in roots, stems and leaves of Phaseolus vulgaris. Plant Science, v.77, p.139-147, 1991.

LEITA, L.; DE NOBILI, M.; CESCO, S.; MONDINI, C. Analysis of intercellular cadmium forms in roots and leaves of bush bean. Journal of Plant Nutrition, v.19, n.3/4, p.527-533, 1996.

LEITA, L.; DE NOBILI, M.; MONDINE, C.; BACA GARCIA, M. T. Response of leguminosae to cadmium exposure. Journal of Plant Nutrition, v.16, n.10, p.2001-2012, 1993.

LEOPOLD, I.; GÜNTHER, D.; SCHMIDT, J.; NEUMANN, D. Phytochelatins and heavy metal tolerance. Phytochemistry, v.50, p.1323-1328, 1999.

LESHEM, Y.Y.; KUIPER, P.J.C.; ERDEI, L.; LURIE, S.; PERL-TREVES, R. Do Selye's mammalian "GAS" concept and "co-stress" response exist in plants? Annals New York Academy of Sciences, v.851, p.199-208, 1998.

LICHTENTHALER, H.K. Vegetation stress: an introduction to the stress concept in plants. Journal of Plant Physiology, v.148, p.4-14, 1996. 
LOZANO-RODRIGUEZ, E.; HERNÁNDEZ, L.E.; BONAY, P.; CARPENA-RUIZ, R.O. Distribution of cadmium in shoot and root tissues of maize and pea plants: physiological disturbances. Journal of Experimental Botany, v.48, n.306, p.123-128, 1997.

MACMAHON, P.J.; ANDERSON, J.W. Preferential allocation of sulphur into gamma glutamylcysteinyl peptides in wheat plants grown at low sulphur nutrition in the presence of cadmium. Physiologia Plantarum, v.104, p.440448, 1998.

MALAN, H.L.; FARRANT, J.M. Effects of the metal pollutants cadmium and nickel on soybean seed development. Seed Science Research, v.8, p.445453, 1998.

MALAVOLTA, E. Fertilizantes e seu impacto ambiental: micronutrientes e metais pesados, mitos, mistificação e fatos. São Paulo, Produquímica, 1994. 153p.

MALIK, S.S.; SINGH, B.B.; GARG, G.K. Isozymic variation in relation to yellow mosaic disease in soybean. Indian Journal of Genetics and Plant Breeding, v.56, n.4, p.462-467, 1996.

MARGARIDO, M.A.; SOUZA, E.L.L. Formação de preços da soja no Brasil. Agricultura em São Paulo, v.45, n.2, p.52-61, 1998.

MASIA, A. Superoxide dismutase and catalase activities in apple fruit during ripening and post-harvest and with special reference to ethylene. Physiologia Plantarum, v.104, p.668-672, 1998. 
MATTIAZZO-PREZOTTO, M.E. Comportamento de cobre, cádmio, crômio, níquel e zinco adicionados a solos de clima tropical em diferentes valores de pH. Piracicaba, 1994. 197p. Tese (Livre-Docência) - Escola Superior de Agricultura "Luiz de Queiroz", Universidade de São Paulo.

MATTSON, M.P. Answering the old age question. Chemistry \& Industry, v.20, p.843-848, 1998.

MAZHOUDI, S.; CHAOUI, A.; GHORBAL, M.H.; EL FERJANI, E. Response of antioxidant enzymes to excess copper in tomato (Lycopersicon esculentum, Mill.). Plant Science, v.127, p.129-137, 1997.

MCGRATH, S.P.; DUNHAM, S.J.; ATKIN, R.K. An extracting science. Chemistry \& Industry, v.22, p.915-918, 1998.

MCMILLIN, D.E. Plant isozymes: a historical perspective. In: TANKSLEY, S.D.; ORTON, T.J. (Ed.) Isozymes in plant genetics and breeding, part A. Amsterdam; Oxford; New York: Elsevier, 1983. p.3-15.

MELO, W.J.; MARQUES, M.O.; SILVA, F.C.; BOARETTO, A.E. Uso de Resíduos Sólidos Urbanos na Agricultura e Impactos Ambientais. IApresentado ao XXVI Congresso Brasileiro de Ciência do Solo, Rio de Janeiro, 20-26 de Julho de 1997. 28p.

MIYAKE, H.; MATSUMURA, H.; FUJINUMA, Y.; TOTSUKA, T. Effects of low concentrations of ozone on the fine structure of radish leaves. New Phytology, v.111, p.187-195, 1989. 
MOCQUOT, B.; VANGRONSVELD, J.; CLIJSTERS, H.; MENCH, M. Copper toxicity in young maize (Zea mays L.) plants: effects on growth, mineral and chlorophyll contents, and enzyme activities. Plant and Soil, v.182, p.287$300,1996$.

MOHAN, B.S.; HOSETTI, B.B. Potential phytotoxicity of lead and cadmium to Lemna minor grown in sewage stabilization ponds. Environmental Pollution, v.98, n.2, p.233-238, 1997.

MOYA, J.L.; ROS, R.; PICAZO, I. Influence of cadmium and nickel on growth, net photosynthesis and carbohydrate distribution in rice plants. Photosynthesis Research, v.36, n.2, p.75-80, 1993.

NASCIMENTO, C.W.A.; PEREIRA, J.B.M. Absorção e distribuição de cádmio e micronutrientes em cultivares de feijoeiro expostas a doses de cádmio. Pesquisa Agropecuária Brasileira, v.32, n.12, p.1303-1308, 1997.

NEUMANN, P. Salinity resistance and plant growth revisited. Plant Cell and Environment, v.20, p.1193-1198, 1997.

NEWTON, K.J. Genetics of mitochondrial isozymes. In: TANKSLEY, S.D.; ORTON, T.J. (Ed.) Isozymes in plant genetics and breeding, part A. Amsterdam; Oxford; New York: Elsevier, 1983. p.159-177.

NIYOGI, K.K. Photoprotection revisited: genetic and molecular approaches. Annual Review of Plant Physiology and Plant Molecular Biology, v.50, p.333-359, 1999. 
OLIVEIRA, J.A.; OLIVA, M.A.; CAMBRAIA, J. Effects of cadmium on chlorophyll contents and on peroxidase activity in soybean. Revista Brasileira de Fisiologia Vegetal, v.6, n.2, p.97-101, 1994b.

OLIVEIRA, J.A.; OLIVA, M.A.; CAMBRAIA, J.; VENEGAS, H.A. Absorption, accumulation and distribution of cadmium by two soybean cvs. Revista Brasileira de Fisiologia Vegetal, v.6, n.2, p.91-95, 1994a.

OLIVEIRA, J.E.D.; CUNHA, S.F.C.; MARCHINI, J.S. A desnutrição dos pobres e dos ricos - dados sobre alimentação no Brasil. Sarvier, São Paulo, p.123, 1996.

PALOMO, P.J.; LOPEZ-VALBUENA, R.; TENA, M. Sunflower (Helianthus annus) variability in antioxidant enzyme defenses. Free Radical Research, v.31 (Suppl.), p.227-233, 1999.

PAN, S.; YAU, Y. The isozymes of superoxide dismutase in rice. Botanical Bulletin of Academia Sinica, v.32, p.253-258, 1991.

PANAVAS, T.; RUBINSTEIN, B. Oxidative events during programmed cell death of daylily (Hemerocallis hybrid) petals. Plant Science, v.133, p.125138, 1998.

PANIZZI, A.R.; CARRÃO-PANIZZI, M.C.; BAYS, I.A.; ALMEIDA, L.A. Danos por percevejos em genótipos de soja com semente pequena. Pesquisa Agropecuária Brasileira, v.21, n.6, p.571-577, jun., 1986.

PATRA, J.; PANDA, B.B. A comparison of biochemical responses to oxidative and metal stress in seedlings of barley, Hordeum vulgare $L$. Environmental Pollution, v.101, p.99-105, 1998. 
PIMENTEL, C. Metabolismo de Carbono na Agricultura Tropical. Rio de Janeiro: EDUR, 1998. 159p.

PINHEIRO, J.B. Dialelo parcial entre parentais de soja resistentes e suscetíveis a insetos. Piracicaba, 1993. 143p. Dissertação (M.S.) - Escola Superior de Agricultura "Luiz de Queiroz", Universidade de São Paulo.

PINHERO, R.G.; RAO, M.V.; PALIYATH, G.; MURR, D.P.; FLETCHER, A. Changes in activities of antioxidant enzymes and their relationship to genetic and paclobutrazol-induced chilling tolerance of maize seedlings. Plant Physiology, v.114, p.695-704, 1997.

PIQUERAS, A.; HAN, B.H.; VAN HUYLENBROECK, J.M.; DEBERGH, P.C. Effect of different environmental conditions in vitro on sucrose metabolism and antioxidant enzymatic activities in cultured shoots of Nicotiana tabacum L. Plant Growth Regulation, v.25, p.5-10, 1998.

POLIDOROS, A.N.; SCANDALIOS, J.G. Circadian expression of the maize catalase Cat 3 gene is highly conserved among diverse maize genotypes with structurally different promoters. Genetics, v.149, p.405-415, May, 1998.

POLIDOROS, A.N.; SCANDALIOS, J.G. Role of hydrogen peroxide and different classes of antioxidants in the regulation of catalase and glutathione S-transferase gene expression in maize (Zea mays L.). Physiologia Plantarum, v.106, p.112-120, 1999.

POLLE, A.; EIBLMEIER, M.; SHEPPARD, L.; MURRAY, M. Responses of antioxidative enzymes to elevated $\mathrm{CO}_{2}$ in leaves of beech (Fagus sylvatica L.) seedlings grown under a range of nutrient regimes. Plant Cell and Environment, v.20, p.1317-1321, 1997. 
PRASAD, M.N.V. Cadmium toxicity and tolerance in vascular plants. Environmental and Experimental Botany, v.35, n.4, p.525-545, 1995.

PRASAD, M.N.V. Plant Ecophysiology. New York; Chichester; Brisbane; Toronto; Singapore; Weinheim: John Wiley \& Sons, Inc., 1997. 542p.

PRASAD, M.N.V.; RENGEL, Z. Plant acclimation and adaptation to natural and anthropogenic stress. Annals New York Academy of Sciences, v.851, p.216-223, 1998.

PRASAD, T.K. Role of catalase in inducing chilling tolerance in pre-emergent maize seedlings. Plant Physiology, v.114, p.1369-1376, 1997.

PRASAD, T.K.; ANDERSON, M.D.; STEWART; C.R. Localization and characterization of peroxidases in the mitochondria of chilling-acclimated maize seedlings. Plant Physiology, v.108, p.1597-1605, 1995.

PRZYMUSINSKI, R.; GWÓZDZ, A. Heavy metal-induced polypeptides in lupin roots are similar to pathogenesis-related proteins. Journal of Plant Physiology, v.154, p.703-708, 1999.

QUEIROZ, C.G.S.; ALONSO, A.; MARES-GUIA, M.; MAGALHÃES, A.C. Chilling-induced changes in membrane fluidity and antioxidant enzyme activities in Coffea arabica L. roots. Biologia Plantarum, v.41, n.3, p.403413, 1998.

RAO, M.V.; PALIYATH, G.; ORMROD, D.P. Ultraviolet-B and ozone-induced biochemical changes in antioxidant enzymes of Arabidopsis thaliana. Plant Physiology, v.110, p.125-136, 1996. 
REESE, R. N.; WHITE, C. A.; WINGE, D. R. Cadmium-sulfide crystallites in $\mathrm{Cd}-(\gamma \mathrm{EC})_{n} \mathrm{G}$ peptide complexes from tomato. Plant Physiology, v.98, p.225229, 1992.

RICE-EVANS, C.A.; DIPLOCK, A.T.; SYMONS, M.C.R. Techniques in free radical research. In: BURDON, R.H.; VAN KNIPPENBERG, P.H. (Ed.) Laboratory techniques in biochemistry and molecular biology. Amsterdam; London; New York; Tokio: Elsevier, 1991. v.22. 291p.

ROSS, S.M. (Ed.), Toxic metals in soil plant systems. Wiley, Chichester, UK, 469p. 1994.

ROSSETO, C.J. Breeding for resistance to stink bugs. In: WORLD SOYBEAN RESEARCH CONFERENCE, IV. Proceedings. Argentina: Buenos Aires, 1989. p.2046-2060.

ROSSETO, C.J.; GALLO, P.B.; RAZERA, L.F.; BORTOLETTO, N.; IGUE, T.; MEDINA, P.F.; TISSELLI FILHO, O.; AQUILERA, V.; VEIGA, R.F.A.; PINHEIRO, J.B. Mechanisms of resistance to stink bug complex in the soybean cultivar IAC-100. Anais da Sociedade Entomológica do Brasil, v.24, n.3, p.517-522, 1995.

ROSSETO, C.J.; TISSELLI FILHO, O.; RAZERA, L.F.; GALLO, P.B.; PEDRO JR., M.J.; CAMARGO, M.B.P.; IGUE, T.; TEIXEIRA, J.P.F. Integration of resistant cultivar and date of planting for cultivation of soybean with reduced use of insecticides. In: WORLD SOYBEAN RESEARCH CONFERENCE, IV. Proceedings. Argentina: Buenos Aires, 1989. p.15821588. 
ROSSI, C.; PADILHA, P.M.; PADILHA, C.C.F. Absorção de Cádmio e crescimento de feijoeiro (Phaseolus vulgaris, L. cV carioca). Scientia Agricola, Piracicaba, v.55, n.2, p.332-337, 1998.

RUIZ, W.F.R. Atividades de superóxido dismutase, catalases e peroxidase durante o desenvolvimento de micorrizas arbusculares em feijoeiro, sob condições de baixo e alto nível de fosfato. Piracicaba, 1998. 50p. Dissertação (M.S.) - Escola Superior de Agricultura "Luiz de Queiroz" , Universidade de São Paulo.

SAIRAM, R.K.; DESHMUKH, P.S.; SAXENA, D.C. Role of antioxidant systems in wheat genotypes tolerance to water stress. Biologia Plantarum, v.41, n.3, p.387-394, 1998.

SAKAKI, T. Photochemical oxidants: Toxicity. In: DE KOK, L.J.; STULEN, I. (Ed.) Responses of plant metabolism to air pollution and global change. Leiden, The Netherlands: Backhuys Publishers, 1998. p.117-129.

SALT, D. E.; PRINCE, R. C.; PICKERING, I. J.; RASKIN, I. Mechanisms of cadmium mobility and accumulation in indian mustard. Plant Physiology, v.109, p.1427-1433, 1995.

SANDERMANN, H.; ERNEST, Jr. D.; HELLER, W.; LANGEBARTELS, C. Ozone: an abiotic elicitor of plant defence reactions. Trends in Plant Science, v.3, n.2, p.47-50, 1998.

SCANDALIOS, J.G. Oxygen stress and superoxide dismutases. Plant Physiology, v.101, p.7-12, 1993. 
SCEBBA, F.; SEBASTIANI, L.; VITAGLIANO, C. Changes in activity of antioxidative enzymes in wheat (Triticum aestivum) seedlings under cold acclimation. Physiologia Plantarum, v.104, p.747-752, 1998.

SCHICKLER, H.; CASPI, H. Response of antioxidative enzymes to nickel and cadmium stress in hyperaccumulator plants of the genus Alyssum. Physiologia Plantarum, v.105, p.39-44, 1999.

SEHMER, L.; DIZENGREMEL, P. Contribution to subcellular localization of superoxide dismutase isoforms of spruce needles and oak leaves. Journal of Plant Physiology, v.153, p.545-551, 1998.

SEPPÄNEN, M.M.; MAJAHARJU, M.; SOMERSALO, S.; PEHU, E. Freezing tolerance, cold acclimation and oxidative stress in potato. Paraquat tolerance is related to acclimation but is a poor indicator of freezing tolerance. Physiologia Plantarum, v.102, p.454-460, 1998.

SHALATA, A.; TAL, M. The effect of salt stress on lipid peroxidation and antioxidants in the leaf of the cultivated tomato and its wild salt-tolerant relative Lycopersicon pennellii. Physiologia Plantarum, v.104, p.169-174, 1998.

SIEDLECKA, A.; KRUPA, Z. Cd/Fe interaction in higher plants - its consequences for the photosynthetic apparatus. Photosynthetica, v.36, n.3, p.321-331, 1999.

SKADSEN, R.W.; SCHULZE-LEFERT, P.; HERBST, J.M. Molecular cloning, characterization and expression analysis of two catalase isozyme genes in barley. Plant Molecular Biology, v.29, p.1005-1014, 1995. 
SUNG, J.M. Lipid peroxidation and peroxide-scavenging in soybean seeds during aging. Physiologia Plantarum, v.97, p.85-89, 1996.

TENHAKEN, R.; RÜBEL, C. Salicylic acid is needed in hypersensitive cell death in soybean but does not act as a catalase inhibitor. Plant Physiology, v.115, p.291-298, 1997.

TODOROV, D.; ALEXIEVA, V.; KARANOV, E. Effect of putrescine, 4-PU-30, and abscisic acid on maize plants grown under normal, drought, and rewatering conditions. Journal of Plant Growth Regulation, v.17, p.197203, 1998.

TUKENDORF, A.; SKÓRZYNSKA-POLIT, E.; BASZYNSKI, T. Homophytochelatin accumulation in Cd-treated runner bean plants is related to their growth stage. Plant Science, v.129, p.21-28, 1997.

VALLEJOS, C.E. Enzyme activity staining. In: TANKSLEY, S.D.; ORTON, T.J. (Ed.) Isozymes in plant genetics and breeding, part A. Amsterdam; Oxford; New York: Elsevier, 1983. p.469-516.

VAN HUYLENBROECK, J.M.; VAN LAERE, I.M.B.; PIQUERAS, A.; DEBERGH, P.C.; BUENO, P. Time course of catalase and superoxide dismutase during acclimatization and growth of micropropagated Calathea and Spathiphyllum plants. Plant Growth Regulation, v.26, p.7-14, 1998.

VANACKER, H.; CARVER, T.L.W.; FOYER, C.H. Pathogen-induced changes in the antioxidant status of the apoplast in barley leaves. Plant Physiology, v.117, p.1103-1114, 1998. 
VITÓRIA, A.P.; SMITH, R.J.; LEA, P.J.; AZEVEDO, R.A. Antioxidant enzymes responses to cadmium in radish tissues. Fitochemistry, 2000 (Submetido).

VOET, D.; VOET, J.G. Biochemistry. 2.ed. New York; Chichester; Brisbane; Toronto; Singapore: Wiley, 1995. 1361p.

VÖGELI-LANGE, R.; WAGNER, G. J. Relationship between cadmium, glutathione and cadmium-binding peptides (phytochelatins) in leaves of intact tobacco seedlings. Plant Science, v.114, p.11-18, 1996.

VÖGELI-LANGE, R.; WAGNER, G.J. Subcellular localization of cadmium and cadmium-binding peptides in Tobacco leaves. Plant Physiology, v.92, p.1086-1093, 1990.

WADA, H.; KOSHIBA, T.; MATSUI, T.; SATÓ, M. Involvement of peroxidase in differential sensitivity to $\gamma$-radiation in seedlings of two Nicotiana species. Plant Science, v.132, p.109-119, 1998.

WAGNER, G.L. Accumulation of cadmium in crop plants and its consequences to human health. Advances in Agronomy, v.51, p.173-212, 1993.

WILLEKENS, H.; INZÉ, D.; VAN MONTAGU, M.; VAN CAMP, W. Catalases in plants. Molecular breeding, v.1, p.207-228, 1995.

WINGSLE, G.; GARDESTRÖM, P.; HÄLLGREN, J.; KARPINSKI, S. Isolation, purification, and subcellular localization of isozymes of superoxide dismutase from scots pine (Pinus sylvestris L.) needles. Plant Physiology, v.95, p.2128, 1991. 
WOODBURY, W.; SPENCER, A.K.; STAHMANN, M.A. An improved procedure using ferrycianide for detecting catalase isosymes. Analytical Biochemistry, v.44, n.1, p.301-305, 1971.

YAN, B.; DAI, Q.; LIU, X.; HUANG, S.; WANG, Z. Flooding-induced membrane damage, lipid oxidation and activated oxygen generation in corn leaves. Plant and Soil, v.179, p.261-268, 1996. 